Cochrane Database of Systematic Reviews

\title{
Interventions to increase tuberculosis case detection at primary healthcare or community-level services (Review)
}

Mhimbira FA, Cuevas LE, Dacombe R, Mkopi A, Sinclair D

Mhimbira FA, Cuevas LE, Dacombe R, Mkopi A, Sinclair D.

Interventions to increase tuberculosis case detection at primary healthcare or community-level services.

Cochrane Database of Systematic Reviews 2017, Issue 11. Art. No.: CD011432.

DOI: 10.1002/14651858.CD011432.pub2.

www.cochranelibrary.com

Interventions to increase tuberculosis case detection at primary healthcare or community-level services (Review) 
TABLE OF CONTENTS

ABSTRACT

PLAIN LANGUAGE SUMMARY

SUMMARY OF FINDINGS

BACKGROUND

Figure 1.

OBJECTIVES

METHODS

RESULTS

Figure 2.

Figure 3.

DISCUSSION

AUTHORS' CONCLUSIONS

ACKNOWLEDGEMENTS

REFERENCES

CHARACTERISTICS OF STUDIES

DATA AND ANALYSES

Analysis 1.1. Comparison 1 Outreach tuberculosis screening versus no intervention, Outcome 1 Tuberculosis cases detected (microbiologically confirmed).

Analysis 1.2. Comparison 1 Outreach tuberculosis screening versus no intervention, Outcome 2 Tuberculosis cases detected: subgrouped by tuberculosis prevalence.

Analysis 1.3. Comparison 1 Outreach tuberculosis screening versus no intervention, Outcome 3 Tuberculosis cases detected; subgrouped by intervention.

Analysis 1.4. Comparison 1 Outreach tuberculosis screening versus no intervention, Outcome 4 Tuberculosis cases detected (all forms).

Analysis 1.5. Comparison 1 Outreach tuberculosis screening versus no intervention, Outcome 5 Tuberculosis treatment default.

Analysis 1.6. Comparison 1 Outreach tuberculosis screening versus no intervention, Outcome 6 Tuberculosis treatment success.

Analysis 1.7. Comparison 1 Outreach tuberculosis screening versus no intervention, Outcome 7 Tuberculosis treatment failure.

Analysis 1.8. Comparison 1 Outreach tuberculosis screening versus no intervention, Outcome 8 Tuberculosis mortality. ......... Analysis 1.9. Comparison 1 Outreach tuberculosis screening versus no intervention, Outcome 9 Long-term tuberculosis prevalence.

Analysis 2.1. Comparison 2 Health promotion activities compared to no intervention, Outcome 1 Long-term tuberculosis prevalence.

Analysis 3.1. Comparison 3 Training interventions compared to intervention, Outcome 1 Tuberculosis cases detected (microbiologically confirmed).

Analysis 4.1. Comparison 4 Outreach tuberculosis services versus health promotion, Outcome 1 Tuberculosis cases detected (microbiologically confirmed).

Analysis 5.1. Comparison 5 Outreach clinic versus house-to-house screening, Outcome 1 Tuberculosis cases detected (microbiologically confirmed).

Analysis 6.1. Comparison 6 Active case-finding interventions versus no intervention, Outcome 1 Tuberculosis cases detected (microbiologically confirmed).

Analysis 6.2. Comparison 6 Active case-finding interventions versus no intervention, Outcome 2 Tuberculosis cases detected: subgrouped by tuberculosis prevalence.

Analysis 6.3. Comparison 6 Active case-finding interventions versus no intervention, Outcome 3 Tuberculosis cases detected; subgrouped by intervention.

Analysis 6.4. Comparison 6 Active case-finding interventions versus no intervention, Outcome 4 Long-term tuberculosis prevalence: subgrouped by intervention.

Analysis 6.5. Comparison 6 Active case-finding interventions versus no intervention, Outcome 5 Tuberculosis treatment success.

Analysis 6.6. Comparison 6 Active case-finding interventions versus no intervention, Outcome 6 Tuberculosis treatment default. 
Analysis 6.7. Comparison 6 Active case-finding interventions versus no intervention, Outcome 7 Tuberculosis treatment failure.

Analysis 6.8. Comparison 6 Active case-finding interventions versus no intervention, Outcome 8 Tuberculosis mortality. ........ Analysis 6.9. Comparison 6 Active case-finding interventions versus no intervention, Outcome 9 People with tuberculosis detected.

Analysis 7.1. Comparison 7 Outreach tuberculosis services versus no intervention (sensitivity analyses), Outcome 1 Tuberculosis cases detected (microbiologically confirmed).

Analysis 7.2. Comparison 7 Outreach tuberculosis services versus no intervention (sensitivity analyses), Outcome 2 Tuberculosis cases detected: subgrouped by tuberculosis prevalence.

Analysis 7.3. Comparison 7 Outreach tuberculosis services versus no intervention (sensitivity analyses), Outcome 3 Tuberculosis cases detected; subgrouped by intervention.

Analysis 7.4. Comparison 7 Outreach tuberculosis services versus no intervention (sensitivity analyses), Outcome 4 Tuberculosis cases detected (all forms).

Analysis 7.5. Comparison 7 Outreach tuberculosis services versus no intervention (sensitivity analyses), Outcome 5 Tuberculosis treatment default.

Analysis 7.6. Comparison 7 Outreach tuberculosis services versus no intervention (sensitivity analyses), Outcome 6 Tuberculosis treatment success.

Analysis 7.7. Comparison 7 Outreach tuberculosis services versus no intervention (sensitivity analyses), Outcome 7 Tuberculosis treatment failure.

Analysis 7.8. Comparison 7 Outreach tuberculosis services versus no intervention (sensitivity analyses), Outcome 8 Tuberculosis mortality.

Analysis 7.9. Comparison 7 Outreach tuberculosis services versus no intervention (sensitivity analyses), Outcome 9 Long-term tuberculosis prevalence.

ADDITIONAL TABLES

APPENDICES

CONTRIBUTIONS OF AUTHORS

DECLARATIONS OF INTEREST

SOURCES OF SUPPORT

DIFFERENCES BETWEEN PROTOCOL AND REVIEW

INDEX TERMS 
[Intervention Review]

\title{
Interventions to increase tuberculosis case detection at primary healthcare or community-level services
}

\author{
Francis A Mhimbira1,2,3, Luis E. Cuevas ${ }^{4}$, Russell Dacombe ${ }^{5}$, Abdallah Mkopi6, David Sinclair4
}

1Bagamoyo Research and Training Center (BRTC), Ifakara Health Institute (IHI), Bagamoyo, Tanzania. 2Swiss Tropical and Public Health Institute, Basel, Switzerland. ${ }^{3}$ University of Basel, Basel, Switzerland. ${ }^{4}$ Department of Clinical Sciences, Liverpool School of Tropical Medicine, Liverpool, UK. 5 Department of International Public Health, Liverpool School of Tropical Medicine, Liverpool, UK. 6 Impact Evaluation, Health Systems Interventions \& Policy Translation, Ifakara Health Institute (IHI), Dar es Salaam, Tanzania

Contact: Francis A Mhimbira, Bagamoyo Research and Training Center (BRTC), Ifakara Health Institute (IHI), PO Box 74, Bagamoyo, Tanzania.fmhimbira@ihi.or.tz.

Editorial group: Cochrane Infectious Diseases Group.

Publication status and date: Unchanged, published in Issue 11, 2017.

Citation: Mhimbira FA, Cuevas LE, Dacombe R, Mkopi A, Sinclair D. Interventions to increase tuberculosis case detection at primary healthcare or community-level services. Cochrane Database of Systematic Reviews 2017, Issue 11. Art. No.: CD011432. DOI: 10.1002/14651858.CD011432.pub2.

Copyright (c) 2017 The Authors. Cochrane Database of Systematic Reviews published by John Wiley \& Sons, Ltd. on behalf of The Cochrane Collaboration. This is an open access article under the terms of the Creative Commons Attribution-Non-Commercial Licence, which permits use, distribution and reproduction in any medium, provided the original work is properly cited and is not used for commercial purposes.

\section{A B S T R A C T}

\section{Background}

Pulmonary tuberculosis is usually diagnosed when symptomatic individuals seek care at healthcare facilities, and healthcare workers have a minimal role in promoting the health-seeking behaviour. However, some policy specialists believe the healthcare system could be more active in tuberculosis diagnosis to increase tuberculosis case detection.

\section{Objectives}

To evaluate the effectiveness of different strategies to increase tuberculosis case detection through improving access (geographical, financial, educational) to tuberculosis diagnosis at primary healthcare or community-level services.

\section{Search methods}

We searched the following databases for relevant studies up to 19 December 2016: the Cochrane Infectious Disease Group Specialized Register; the Cochrane Central Register of Controlled Trials (CENTRAL), published in the Cochrane Library, Issue 12, 2016; MEDLINE; Embase; Science Citation Index Expanded, Social Sciences Citation Index; BIOSIS Previews; and Scopus. We also searched the World Health Organization International Clinical Trials Registry Platform (WHO ICTRP), ClinicalTrials.gov, and the metaRegister of Controlled Trials (mRCT) for ongoing trials.

\section{Selection criteria}

Randomized and non-randomized controlled studies comparing any intervention that aims to improve access to a tuberculosis diagnosis, with no intervention or an alternative intervention.

\section{Data collection and analysis}

Two review authors independently assessed trials for eligibility and risk of bias, and extracted data. We compared interventions using risk ratios (RR) and 95\% confidence intervals (CI). We assessed the certainty of the evidence using the GRADE approach. 


\section{Main results}

We included nine cluster-randomized trials, one individual randomized trial, and seven non-randomized controlled studies. Nine studies were conducted in sub-Saharan Africa (Ethiopia, Nigeria, South Africa, Zambia, and Zimbabwe), six in Asia (Bangladesh, Cambodia, India, Nepal, and Pakistan), and two in South America (Brazil and Colombia); which are all high tuberculosis prevalence areas.

Tuberculosis outreach screening, using house-to-house visits, sometimes combined with printed information about going to clinic, may increase tuberculosis case detection (RR 1.24, 95\% Cl 0.86 to 1.79; 4 trials, 6,458,591 participants in 297 clusters, low-certainty evidence); and probably increases case detection in areas with tuberculosis prevalence of $5 \%$ or more (RR $1.52,95 \% \mathrm{Cl} 1.10$ to $2.09 ; 3$ trials, 155,918 participants, moderate-certainty evidence; prespecified stratified analysis). These interventions may lower the early default (prior to starting treatment) or default during treatment (RR $0.67,95 \% \mathrm{Cl} 0.47$ to $0.96 ; 3$ trials, 849 participants, low-certainty evidence). However, this intervention may have may have little or no effect on treatment success (RR 1.07, 95\% $\mathrm{Cl} 1.00$ to $1.15 ; 3$ trials, 849 participants, lowcertainty evidence), and we do not know if there is an effect on treatment failure or mortality. One study investigated long-term prevalence in the community, but with no clear effect due to imprecision and differences in care between the two groups ( $\mathrm{RR} 1.14,95 \% \mathrm{Cl} 0.65$ to 2.00 ; 1 trial, 556,836 participants, very low-certainty evidence).

Four studies examined health promotion activities to encourage people to attend for screening, including mass media strategies and more locally organized activities. There was some increase, but this could have been related to temporal trends, with no corresponding increase in case notifications, and no evidence of an effect on long-term tuberculosis prevalence. Two studies examined the effects of two to six nurse practitioner educational sessions in tuberculosis diagnosis, with no clear effect on tuberculosis cases detected. One trial compared mobile clinics every five days with house-to-house screening every six months, and showed an increase in tuberculosis cases.

There was also insufficient evidence to determine if sustained improvements in case detection impact on long-term tuberculosis prevalence; this was evaluated in one study, which indicated little or no effect after four years of either contact tracing, extensive health promotion activities, or both (RR 1.31, 95\% $\mathrm{Cl} 0.75$ to 2.30; 1 study, 405,788 participants in 12 clusters, very low-certainty evidence).

\section{Authors' conclusions}

The available evidence demonstrates that when used in appropriate settings, active case-finding approaches may result in increase in tuberculosis case detection in the short term. The effect of active case finding on treatment outcome needs to be further evaluated in sufficiently powered studies.

2 April 2019

Up to date

All studies incorporated from most recent search

All eligible published studies found in the last search (19 Dec, 2016) were included

\section{PLAIN LANGUAGE SUMMARY}

\section{Interventions to increase the number of tuberculosis cases being diagnosed}

This review summarized trials evaluating the effects of interventions aiming to increase the diagnosis of tuberculosis and reduce the number of undiagnosed tuberculosis cases in communities. After searching for relevant trials up to 19 December 2016, we included 17 studies conducted in sub-Saharan Africa (nine studies), Asia (six studies), and South America (two studies).

\section{Why does tuberculosis go undiagnosed and how might programmes improve this?}

Tuberculosis is a chronic infectious disease that affects over 10 million people worldwide, with an estimated four million tuberculosis patients remaining undiagnosed each year. Interventions such as outreach tuberculosis screening with or without health promotion that actively screen for tuberculosis among individuals presenting with symptoms of tuberculosis, may increase detection of microbiologically confirmed tuberculosis cases. These interventions may improve treatment outcomes by increasing the number of tuberculosis patients who are cured and complete treatment. However, we do not know if these interventions reduce either tuberculosis treatment failure, or tuberculosis-associated death or long-term tuberculosis burden in moderate- and high-tuberculosis settings.

\section{What the research says}

House-to-house screening for active tuberculosis, and organizing tuberculosis diagnostic clinics nearer to where people live and work, may increase tuberculosis case detection in settings where the prevalence of undiagnosed disease is high (low-certainty evidence). These people may have higher levels of treatment success and lower levels of default from treatment (low-certainty evidence).

There was insufficient evidence to determine if health promotion activities alone increase tuberculosis case detection (very low-certainty evidence). 
There was also insufficient evidence to determine if sustained improvements in case detection impact on long-term tuberculosis prevalence, as the only study to evaluate this found no effect after four years (very low-certainty evidence). 


\section{SUMMARY OF FINDINGS}

\section{Summary of findings for the main comparison. Tuberculosis outreach screening versus no intervention}

Tuberculosis outreach screening (with or without health promotion) to encourage presumptive tuberculosis patients to attend health services

\section{Patient or population: all age groups}

Settings: countries with moderate or high tuberculosis prevalence (> 10 tuberculosis cases per 100,000 population per year)

Intervention: tuberculosis outreach screening with and without health promotion activities

Comparison: no screening

Trial design: cluster-RCTs only (non-randomized studies are commented on in the footnotes)

\begin{tabular}{|c|c|c|c|c|c|c|}
\hline \multirow[t]{3}{*}{ Outcomes } & \multicolumn{2}{|c|}{$\begin{array}{l}\text { Illustrative comparative risks }{ }^{\star} \\
(95 \% \mathrm{CI})\end{array}$} & \multirow[t]{3}{*}{$\begin{array}{l}\text { Relative effect } \\
(95 \% \mathrm{CI})\end{array}$} & \multirow{3}{*}{$\begin{array}{l}\text { Number of partici- } \\
\text { pants } \\
\text { (studies) }\end{array}$} & \multirow{3}{*}{$\begin{array}{l}\text { Certainty of the evi- } \\
\text { dence } \\
\text { (GRADE) }\end{array}$} & \multirow[t]{3}{*}{ Comments } \\
\hline & Assumed risk & $\begin{array}{l}\text { Corresponding } \\
\text { risk }\end{array}$ & & & & \\
\hline & $\begin{array}{l}\text { No interven- } \\
\text { tion }\end{array}$ & $\begin{array}{l}\text { Tuberculosis } \\
\text { outreach screen- } \\
\text { ing } \pm \text { health pro- } \\
\text { motion }\end{array}$ & & & & \\
\hline $\begin{array}{l}\text { Tuberculosis } \\
\text { cases detect- } \\
\text { ed (microbio- } \\
\text { logically con- } \\
\text { firmed) }\end{array}$ & 90 per 100,000 & $\begin{array}{l}112 \text { per } 100,000 \\
\text { ( } 77 \text { to } 161 \text { ) }\end{array}$ & $\begin{array}{l}\text { RR } 1.24 \text { ( } 0.86 \text { to } \\
1.79)\end{array}$ & $\begin{array}{l}\text { 163,043 partici- } \\
\text { pants } \\
\text { in } 297 \text { clusters } \\
\text { (4 studies) }\end{array}$ & $\begin{array}{l}\text { low } 1,2,3,4 \\
\text { due to imprecision } \\
\text { and inconsistency }\end{array}$ & $\begin{array}{l}\text { Screening with health promotion may in- } \\
\text { crease the number of microbiologically con- } \\
\text { firmed people with tuberculosis. }\end{array}$ \\
\hline $\begin{array}{l}\text { Default within } \\
\text { first } 2 \text { months }\end{array}$ & 16 per 100 & $\begin{array}{l}12 \text { per } 100 \\
\text { (8 to } 15)\end{array}$ & $\begin{array}{l}\text { RR } 0.67 \\
(0.47 \text { to } 0.96)\end{array}$ & $\begin{array}{l}849 \text { patients } \\
\text { ( } 3 \text { cluster-RCTs) }\end{array}$ & $\begin{array}{l}\text { low } 1,2,5 \\
\text { due to imprecision }\end{array}$ & $\begin{array}{l}\text { Screening with health promotion may reduce } \\
\text { default prior to and at the first } 2 \text { months of tu- } \\
\text { berculosis treatment. }\end{array}$ \\
\hline $\begin{array}{l}\text { Treatment suc- } \\
\text { cess }\end{array}$ & 78 per 100 & $\begin{array}{l}83 \text { per } 100 \\
\text { (78 to } 90)\end{array}$ & $\begin{array}{l}\text { RR } 1.07 \\
\text { (1.00 to } 1.15 \text { ) }\end{array}$ & $\begin{array}{l}849 \text { patients } \\
\text { ( } 3 \text { cluster-RCTs) }\end{array}$ & $\begin{array}{l}\text { low } 1,6,7 \\
\text { due to imprecision } \\
\text { and indirectness }\end{array}$ & $\begin{array}{l}\text { Screening with health promotion may have } \\
\text { little or no effect on treatment success. }\end{array}$ \\
\hline $\begin{array}{l}\text { Treatment fail- } \\
\text { ure }\end{array}$ & 1.3 per 100 & $\begin{array}{l}2.0 \text { per } 100 \\
(0.3 \text { to } 6.4)\end{array}$ & $\begin{array}{l}\text { RR } 1.57 \\
\text { (0.50 to } 4.92 \text { ) }\end{array}$ & $\begin{array}{l}849 \text { patients } \\
\text { ( } 3 \text { cluster-RCTs) }\end{array}$ & very low $1,2,5,8$ & $\begin{array}{l}\text { We do not know if screening with health pro- } \\
\text { motion influences treatment failure. }\end{array}$ \\
\hline
\end{tabular}




\begin{tabular}{|c|c|c|c|c|c|c|}
\hline $\begin{array}{l}\text { Tuberculosis } \\
\text { mortality }\end{array}$ & 3 per 100 & $\begin{array}{l}3 \text { per } 100 \\
(1.3 \text { to } 6.75)\end{array}$ & $\begin{array}{l}\text { RR } 0.99 \\
\text { (0.43 to } 2.25)\end{array}$ & $\begin{array}{l}849 \text { patients } \\
\text { ( } 3 \text { cluster-RCTs) }\end{array}$ & $\begin{array}{l}\text { low } 1,2,3,5 \\
\text { due to imprecision }\end{array}$ & $\begin{array}{l}\text { Screening with health promotion may have } \\
\text { little or no effect on mortality. }\end{array}$ \\
\hline $\begin{array}{l}\text { Long-term } \\
\text { tuberculosis } \\
\text { prevalence }\end{array}$ & 773 per 100,000 & $\begin{array}{l}881 \text { per } 100,000 \\
(502 \text { to } 1546)\end{array}$ & $\begin{array}{l}\text { RR } 1.14 \\
\text { (0.65 to } 2.00)\end{array}$ & $\begin{array}{l}556,836 \text { partici- } \\
\text { pants } \\
\text { in } 12 \text { clusters } \\
\text { ( } 1 \text { cluster-RCT) }\end{array}$ & $\begin{array}{l}\text { very low } 1,2,7,8 \\
\text { due to imprecision } \\
\text { and indirectness }\end{array}$ & $\begin{array}{l}\text { We do not know if screening with health pro- } \\
\text { motion influences treatment failure. }\end{array}$ \\
\hline
\end{tabular}

The basis for the assumed risk is the median control group risk across studies. The corresponding risk (and its $95 \% \mathrm{Cl}$ ) is based on the assumed risk in the comparison group and the relative effect of the intervention (and its $95 \% \mathrm{CI}$ ).

Abbreviations: $\mathrm{Cl}$ : confidence interval; RCT: randomized controlled trial; RR: risk ratio

GRADE Working Group grades of evidence

High certainty: further research is very unlikely to change our confidence in the estimate of effect.

Moderate certainty: further research is likely to have an important impact on our confidence in the estimate of effect and may change the estimate.

Low certainty: further research is very likely to have an important impact on our confidence in the estimate of effect and is likely to change the estimate.

Very low certainty: We are very uncertain about the estimate.

${ }^{1}$ No serious risk of bias: the studies were generally at low risk of bias. Not downgraded.

${ }^{2}$ No serious indirectness. The studies were done in high-prevalent tuberculosis settings in Africa (3) and Asia (1). The results could be generalized to other countries with similar tuberculosis burden and socioeconomic profile.

${ }^{3}$ Downgraded once for serious inconsistency. One study done in South Africa showed that the intervention detected fewer tuberculosis cases compared to no intervention. This cluster-RCT had fewer participants recruited from the farmers, who may have a different risk profile compared to the general population and different from the other three clusterRCTs. However, in a prespecified subgroup analysis by background tuberculosis endemicity in studies conducted in areas with a prevalence of $5 \%$ or more, heterogeneity was explained and the estimate became more precise (RR $1.52,95 \% \mathrm{Cl} 1.10$ to $2.09,3$ trials, 155,918 participants, moderate-certainty evidence).

${ }^{4}$ Downgraded once for serious imprecision. The $95 \% \mathrm{Cl}$ includes both clinically important effects and no difference for the effect of the intervention compared to control.

${ }^{5}$ Downgraded twice for serious imprecision. The $95 \% \mathrm{Cl}$ is wide and includes both clinically important effects and no difference for the effect of the intervention compared to control. The imprecision of the results could be due to small numbers of tuberculosis patients and number of tuberculosis patients with the outcome of interest. The studies were not powered enough to detect a difference between groups for the tuberculosis treatment outcomes.

${ }^{6}$ Downgraded once for serious imprecision. The $95 \% \mathrm{Cl}$ includes no difference for the effect of the intervention compared to the control group. The imprecision of the results could be due to small numbers of tuberculosis patients and number of tuberculosis patients with the outcome of interest.

${ }^{7}$ Downgraded twice for serious imprecision.

${ }^{8}$ Downgraded once for serious indirectness. The intervention arms had additional staff and procedures for following up patients on treatment. This may have a paradoxical effect of detecting more people who have treatment failure. 


\begin{tabular}{|c|c|c|c|c|c|c|}
\hline \multicolumn{7}{|c|}{ Health promotion activities to encourage people with symptoms of tuberculosis to attend health services } \\
\hline \multicolumn{7}{|c|}{$\begin{array}{l}\text { Patient or population: all age groups } \\
\text { Settings: areas with moderate or high tuberculosis prevalence } \\
\text { Intervention: health promotion activities alone } \\
\text { Comparison: no intervention }\end{array}$} \\
\hline \multirow[t]{3}{*}{ Outcomes } & \multicolumn{2}{|c|}{$\begin{array}{l}\text { Illustrative comparative risks }{ }^{\star}(95 \% \\
\mathrm{Cl})\end{array}$} & \multirow[t]{3}{*}{$\begin{array}{l}\text { Relative effect } \\
(95 \% \mathrm{CI})\end{array}$} & \multirow{3}{*}{$\begin{array}{l}\text { Number of par- } \\
\text { ticipants } \\
\text { (studies) }\end{array}$} & \multirow{3}{*}{$\begin{array}{l}\text { Certainty of the } \\
\text { evidence } \\
\text { (GRADE) }\end{array}$} & \multirow[t]{3}{*}{ Comments } \\
\hline & Assumed risk & Corresponding risk & & & & \\
\hline & $\begin{array}{l}\text { No interven- } \\
\text { tion }\end{array}$ & Health promotion & & & & \\
\hline $\begin{array}{l}\text { Long-term tuberculosis prevalence } \\
\text { (assessed at } 4 \text { years) }\end{array}$ & 773 per 100,000 & $\begin{array}{l}1012 \text { per } 100,000 \\
\text { (580 to } 1778)\end{array}$ & $\begin{array}{l}\text { RR } 1.31 \\
\text { (0.75 to } 2.30\end{array}$ & $\begin{array}{l}405,788 \text { in } 12 \\
\text { clusters } \\
\text { (1 cluster-RCT) }\end{array}$ & very low $1,2,3,4$ & $\begin{array}{l}\text { We do not know if } \\
\text { health promotion } \\
\text { reduces long-term } \\
\text { tuberculosis preva- } \\
\text { lence. }\end{array}$ \\
\hline Treatment success & - & - & - & - & (0 studies) & - \\
\hline Tuberculosis mortality & - & - & - & - & (0 studies) & - \\
\hline Long-term tuberculosis prevalence & - & - & - & - & (0 studies) & - \\
\hline
\end{tabular}

*The basis for the assumed risk (for example, the median control group risk across studies) is provided in footnotes. The corresponding risk (and its $95 \% \mathrm{Cl}$ ) is based on the assumed risk in the comparison group and the relative effect of the intervention (and its $95 \% \mathrm{Cl}$ ).

Abbreviations: Cl: confidence interval; RCT: randomized controlled trial; RR: risk ratio

GRADE Working Group grades of evidence

High certainty: further research is very unlikely to change our confidence in the estimate of effect.

Moderate certainty: further research is likely to have an important impact on our confidence in the estimate of effect and may change the estimate.

Low certainty: further research is very likely to have an important impact on our confidence in the estimate of effect and is likely to change the estimate.

Very low certainty: We are very uncertain about the estimate.

${ }^{1}$ No serious risk of bias: only one study is included and it warrants no downgrading.

2 No serious inconsistency; it is the only cluster-randomized trial. 
3Downgraded twice for serious indirectness: this is a single study from Zambia and South Africa, with prevalence measured at four years. It does not exclude the possibility of effects in different settings, or at later time points.

${ }^{4}$ Downgraded once for serious imprecision: the $95 \% \mathrm{Cl}$ is wide and includes both clinically important effects and no difference.

\section{Summary of findings 3. Training interventions compared to no intervention}

\section{Health staff training in tuberculosis diagnosis}

Patient or population: all age groups

Settings: areas with moderate or high tuberculosis prevalence

Intervention: health staff training activities

Comparison: no intervention

\begin{tabular}{|c|c|c|c|c|c|c|}
\hline \multirow[t]{3}{*}{ Outcomes } & \multicolumn{2}{|c|}{$\begin{array}{l}\text { Illustrative comparative risks }{ }^{\star}(95 \% \\
\mathrm{CI})\end{array}$} & \multirow[t]{3}{*}{$\begin{array}{l}\text { Relative effect } \\
(95 \% \mathrm{Cl})\end{array}$} & \multirow[t]{3}{*}{$\begin{array}{l}\text { Number of participants } \\
\text { (studies) }\end{array}$} & \multirow{3}{*}{$\begin{array}{l}\text { Certainty of } \\
\text { the evidence } \\
\text { (GRADE) }\end{array}$} & \multirow[t]{3}{*}{ Comments } \\
\hline & Assumed risk & $\begin{array}{l}\text { Corresponding } \\
\text { risk }\end{array}$ & & & & \\
\hline & $\begin{array}{l}\text { No interven- } \\
\text { tion }\end{array}$ & Health promotion & & & & \\
\hline Treatment success & - & - & - & (0 studies) & - & - \\
\hline Tuberculosis mortality & - & - & - & (0 studies) & - & - \\
\hline
\end{tabular}

*The basis for the assumed risk (for example, the median control group risk across studies) is provided in footnotes. The corresponding risk (and its $95 \% \mathrm{Cl}$ ) is based on the assumed risk in the comparison group and the relative effect of the intervention (and its $95 \% \mathrm{Cl}$ ).

Abbreviations: $\mathrm{Cl}$ : confidence interval; RR: risk ratio.

GRADE Working Group grades of evidence

High certainty: further research is very unlikely to change our confidence in the estimate of effect.

Moderate certainty: further research is likely to have an important impact on our confidence in the estimate of effect and may change the estimate. 


\begin{tabular}{|c|c|c|c|c|c|c|}
\hline \multicolumn{7}{|c|}{$\begin{array}{l}{ }^{1} \text { No serious risk of bias: only one study is included and it warrants no downgrading. } \\
\text { 2No serious inconsistency; it is the only cluster-randomized trial. } \\
\text { 3Downgraded twice for serious indirectness: this is a single study from South Africa. } \\
{ }^{4} \text { No serious imprecision. } \\
\text { Summary of findings 4. Outreach tuberculosis screening versus health }\end{array}$} \\
\hline \multicolumn{7}{|c|}{ Outreach tuberculosis screening versus health promotion } \\
\hline \multicolumn{7}{|c|}{$\begin{array}{l}\text { Patient or population: adults } \\
\text { Settings: areas with moderate or high tuberculosis prevalence } \\
\text { Intervention 1: mobile clinic situated in each cluster for } 5 \text { days every } 6 \text { months with associated leafleting and loudspeaker } \\
\text { Intervention 2: house-to-house screening every } 6 \text { months }\end{array}$} \\
\hline \multirow[t]{3}{*}{ Outcomes } & \multicolumn{2}{|c|}{$\begin{array}{l}\text { Illustrative comparative risks* }(95 \% \\
\mathrm{CI})\end{array}$} & \multirow[t]{3}{*}{$\begin{array}{l}\text { Relative effect } \\
(95 \% \mathrm{Cl})\end{array}$} & \multirow{3}{*}{$\begin{array}{l}\text { Number of partici- } \\
\text { pants } \\
\text { (studies) }\end{array}$} & \multirow[t]{3}{*}{$\begin{array}{l}\text { Certainty of } \\
\text { the evidence } \\
\text { (GRADE) }\end{array}$} & \multirow[t]{3}{*}{ Comments } \\
\hline & Assumed risk & $\begin{array}{l}\text { Corresponding } \\
\text { risk }\end{array}$ & & & & \\
\hline & Mobile clinic & House-to-house & & & & \\
\hline $\begin{array}{l}\text { Tuberculosis cases detected } \\
\text { (microbiologically confirmed) }\end{array}$ & 250 per 100,000 & $\begin{array}{l}406 \text { per } 100,000 \\
\text { (317 to } 578 \text { ) }\end{array}$ & $\begin{array}{l}\text { RR } 1.71 \\
\text { (1.27 to } 2.31 \text { ) }\end{array}$ & $\begin{array}{l}110,162 \\
\text { (1 study) }\end{array}$ & very low $1,2,3,4$ & $\begin{array}{l}\text { We do not know if outreach tu- } \\
\text { berculosis screening activities in- } \\
\text { crease the number of microbiolog- } \\
\text { ically confirmed people with tuber- } \\
\text { culosis. }\end{array}$ \\
\hline Treatment success & - & - & - & (0 studies) & - & - \\
\hline Tuberculosis mortality & - & - & - & (0 studies) & - & - \\
\hline $\begin{array}{l}\text { Long-term tuberculosis } \\
\text { prevalence }\end{array}$ & - & - & - & (0 studies) & - & - \\
\hline
\end{tabular}

${ }^{\star}$ The basis for the assumed risk (for example, the median control group risk across studies) is provided in footnotes. The corresponding risk (and its $95 \% \mathrm{Cl}$ ) is based on the assumed risk in the comparison group and the relative effect of the intervention (and its $95 \% \mathrm{CI}$ ). 
GRADE Working Group grades of evidence

High certainty: further research is very unlikely to change our confidence in the estimate of effect.

Moderate certainty: further research is likely to have an important impact on our confidence in the estimate of effect and may change the estimate.

Low certainty: further research is very likely to have an important impact on our confidence in the estimate of effect and is likely to change the estimate.

Very low certainty: We are very uncertain about the estimate.

${ }^{1}$ No serious risk of bias: only one study is included and it warrants no downgrading

2 No serious inconsistency; it is the only cluster-randomized trial.

${ }^{3}$ Downgraded twice for serious indirectness: this is a single study from Brazil.

${ }^{4}$ No serious imprecision.

\section{Summary of findings 5. Outreach clinic versus house-to-house screening}

\section{Outreach clinic compared with house-to-house screening for presumptive tuberculosis patients to test for tuberculosis}

\section{Patient or population: adults}

Settings: high tuberculosis burden setting

\section{Intervention: outreach clinic}

\section{Comparison: house-to-house}

\begin{tabular}{|c|c|c|c|c|c|c|}
\hline \multirow[t]{3}{*}{ Outcomes } & \multicolumn{2}{|c|}{$\begin{array}{l}\text { Illustrative comparative risks }{ }^{\star}(95 \% \\
\mathrm{CI})\end{array}$} & \multirow[t]{3}{*}{$\begin{array}{l}\text { Relative effect } \\
(95 \% \mathrm{CI})\end{array}$} & \multirow[t]{3}{*}{$\begin{array}{l}\text { Number of participants } \\
\text { (studies) }\end{array}$} & \multirow{3}{*}{$\begin{array}{l}\text { Certainty of } \\
\text { the evidence } \\
\text { (GRADE) }\end{array}$} & \multirow[t]{3}{*}{ Comments } \\
\hline & Assumed risk & $\begin{array}{l}\text { Corresponding } \\
\text { risk }\end{array}$ & & & & \\
\hline & $\begin{array}{l}\text { House-to- } \\
\text { house }\end{array}$ & Outreach clinic & & & & \\
\hline $\begin{array}{l}\text { Tuberculosis cases detected (mi- } \\
\text { crobiologically confirmed) }\end{array}$ & 238 per 1000 & $\begin{array}{l}352 \text { per } 1000 \\
(264 \text { to } 469)\end{array}$ & $\begin{array}{l}\text { RR } 1.48 \text { (1.11 to } \\
1.97)\end{array}$ & $\begin{array}{l}\text { 405,819 participants in } \\
46 \text { clusters } \\
\text { (1 study) }\end{array}$ & very low $1,2,3,4$ & $\begin{array}{l}\text { We do not know if out } \\
\text { reach clinic activities } \\
\text { increase tuberculosis } \\
\text { cases detected. }\end{array}$ \\
\hline Treatment success & - & - & - & (0 studies) & - & - \\
\hline Tuberculosis mortality & - & - & - & (0 studies) & - & - \\
\hline
\end{tabular}


High certainty: further research is very unlikely to change our confidence in the estimate of effect.

Moderate certainty: further research is likely to have an important impact on our confidence in the estimate of effect and may change the estimate.

Low certainty: further research is very likely to have an important impact on our confidence in the estimate of effect and is likely to change the estimate.

Very low certainty: We are very uncertain about the estimate.

${ }^{1}$ No serious risk of bias: only one study is included and it warrants no downgrading.

${ }^{2}$ No serious inconsistency; it is only cluster-randomized trial.

${ }^{3}$ Downgraded twice for serious indirectness: this is a single study from Zimbabwe. It does not exclude the possibility of effects in different settings, or at later time points.

${ }^{4}$ No serious imprecision. 


\section{B A C K G R O U N D}

\section{Description of the condition}

Tuberculosis is caused by infection with the bacterium Mycobacterium tuberculosis. In 2015, the World Health Organization (WHO) reported 10.4 million new cases globally, causing 1.8 million deaths (WHO 2016). Africa and Asia are most heavily affected. India, Indonesia, and China contribute over $40 \%$ of the world's tuberculosis cases, and populations in some African countries have the highest rates per capita (WHO 2016).

Pulmonary tuberculosis (infection of the lungs) is the most common form of tuberculosis, as well as the most infectious, as transmission occurs from person-to-person via inhalation of respiratory droplets expelled when coughing or sneezing (Glickman 2001). However, most people who are infected with M. tuberculosis initially develop latent tuberculosis, where the infection is contained by the immune system and the person remains well (Sharma 2012). Active tuberculosis, with the development of symptoms, can occur at any time and is strongly associated with immune system impairment due to illnesses such as HIV, malnutrition, and diabetes (Lönnroth 2009).

The gold-standard test for pulmonary tuberculosis is sputum culture, but as this can take up to eight weeks due to the slow growth of the bacterium, treatment is usually started based on other test results (Parsons 2011). Sputum smear microscopy and Xpert MTB/RIF (a DNA amplification test) are the most commonly used initial tests and may be combined with a chest X-ray (Steingart 2014; WHO 2009). Treatment of drug-sensitive pulmonary tuberculosis requires patients to take a combination of medicines for six to nine months (WHO 2015a), while drug-resistant forms typically require much longer courses.

Guidelines in high-burden countries advise health workers to consider pulmonary tuberculosis in all people with a cough lasting more than two weeks (WHO 2015a). However, most people diagnosed with tuberculosis have been coughing for much longer than this by the time they are tested (Corbett 2009; Hinderaker 2011). People may delay seeking care due to the stigma associated with tuberculosis, uncertainty about the severity of their illness, the distance to health services, the affordability of health services, or poor perceptions of the local quality of care
(Mfinanga 2008). Similarly, health workers may delay diagnosis due to a lack of awareness or training in tuberculosis diagnosis, or the unavailability of appropriate tests (Storla 2008).

\section{Description of the intervention}

Pulmonary tuberculosis is usually diagnosed when symptomatic individuals present to healthcare services. This is termed 'passive case detection', as the health system doesn't play a role in the health-seeking behaviour of the individual. Concerns about delayed diagnosis increasing transmission, and a growing desire to tackle the global epidemic head-on have led to the promotion of more 'active' approaches to seek out early or undiagnosed tuberculosis cases amongst communities (WHO 2011).

Two terms are now used commonly in the literature: 'active casefinding', which is typically interpreted as systematic screening of populations, and 'enhanced case-finding', which is harder to define but typically involves a lower degree of effort (Golub 2005). The interventions included under these terms are highly variable, and often multifaceted, containing elements that reduce multiple barriers to accessing care. For example, programmes that systematically screen households for tuberculosis will typically improve tuberculosis diagnostic skills among health workers (through training), reduce the financial costs of attending health care (by providing the initial screening test at the patient's home), as well as reduce barriers related to patient awareness of their illness and stigma related to the disease. As the barriers to accessing a tuberculosis diagnosis vary considerably between settings, successful programmes will need to both be aware of the local problems and be designed specifically to overcome them.

For the purposes of this Cochrane Review, we considered any intervention aimed at increasing confirmed tuberculosis cases by providing either improved diagnostic services or health promotion activities at primary health care or the community level.

\section{How the intervention might work}

Community-based interventions may initially increase tuberculosis case detection by: 1) identifying people with early tuberculosis who are not yet sufficiently unwell to seek care; or 2) identifying people with advanced tuberculosis who would not have presented to health services of their own accord (Figure 1). 
Figure 1. Logic model showing the additional cases that would never present passively and long-term impact on lowering tuberculosis prevalence and incidence.

Logic model

\begin{tabular}{|c|c|c|c|c|}
\hline Secondary Outcome & Primary Outcome & & Secondary Outcomes & \\
\hline $\begin{array}{l}\text { Intermediate outcome } \\
\text { (proposed mechanism) }\end{array}$ & & Intermediate outcome & TB Treatment Outcomes & Impact Outcomes \\
\hline
\end{tabular}

Intervention
\begin{tabular}{c|c|c|c|} 
Additional cases that would \\
never present passively
\end{tabular}

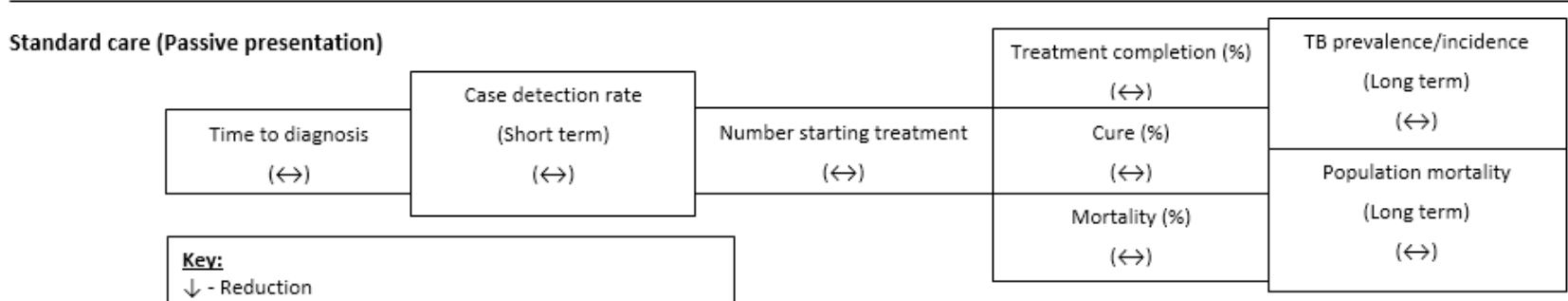

$\uparrow$ - Increase

$\leftrightarrow$ - Point estimates in the control group (baseline)

? - Point estimates in the intervention group

People who present late to health services, when the disease is severe, tend to have poorer health outcomes (Greenaway 2002). Decreasing the time to diagnosis could therefore translate into improved health outcomes for people with tuberculosis. These may be disease-related outcomes, such as cure or death, but could also be socioeconomic outcomes, such as reduced time off work or reduced loss of earnings. Although diagnosing patients early could reduce transmission, there are also concerns that diagnosing people early may lead to higher levels of default from treatment, with subsequent increased spread of resistance.

Although the aim of these interventions is to increase tuberculosis case detection in the short term, the long-term aim is a reduction in community transmission of tuberculosis, and a consequent fall in tuberculosis incidence and case detection (Golub 2005).

\section{Why it is important to do this review}

Early diagnosis is one of the key components of the WHO End TB Strategy published in 2015 (WHO 2015b). It is therefore important to know which interventions work, and under what circumstances.

\section{O B J E C T IVES}

To evaluate the effectiveness of different strategies to increase tuberculosis case detection through improved access (geographical, financial, educational) to tuberculosis diagnosis at primary healthcare or community-level services.

\section{METHODS}

\section{Criteria for considering studies for this review}

Types of studies

Randomized controlled trials (RCTs) for which the unit of randomization is the individual or cluster, and non-randomized studies with parallel control groups.

\section{Types of participants}

People living in areas with moderate to high tuberculosis prevalence (tuberculosis notification rate of greater than 10 tuberculosis cases per 100,000 population per year).

\section{Types of interventions}

\section{Intervention}

Any intervention that aims to improve access to a tuberculosis diagnosis by providing diagnostic services at primary health care or community level. This included educational or health promotion activities, and outreach services using formal and informal health staff through clinics, mobile clinics, and house-to-house screening.

\section{Control}

No intervention (standard care) or an alternative intervention for improving access to a tuberculosis diagnosis. 


\section{Types of outcome measures}

\section{Primary outcomes}

- Tuberculosis cases detected (microbiologically confirmed) refers to tuberculosis patients with a positive result of either acid-fast bacilli (AFB) sputum smear microscopy or GeneXpert MTB/RIF and/or mycobacterial culture (solid or liquid culture).

\section{Secondary outcomes}

- Tuberculosis cases starting treatment are all forms tuberculosis patients (either microbiologically confirmed or not) who are started on tuberculosis treatment as reported by individual study.

- Time to diagnosis refers to time the presumptive tuberculosis patient presents at the health facility until the tuberculosis diagnosis is made.

- False-positive results with the initial tuberculosis screening test refers to a positive test result and the individual is erroneously classified as positive for tuberculosis due to imperfect testing methods or procedures.

- Default within the first two months is classified as early default (prior to commencing tuberculosis treatment or during the intensive phase of treatment).

- Treatment completion refers to a tuberculosis patient who completed treatment without evidence of failure BUT there is no record to show that sputum smear or culture results in the last month of treatment and on at least one previous occasion are negative, either because they were not done or because results were not available.

- Tuberculosis cured refers to pulmonary tuberculosis patient who was initially microbiologically confirmed at the beginning of treatment and who had either a negative sputum smear or culture result at the last month of treatment and on at least one previous occasion.

- Tuberculosis mortality refers to tuberculosis patients who die for any reason before starting or during the course of tuberculosis treatment.

- Population tuberculosis mortality refers to any cause of death at the population level during the active case-finding implementation.

- Programme cost refers to the cost per diagnosed case of tuberculosis.

- Long-term tuberculosis prevalence refers to the reduction in tuberculosis prevalence (either microbiologically confirmed or not) in a study population.

\section{Search methods for identification of studies}

We identified all relevant studies regardless of language or publication status (published, unpublished, in press, and ongoing)

\section{Electronic searches}

We searched the following databases: the Cochrane Infectious Disease Group Specialized Register; the Cochrane Central Register of Controlled Trials (CENTRAL, published in the Cochrane Library, Issue 12, 2016); MEDLINE (PubMed, 1966 to 19 December 2016); Embase (OVID, 1980 to 19 December 2016); Science Citation Index Expanded (SCI-EXPANDED) and Social Sciences Citation Index (SSCI; Web of Science, 1900 to 19 December 2016); BIOSIS Previews (Web of Science, 1926 to 19 December 2016); and Scopus
(1970 to 19 December 2016), using the search terms detailed in Appendix 1. We also searched the metaRegister of Controlled Trials (mRCT), the World Health Organization International Clinical Trials Registry Platform (WHO ICTRP) (www.who.int/trialsearch), and ClinicalTrials.gov (clinicaltrials.gov/) (all accessed on 19 December 2016), using 'tuberculosis' and 'case detection' or 'case finding' or 'active screening' as search terms.

\section{Searching other resources}

We checked the reference lists of all studies identified by the above methods for other potentially relevant studies.

\section{Data collection and analysis}

\section{Selection of studies}

Two review authors (FM and AM) each independently screened all the citations and abstracts to identify potential eligible studies using a study selection form. We obtained the full reports of potentially eligible studies. FM and AM assessed these for inclusion in the review using a predesigned eligibility form based on the inclusion criteria. Any discrepancies were resolved through discussion or, if required, by consulting a third review author (RD, DS, or LC). Where necessary we contacted the study authors for clarification of study methods. We listed the reasons for excluding studies in the 'Characteristics of excluded studies' table.

\section{Data extraction and management}

Two review authors (FM and AM) independently extracted data from the studies using a tailored data extraction form. Any differences in data extraction were resolved through discussion or, if necessary, by consulting a third review author (DS). We extracted the following study information.

- Study details: start and end dates, study location, study design, funding, tuberculosis prevalence (as stated by the study authors).

- Participant details: who was recruited for tuberculosis diagnostic testing? Where were they recruited? What were the eligibility criteria for a person to have a tuberculosis test?

- Details of the intervention: what was the initial screening test? What was the diagnostic test? Who conducted the screening? What training did they have? How long were they trained for? What were they trained to do? How were they supervised? Who trained them?

- Details of any co-interventions: were there any additional health promotion activities? Was tuberculosis testing free? Were there any financial/material incentives/enablers?

- Details of the control: what diagnostic services were available to the control groups? What were the local barriers to care? Distance to health services? Cost of attending health facilities?

For dichotomous outcomes (for example, additional tuberculosis cases starting treatment), we extracted the number experiencing the event (numerator) and the total number of people diagnosed with tuberculosis (denominator). For continuous outcomes, we extracted the mean, the standard deviation, and the number of people observed.

\section{Cluster-RCTs}

For cluster-RCTs, we recorded the number of clusters, the average size of the clusters, and the method used to adjust for clustering. 
If the trial authors adjusted for clustering appropriately, we extracted the cluster-adjusted measure of effect and a measure of variance. For dichotomous outcomes, we extracted the number of participants experiencing the event and the number randomized to each group if the authors did not adjust for clustering. For continuous outcomes, we extracted the summary effect (mean or median) and the measure of variance (standard deviation or range). We extracted the adjusted effect estimate and the standard error for studies that had adjusted for clustering.

\section{Non-RCTs}

For non-RCTs, we extracted details of any method used to control confounding, the chosen confounder variables, any reported treatment effects adjusted for one or more baseline characteristics, or any other treatment effect estimate that took confounding into account, for example the overall treatment effects estimate obtained by combining treatment effects from different strata of a study, or an estimate that allows for matching. We contacted the authors for unclear or missing data.

After data extraction, FM entered the data into Review Manager 5 (RevMan 5) (RevMan 2014).

\section{Assessment of risk of bias in included studies}

Two review authors (FM and AM) independently assessed the risk of bias of each included study using the Cochrane 'Risk of bias' tool (RevMan 2014), and discussed any differences of opinion. In the case of missing or unclear information, we contacted the trial authors for clarification. Review authors who had been involved in any of the included trials were excluded from the 'Risk of bias' assessment,

The Cochrane approach assesses risk of bias across six domains: sequence generation and allocation concealment (selection bias), blinding of participants and personnel (performance bias), blinding of outcome assessors (detection bias), incomplete outcome data (attrition bias), selective outcome reporting (reporting bias), and other potential biases. For each domain, we recorded the methods used by the study authors to reduce the risk of bias and assigned a judgement of 'low risk of bias', 'high risk of bias', or 'unclear'.

For cluster-RCTs, we also considered recruitment bias, baseline imbalance in the appraisal of selection bias, loss of clusters in the appraisal of attrition bias, incorrect analysis, comparability with RCTs, and further considered the risk of contamination bias (where people living in the control areas also benefit from the intervention).

Similarly, for non-RCTs we used the Risk of Bias In Non-randomized Studies - of Interventions (ROBINS-I) to assess the risk of bias for non-randomized trials (Sterne 2016). We considered the seven bias domains grouped into pre-intervention (bias due to confounding and selection of participants into study), at intervention (bias in classification of interventions), and post-intervention (bias due to deviations from intended interventions, missing data, measurement of outcomes, and selection of the reported results).

We summarized the results for the assessment of risk of bias using the 'Risk of bias' summary and the 'Risk of bias' graph in addition to the 'Risk of bias' tables.

\section{Measures of treatment effect}

For dichotomous data, we used risk ratios as the primary measure of effect. Where study authors have presented data as odds ratios we recalculated the effect. Count data are expressed as rate ratios. For continuous data, we compared arithmetic means using mean differences. We presented all measures with $95 \%$ confidence intervals (Cls). Medians and ranges are reported in table format only.

\section{Unit of analysis issues}

Where cluster-RCTs have not adjusted their results for the effect of the cluster design, we adjusted the sample sizes using the methods described in Section 16.3.4 or 16.3.6 of the Cochrane Handbook for Systematic Reviews of Interventions (Higgins 2011), employing an estimate of the intracluster correlation coefficient (ICC). Where possible, we derived the ICC from the trial itself, or from a similar trial. If an appropriate ICC was not available, we conducted sensitivity analyses to investigate the potential effect of clustering by imputing a range of values of ICC.

When a multi-arm study contributed multiple comparisons to a particular meta-analysis, we either combined treatment groups or split the 'shared' group as appropriate to avoid double counting.

\section{Dealing with missing data}

We applied no imputation for missing data. We attempted to contact trial authors to obtain missing or unclear data.

\section{Assessment of heterogeneity}

We assessed for statistical heterogeneity between trials by visually inspecting the forest plots to detect overlapping $\mathrm{Cls}$, and applying the $\mathrm{Chi}^{2}$ test and $\mathrm{I}^{2}$ statistic. We considered a Chi ${ }^{2}$ test $\mathrm{P}$ value less than 0.10 as statistically significant. An $I^{2}$ statistic value of $0 \%$ to $30 \%$ might not be important; $30 \%$ to $60 \%$ may represent moderate heterogeneity; and more than $60 \%$ may indicate substantial or considerable heterogeneity.

\section{Assessment of reporting biases}

We planned to assess the likelihood of reporting bias using funnel plots, but there were too few studies.

\section{Data synthesis}

We analysed the data using RevMan 5 (RevMan 2014). The primary analysis was stratified by study design, and we did not perform meta-analysis across different trial designs.

We also stratified outcomes by the time point of outcome measurement. Where appropriate, we grouped similar time points together and performed a meta-analysis (for example, tuberculosis case detection at six to 12 months). When interpreting data at different time points, we kept in mind that the desired outcome of the intervention may change with time. For example, a successful intervention may increase tuberculosis case detection in the short term, but if it influences transmission it may result in a fall in tuberculosis case detection in the long term.

We tabulated results from cluster-RCTs that could be adjusted for clustering. We used a random-effects model in the presence of moderate statistical heterogeneity and a fixed-effect model in the absence of heterogeneity. 


\section{Subgroup analysis and investigation of heterogeneity}

We investigated potential causes of heterogeneity by performing subgroup analyses by tuberculosis prevalence.

\section{Sensitivity analysis}

We planned to perform sensitivity analyses to evaluate the robustness of the results to the risk of bias components, but there were too few studies to make this meaningful.

\section{RES U LTS}

\section{Description of studies}

\section{Results of the search}

The study flow diagram is shown in Figure 2. The initial searches identified 1646 studies, of which 81 were deemed potentially relevant to this review after the initial abstract screening.

\section{Figure 2. Study flow diagram.}

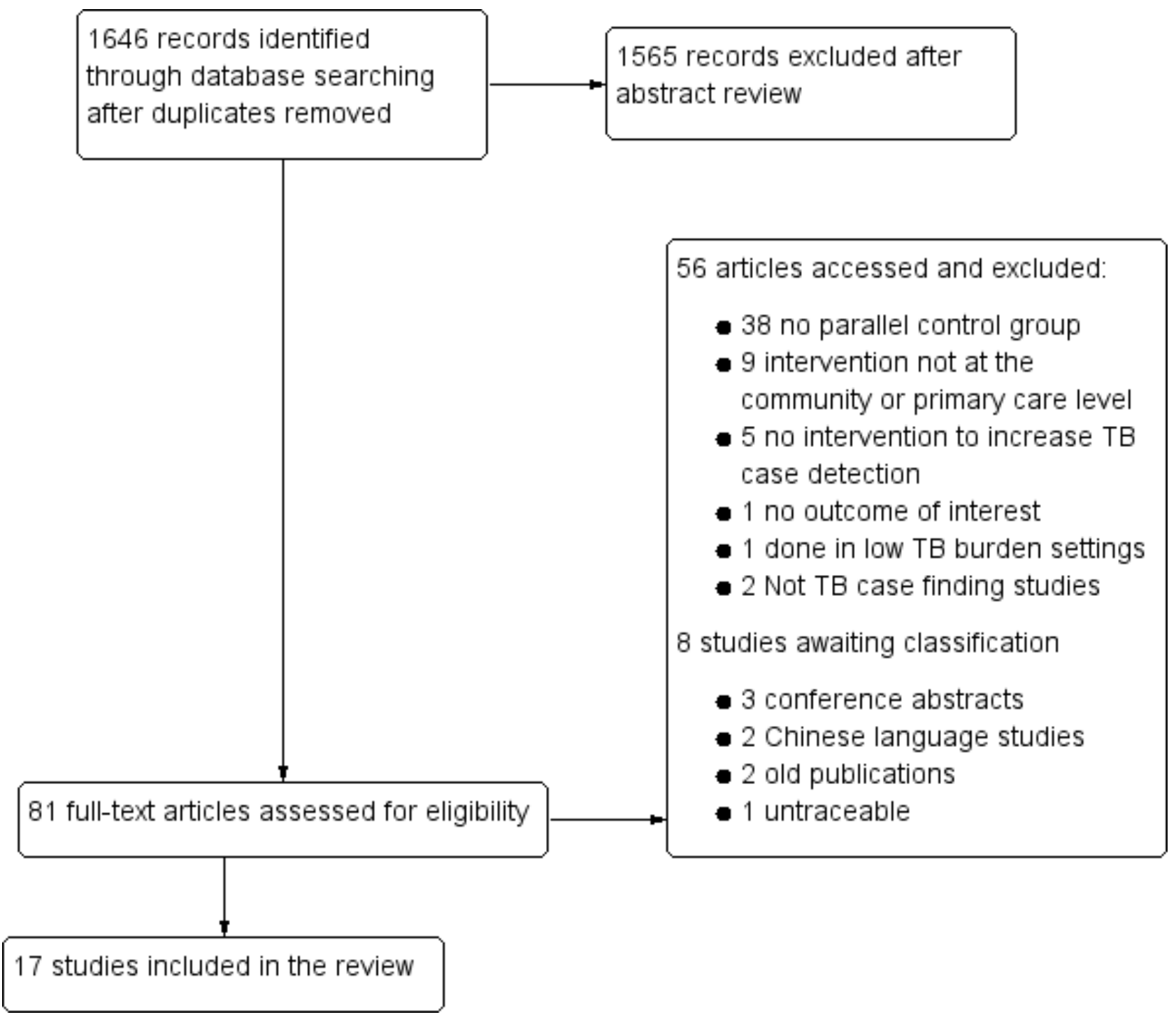

\section{Included studies}

We included 17 studies: nine cluster-randomized trials (Ayles 2013 ZMB AND ZAF; Clarke 2005 ZAF; Corbett 2010 ZWE; Datiko 2009 ETH; Fairall 2005 ZAF; Miller 2010 BRA; Shargie 2006 ETH; Talukder 2012 BGD), one individual randomized trial (Moyo 2012 ZAF), and seven non-RCTs (Jaramillo 2001 COL; Joshi 2015 NPL; Khan 2012 PAK; Khan 2016 PAK; Oshi 2016 NGA; Reddy 2015 IND; Yassin 2013 ETH).

Nine studies were conducted in sub-Saharan Africa (Ethiopia, Nigeria, South Africa, Zambia, and Zimbabwe), six in Asia
(Bangladesh, Cambodia, India, Nepal, and Pakistan), and two in South America (Brazil and Colombia).

Most of the studies evaluated interventions with multiple components. In 10 studies health workers actively looked for tuberculosis cases outside of conventional health facilities (contact tracing: Ayles 2013 ZMB AND ZAF; Joshi 2015 NPL; Oshi 2016 NGA; outreach clinics: Corbett 2010 ZWE; Joshi 2015 NPL; Shargie 2006 ETH; house-to-house screening: Clarke 2005 ZAF; Corbett 2010 ZWE; Datiko 2009 ETH; Joshi 2015 NPL; Miller 2010 BRA; Morishita 2016 KHM; Reddy 2015 IND; Yassin 2013 ETH), 13 studies included 
some form of health promotion activities to encourage people to attend health facilities for tuberculosis screening and testing (Ayles 2013 ZMB AND ZAF; Corbett 2010 ZWE; Datiko 2009 ETH; Jaramillo 2001 COL; Joshi 2015 NPL; Khan 2012 PAK; Miller 2010 BRA; Oshi 2016 NGA; Reddy 2015 IND; Shargie 2006 ETH; Talukder 2012 BGD; Yassin 2013 ETH), and most studies included training activities to improve the diagnostic skills available at health facilities (see Table $1)$.

Sixteen studies evaluated case-finding interventions compared to standard passive case finding at health facilities, while three studies provided direct head-to-head comparisons of different case-finding interventions (Ayles 2013 ZMB AND ZAF; Corbett 2010 ZWE; Miller 2010 BRA).

Most studies presented the raw data for the number of tuberculosis cases detected (microbiologically confirmed) in a defined population, but only three presented an estimate of effect appropriately adjusted for the cluster design. Only one study attempted to evaluate the effects of interventions on long-term tuberculosis prevalence (Ayles 2013 ZMB AND ZAF), and this study measured prevalence at 3.5 to 4.5 years after the intervention had begun.

Thirteen studies used a symptom questionnaire as an entry point for microbiological testing. Sputum microscopy was used to diagnose tuberculosis in 17 studies. In addition, three studies conducted mycobacterial culture and chest X-ray (Ayles 2013 ZMB AND ZAF; Corbett 2010 ZWE; Fairall 2005 ZAF); one study added chest $\mathrm{X}$-ray to symptoms screening to screen presumptive tuberculosis patients (Morishita $2016 \mathrm{KHM}$ ); two studies used a tuberculin skin test (Joshi 2015 NPL; Moyo 2012 ZAF); and two studies used GeneXpert MTB/RIF (Khan 2012 PAK; Morishita 2016 KHM).

\section{Excluded studies}

We excluded 56 studies because they did not meet the inclusion criteria. The reasons for their exclusion are presented in the Characteristics of excluded studies section.

Eight references remain unclassified as we have been unable to access full-text copies: three conference abstracts (Gadala 2015; Jensen 2015; Poliakova 2015), two Chinese language studies (Chen 1990; Duanmu 2005), two old publications (Grzybowski 1965; Ursov 1970), and one reference that we have been unable to trace (Nadu 2004).

\section{Risk of bias in included studies}

For a summary of the 'Risk of bias' assessments see Figure 3. 
Figure 3. 'Risk of bias' summary: review authors' judgements about each 'Risk of bias' item for each included trial.

\begin{tabular}{|c|c|c|c|c|c|c|c|}
\hline & 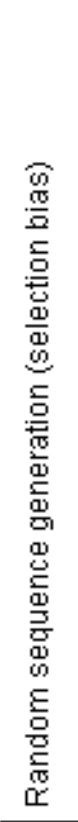 & 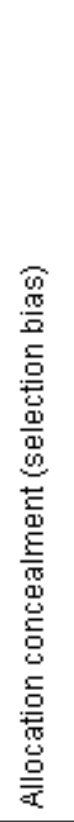 & 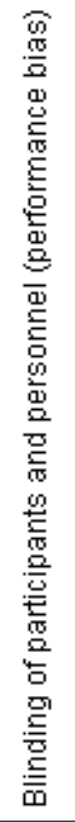 & 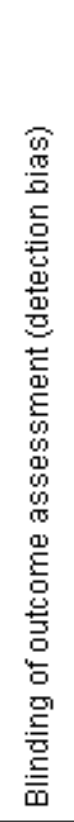 & 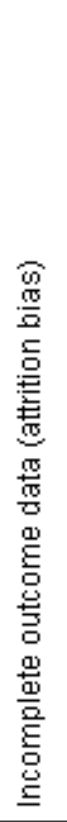 & 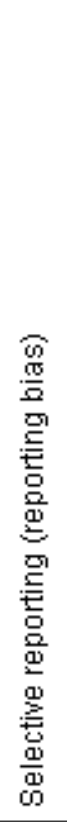 & 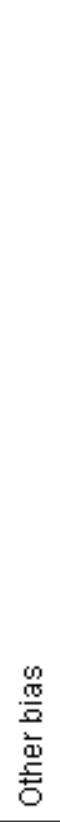 \\
\hline Ayles 2013 ZMB AND ZAF & 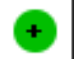 & + & $\oplus$ & $\oplus$ & $\odot$ & $\odot$ & + \\
\hline Clarke 2005 ZAF & + & $\odot$ & $\odot$ & $?$ & $\odot$ & $\odot$ & 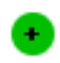 \\
\hline Corbett $2010 \mathrm{ZWE}$ & $\odot$ & $\odot$ & + & + & $?$ & $\odot$ & + \\
\hline Datiko 2009 ETH & + & + & + & $?$ & + & $\odot$ & $\odot$ \\
\hline Fairall $2005 \mathrm{ZAF}$ & + & + & + & + & + & $\odot$ & + \\
\hline Jaramillo $2001 \mathrm{COL}$ & & - & + & $?$ & $?$ & $\odot$ & + \\
\hline Joshi $2015 \mathrm{NPL}$ & & - & $\odot$ & $?$ & $?$ & $\odot$ & ) \\
\hline Khan 2012 PAK & - & - & + & + & $?$ & $\odot$ & + \\
\hline Khan 2016 PAK & - & - & + & + & $?$ & + & + \\
\hline Miller $2010 \mathrm{BRA}$ & + & $?$ & $?$ & $?$ & $?$ & $\odot$ & + \\
\hline Morishita $2016 \mathrm{KHM}$ & $\odot$ & $\odot$ & $\odot$ & + & $?$ & $?$ & $\odot$ \\
\hline Moyo 2012 ZAF & + & + & + & + & + & + & + \\
\hline Oshi 2016 NGA & - & - & + & $?$ & $?$ & $?$ & + \\
\hline Reddy 2015 IND & - & - & $\oplus$ & $?$ & $?$ & $\odot$ & + \\
\hline Shargie 2006 ETH & $?$ & $?$ & + & $?$ & + & + & + \\
\hline Talukder 2012 BGD & $?$ & $?$ & $\oplus$ & $?$ & $\oplus$ & $\odot$ & + \\
\hline Yassin 2013 ETH & & $\odot$ & + & $\odot$ & $?$ & $\odot$ & + \\
\hline
\end{tabular}




\section{Allocation}

Five out of nine cluster-randomized studies adequately described a suitable method for generating the random sequence and were judged to be at low risk of selection bias (Ayles 2013 ZMB AND ZAF; Clarke 2005 ZAF; Corbett 2010 ZWE; Datiko 2009 ETH; Fairall 2005 ZAF); in the other four the description was unclear. Although allocation concealment was not described for most of the cluster-randomized studies, cluster-randomized studies are normally considered to be at low risk of selection bias as the allocation of all clusters is usually done in a single step.

We judged the non-randomized trials to be at high risk of selection bias.

\section{Blinding}

None of the trials described blinding of health workers or populations (and this would have been impossible to do), but this is unlikely to bias the measured effects of the intervention.

Five of the randomized studies blinded microscopists or outcome assessors to the treatment allocation and were judged to be at low risk of detection bias (Ayles 2013 ZMB AND ZAF; Corbett 2010 ZWE; Fairall 2005 ZAF; Moyo 2012 ZAF).

\section{Incomplete outcome data}

Seven studies were at low risk of attrition bias (Ayles 2013 ZMB AND ZAF; Clarke 2005 ZAF; Datiko 2009 ETH; Fairall 2005 ZAF; Morishita 2016 KHM; Shargie 2006 ETH; Talukder 2012 BGD), and the other 10 studies were at unclear risk of attrition bias (Corbett 2010 ZWE; Jaramillo 2001 COL; Joshi 2015 NPL; Khan 2012 PAK; Miller 2010 BRA; Moyo 2012 ZAF; Oshi 2016 NGA; Reddy 2015 IND; Yassin 2013 ETH)

\section{Selective reporting}

We identified one study with unclear risk of selective reporting bias (Oshi 2016 NGA).

\section{Other potential sources of bias}

We identified no other sources of bias.

\section{Effects of interventions}

See: Summary of findings for the main comparison Tuberculosis outreach screening versus no intervention; Summary of findings 2 Health promotion activities versus no intervention; Summary of findings 3 Training interventions compared to no intervention; Summary of findings $\mathbf{4}$ Outreach tuberculosis screening versus health promotion; Summary of findings 5 Outreach clinic versus house-to-house screening

\section{Comparison 1: Outreach tuberculosis screening with or without health promotion activities versus no intervention}

See Summary of findings for the main comparison.

Four cluster-RCTs and four controlled before-and-after studies evaluated the effects of tuberculosis diagnostic outreach services into the community. All but one of these interventions also included extensive health promotion activities. For details see Table 1 and Table 2.
Of the cluster-RCTs, Ayles 2013 ZMB AND ZAF screened all household contacts of people with active tuberculosis; Shargie 2006 ETH conducted monthly diagnostic outreach clinics in each cluster; Datiko 2009 ETH used health extension workers who visited every household every two weeks to screen for tuberculosis; and Morishita 2016 KHM used healthcare workers and community volunteers who screened households for a period of one year. Clarke 2005 ZAF was a much smaller trial in which lay health workers screened all farm workers for tuberculosis every month.

Of the non-randomized studies, Yassin 2013 ETH and Reddy 2015 IND screened for active tuberculosis in people's homes; Joshi 2015 NPL used volunteers to conduct contact tracing, set up mobile clinics, and screen at homes and schools; and Oshi 2016 NGA conducted contact tracing plus screening at outpatient clinics and antiretroviral therapy clinics.

\section{Tuberculosis cases detected (microbiologically confirmed)}

Among the cluster-RCTs, only Shargie 2006 ETH and Datiko 2009 ETH presented estimates of the effect of the intervention on tuberculosis case detection (microbiologically confirmed) that were appropriately adjusted for the cluster design (see Table 3). However, as both studies used different measures of effect, we have presented an alternative analysis approximately adjusted for the cluster design using the most conservative ICC (from Datiko 2009 ETH).

Analysis 1.1 presents the findings of four studies (Clarke 2005 ZAF; Datiko 2009 ETH; Morishita 2016 KHM; Shargie 2006 ETH), the number of tuberculosis cases detected (microbiologically confirmed) may increase in the intervention groups (risk ratio (RR) $1.24,95 \% \mathrm{Cl} 0.86$ to $1.79 ; 4$ trials, 163,043 participants in 297 clusters, low-certainty evidence). We further analysed by tuberculosis prevalence and presented in Analysis 1.2. Analysis 1.2 presents the findings of four studies (Clarke 2005 ZAF; Datiko 2009 ETH; Morishita 2016 KHM; Shargie 2006 ETH), which we subgrouped by tuberculosis prevalence of less than $5 \%$ (Clarke 2005 ZAF) and 5\% or more (Datiko 2009 ETH; Morishita 2016 KHM; Shargie 2006 ETH). The study among farm workers in South Africa found with calculate prevalence of less than $5 \%$ showed no obvious effect of the intervention (RR $0.85,95 \% \mathrm{Cl} 0.60$ to $1.19 ; 1$ trial, 8887 participants, Analysis 1.2). In the studies by Datiko 2009 ETH, Morishita $2016 \mathrm{KHM}$, and Shargie 2006 ETH, the number of tuberculosis cases detected was higher in the intervention areas (RR $1.52,95 \% \mathrm{Cl} 1.10$ to 2.09 ; 3 trials, 155,918 participants in 51 clusters, Analysis 1.2, low-certainty evidence).

Analysis 1.3 presents the tuberculosis cases detected microbiologically confirmed by intervention. Overall, the point estimates were similar the overall combined interventions as presented in Analysis 1.1. Tuberculosis outreach clinics plus health promotion (Shargie 2006 ETH) may increase tuberculosis cases detected (RR 1.28, 95\% Cl 0.76 to 2.17, Analysis 1.3.1). Similarly, the house-to-house screening plus health promotion for three clusterRCTs (Clarke 2005 ZAF; Datiko 2009 ETH; Morishita 2016 KHM) may increase tuberculosis cases detected (RR $1.25,95 \% \mathrm{Cl} 0.75$ to 2.08 , Analysis 1.3.2).

The cluster-RCT by Morishita 2016 KHM reported "TB cases detected (all forms)", and the results were consistent with the effects seen in studies that reported microbiologically confirmed 
tuberculosis cases detected with RR $1.28(95 \% \mathrm{Cl} 0.83$ to 1.98 , Analysis 1.4).

Of the non-randomized studies, Yassin 2013 ETH and Joshi 2015 NPL reported increases in tuberculosis case notification per 100,000 in the intervention areas compared to control areas (see Table 3); Oshi 2016 NGA and Reddy 2015 IND only reported the number of tuberculosis cases detected without clear denominators, but both reported increased numbers in the intervention areas compared to the pre-intervention period $(+31 \%$ and $+8 \%$, respectively).

\section{Tuberculosis treatment outcomes}

None of the studies included in this review adjusted for clustering for the treatment outcomes that they reported. We therefore used a conservative ICC of 0.001 for all the treatment outcomes.

Treatment default was substantially lower in those diagnosed through outreach services compared to standard health facilities (mean treatment default across studies: $10 \%$ versus $16 \%$; RR 0.67 , $95 \% \mathrm{Cl} 0.47$ to 0.96 ; Analysis 1.5 , low-certainty evidence). In all three randomized trials reporting tuberculosis treatment outcomes, treatment success was slightly higher in the intervention groups compared to the control group (mean treatment success across studies: $84 \%$ versus $78 \%$ ). Although the direction of the effect was towards the intervention, there was very little difference indicated by the point estimate (RR $1.07,95 \% \mathrm{Cl} 1.00$ to 1.15 ; Analysis 1.6, lowcertainty evidence). The number of treatment failures and deaths was low in all three randomized trials, so the analysis of differences was underpowered (treatment failures: RR $1.57,95 \% \mathrm{Cl} 0.50$ to 4.92; Analysis 1.7; tuberculosis mortality: RR $0.99,95 \% \mathrm{Cl} 0.43$ to 2.25 , Analysis 1.8, 849 patients, very low-certainty evidence). Only one of the non-randomized studies reported treatment outcomes (Yassin 2013 ETH).

People diagnosed in intervention areas had higher treatment success $(85 \%$ versus $77 \%)$, and lower default (3\% versus $11 \%)$ during the implementation period compared to the preintervention period (Yassin 2013 ETH).

\section{Long-term tuberculosis prevalence}

Only Ayles 2013 ZMB AND ZAF evaluated the effects on long-term prevalence of tuberculosis. In a cross-sectional prevalence study, 3.5 to 4.5 years after the intervention started, there was no effect demonstrated (881 per 100,000 intervention areas versus 773 per 100,000 control areas; RR $1.14,95 \% \mathrm{Cl} 0.65$ to $2.00 ; 1$ study, 556,836 participants in 12 clusters, Analysis 1.9, very low-certainty evidence). The authors also presented an additional analysis adjusted for multiple confounders such as tuberculosis and HIV prevalence, household socioeconomic status, age, sex, and smoking history, with no obvious effect detected (RR $0.89,95 \% \mathrm{Cl} 0.62$ to 1.29 ).

\section{Comparison 2: Health promotion activities versus no intervention}

See Summary of findings 2 .

Two cluster-RCTs, Ayles 2013 ZMB AND ZAF and Talukder 2012 BGD, and two non-randomized studies, Khan 2012 PAK and Jaramillo $2001 \mathrm{COL}$, evaluated health promotion activities that encourage attendance at health services for tuberculosis screening.
These health promotion activities ranged from extensive mass media strategies (television/radio/newspapers) to more local, community-based activities (leafleting, community meetings, school-based drama). For details see Table 1.

\section{Tuberculosis cases detected (microbiologically confirmed)}

Neither of the two cluster-RCTs presented an estimate of the effect of the intervention on tuberculosis case detection (see Table 4). Ayles 2013 ZMB AND ZAF used long-term tuberculosis prevalence as the primary outcome, and Talukder 2012 BGD only reported the number of people referred for testing in intervention areas without a population-level denominator. However, Talukder 2012 $B G D$ reported that the number of cases detected was higher in the intervention areas ( $P=0.001$; author's own figures).

Of the two non-randomized studies, Khan 2012 PAK reported that tuberculosis case detection doubled during the intervention period (343 per 100,000 during intervention versus 176 per 100,000 preintervention), but remained stable in the parallel control area (46 per 100,000 during intervention versus 41 per 100,000 preintervention). Jaramillo $2001 \mathrm{COL}$ only presented quarterly data on the number of smears conducted, the number of people tested, and the number of tuberculosis cases notified. These data suggest a temporal association between the intervention period and an increase in the number of smears and people tested. However, there was not a convincing corresponding increase in the number of tuberculosis case notifications.

\section{Long-term tuberculosis prevalence}

Ayles 2013 ZMB AND ZAF conducted a cross-sectional prevalence study 3.5 to 4.5 years after the intervention started. There was no effect demonstrated on tuberculosis prevalence at this time point (1012 per 100,000 intervention areas versus 773 per 100,000 control areas; RR $1.31,95 \% \mathrm{Cl} 0.75$ to $2.29 ; 1$ trial, 405,788 participants in 12 clusters, Analysis 2.1, very low-certainty evidence). The authors presented an additional analysis adjusted for multiple confounders such as tuberculosis and HIV prevalence, household socioeconomic status, age, sex, and smoking history, but did not demonstrate a difference (RR $1.04,95 \% \mathrm{Cl} 0.72$ to 1.51 ).

\section{Tuberculosis treatment outcomes}

None of the studies reported comparisons of tuberculosis treatment outcomes between intervention and control areas, or between pre- and post-intervention periods.

\section{Comparison 3: Staff training compared to none}

See Summary of findings 3

One cluster-RCT evaluated health worker education compared to no intervention (Fairall 2005 ZAF). In South Africa, nurse practitioners working in primary care clinics were given between two and six educational sessions. One quasi-experimental study evaluated nurses who were trained on case management and monitoring tools in participating health facilities (Khan 2016 PAK). A summary of the tuberculosis case-finding outcomes for the two studies is shown in Table 5.

\section{Tuberculosis cases detected (microbiologically confirmed)}

In South Africa, Fairall 2005 ZAF reported an increase in the number of tuberculosis cases diagnosed per 1000 patient consults (RR 1.68, $95 \% \mathrm{Cl} 1.03$ to 2.72; 1 trial, 1999 participants, Analysis 3.1, low- 
certainty evidence). One non-randomized study, Khan 2016 PAK, reported that tuberculosis case detection more than tripled in the intervention group (511 tuberculosis cases per 100,000 in the intervention group versus 135 tuberculosis cases per 100,000 in the control group).

Other outcomes, including tuberculosis treatment outcomes and long-term tuberculosis prevalence, were not reported.

\section{Comparison 4: Outreach tuberculosis screening versus health promotion}

See Summary of findings 4

Two cluster-RCTs directly compared outreach tuberculosis screening with health promotion activities. Ayles 2013 ZMB AND ZAF compared tuberculosis contact tracing with extensive health promotion activities encouraging health service attendance, and Miller 2010 BRA compared house-to-house screening with the distribution of informational leaflets to all households (see Table 6).

\section{Tuberculosis cases detected (microbiologically confirmed)}

Only Miller 2010 BRA reported the effect on tuberculosis case detection. During the study period, tuberculosis case detection was higher with house-to-house screening than with health promotion (9.34 per 1000 person years versus 6.04 per 1000 person years; rate ratio $1.55,95 \% \mathrm{Cl} 1.10$ to $1.99,1$ trial, 23,553 participants in 14 clusters, Analysis 4.1). However, a second analysis including the intervention period plus 60 days postintervention attenuated this apparent effect (RR 1.05, 95\% Cl 0.56 to 1.54). See Table 7 .

\section{Long-term prevalence}

The cluster-RCT from Zambia and South Africa was a crosssectional prevalence study 3.5 to 4.5 years after the intervention started (Ayles 2013 ZMB AND ZAF). The study had four arms: control arm, health promotion activities, contact tracing, and contact tracing plus health promotion. None of the interventions were shown to reduce prevalence compared to control.

\section{Tuberculosis treatment outcomes}

Miller 2010 BRA reported that time to diagnosis and treatment completion were not significantly different between the two groups.

\section{Comparison 5: Outreach clinic versus house-to-house screening}

\section{See Summary of findings 5}

One cluster-RCT directly compared the effects of a six-monthly outreach tuberculosis clinic (a mobile van) versus six-monthly house-to-house screening (see Table 6) (Corbett 2010 ZWE).

\section{Tuberculosis cases detected (microbiologically confirmed)}

The number of tuberculosis cases detected was higher with the outreach clinic in each of the six rounds of the interventions, and the cumulative case detection over the three years of the trial was $48 \%$ higher (RR $1.48,95 \% \mathrm{Cl} 1.11$ to $1.97 ; 1$ trial, 405,819 participants, Analysis 5.1, very low-certainty evidence). The authors note that this was unexpected, as the mobile clinic is a less intensive method of case finding, and required self presentation at a public clinic specializing in the diagnosis of a disease associated with poverty and HIV. The authors acknowledge this and suggest that the mobile clinic may have been more convenient, and allowed people to encourage those with symptoms to attend. The home visits were conducted between 9 am and $4 \mathrm{pm}$, when many people may have been absent, but repeated visits (up to three) including at least one weekend visit attempted to mitigate this.

\section{Long-term tuberculosis prevalence}

Corbett 2010 ZWE reported that overall tuberculosis prevalence declined by around $44 \%$ over the three years of the intervention (95\% Cl $17 \%$ to $62 \%$; author's own figures), with no difference detected between the two interventions; however, this is an uncontrolled observation that could be part of a wider temporal trend unassociated with the intervention.

\section{Tuberculosis treatment outcomes}

Not described.

\section{Comparison 6: Active case-finding interventions versus no intervention}

In this comparison we evaluated any interventions that had any component of active case finding versus no intervention. We included five studies (Clarke 2005 ZAF; Datiko 2009 ETH; Fairall 2005 ZAF; Morishita 2016 KHM; Shargie 2006 ETH). The results did not differ from comparison one to four (Analysis 6.1; Analysis 6.2; Analysis 6.3; Analysis 6.4; Analysis 6.5; Analysis 6.6; Analysis 6.7; Analysis 6.8; Analysis 6.9).

\section{Comparison 7: Outreach tuberculosis services versus no intervention (sensitivity analyses)}

In this comparison we included studies that did not present ICC for the tuberculosis treatment outcome (tuberculosis treatment default, tuberculosis treatment success, tuberculosis treatment failure, and tuberculosis mortality). This comparison demonstrates the results for conservative ICC of 0.001 and the ICC as given by Datiko 2009 ETH. The results did not differ when adjusting for each of the ICCs considered (Analysis 7.5; Analysis 7.6; Analysis 7.7; Analysis 7.8).

\section{DISCUSSION}

\section{Summary of main results}

Tuberculosis outreach screening (with and without health promotion) to encourage presumptive tuberculosis patients to attend healthcare services may increase tuberculosis case detection in settings where the prevalence of undiagnosed tuberculosis disease is high. This was shown in four cluster-RCTs (low-certainty evidence).

Regular tuberculosis diagnostic outreach clinics may also increase tuberculosis case detection (low-certainty evidence).

There is insufficient evidence to determine if sustained improvements in case detection impact on long-term tuberculosis prevalence, as the only controlled study to evaluate this found no effect after four years of contact tracing plus intensive health promotion intervention (very low-certainty evidence).

In all of these trials, there were modest effects on treatment success and default from treatment in participants diagnosed through outreach/screening services (moderate-certainty evidence). 


\section{Overall completeness and applicability of evidence}

We included 17 studies in this review, which have implemented various interventions with contradictory results. Some of the interventions may have a large effect on increasing tuberculosis case detection (microbiologically confirmed), whereas other interventions showed no evidence of being effective. This is perhaps not unexpected, as the efficacy of any tuberculosis casefinding intervention is likely to be dependent on multiple factors such as the prevalence of undiagnosed tuberculosis, local barriers to accessing care, and the practical details of implementation, which may include tuberculosis diagnostic tool used. While we will discuss some of the potential reasons for the presence or absence of demonstrable effects, the limited number of studies for each intervention, and the very limited number of settings in which these interventions have been implemented, limit our ability to make broad generalizations.

The study by Corbett 2010 ZWE from Zimbabwe is particularly interesting as it brings up as many questions as it answers. For those considering periodic tuberculosis diagnostic outreach clinics as the most feasible and affordable option in their setting, this study provides some reassurance that these clinics can be effective. Indeed, the lack of demonstrable effect of monthly clinics in Shargie 2006 ETH may simply be due to the statistical imprecision of the trial (that is, the intervention was effective but a bigger trial was needed to demonstrate this), or may reflect suboptimal implementation of the clinics (that is, they were conducted in the wrong place at the wrong time or were inadequately publicized).

However, the finding that six-monthly outreach clinics were actually more effective than house-to-house visits needs to be interpreted with caution, as it is counterintuitive. The explanation offered by the study authors was that the monthly clinics were somehow more acceptable or accessible to the population. This explanation is reasonable, but again demonstrates how reliant the effects of any intervention are on the practical details of implementation, such as the timing of visits. The intervention effect might disappear or even reverse with different cultural norms, different attitudes towards tuberculosis, or different timing or settings for the clinics or home visits.

Corbett 2010 ZWE also presented evidence of a declining prevalence in tuberculosis over the three years of the study, which was notably absent in the trial by Ayles 2013 ZMB AND ZAF. The interventions in the two trials are obviously different, and one interpretation for the results might be that contact tracing and health promotion alone are not sufficient to reduce tuberculosis prevalence, whereas outreach clinics and household screening are. However, the evidence from Corbett 2010 ZWE is observational in nature, and highly susceptible to confounding. It is also surprising that the same decline was seen in both study arms despite a clear difference in tuberculosis case detection between the two arms. The decline may therefore be due to other temporal trends or activities, rather than the case-finding intervention itself.

The overall limitations of the studies included in this review are as follows.

- Small sample sizes that were not powered to detect a clinical difference in tuberculosis treatment outcomes such as mortality and default rate.
- The likelihood of false-positive results from sputum smear acidfast bacilli (AFB) microscopy, especially in low tuberculosis prevalence settings, with implications for the overestimation of notification rates and favourable treatment outcomes (treatment success).

- Considerable heterogeneity of interventions that reduced the certainty of the evidence of each reviewed outcome.

- Considerable heterogeneity of the health systems in which the interventions were implemented.

\section{Quality of the evidence}

We assessed the certainty of the evidence in this review using the GRADE approach and presented the evidence in five 'Summary of findings' tables.

We generally downgraded the certainty of evidence for the primary outcome of tuberculosis case detected (microbiologically confirmed) to 'low' despite most trials being well conducted. One of the main reasons for this downgrading was indirectness, as the findings of single trials are not easily generalized to other settings. As discussed above, effects will vary widely in line with local tuberculosis prevalence and local implementation.

We considered the certainty of evidence for the secondary outcome of long-term tuberculosis prevalence to be 'very low'. Again, this does not represent inadequacies in the conduct of the trial, but rather reflects the ongoing uncertainty about whether tuberculosis case-finding interventions could reduce prevalence. We downgraded the single study for indirectness (as the findings are not easily generalized to other settings) and imprecision (as the level of statistical certainty does not exclude the possibility of important effects).

\section{Potential biases in the review process}

We minimized potential biases during the review process by adhering to the guidelines of the Cochrane Handbook for Systematic Reviews of Interventions (Higgins 2011) and the Methodological Expectations of Cochrane Intervention Reviews (MECIR) (Higgins 2016). We conducted a comprehensive search of all languages for both peer-reviewed and grey literature. Two review authors independently assessed study eligibility, extracted data, and assessed the risk of bias in each included trial.

The findings of this review are based on the extensive and updated search of the studies done in high-burden tuberculosis countries. The extensive risk of bias assessment was applied for both randomized and non-randomized trials which helped to critically interpret the findings. The strength of the review is that it enables an assessment of various interventions applied either at the community or the primary healthcare setting to increase tuberculosis case detection. The limitations of the study include the following.

- The diversity of interventions and low number of studies to make a good comparison and asses the level of evidence.

- There is also diversity of diagnostic tools with varying sensitivity such as smear microscopy and more sensitive molecular test like Gene Xpert MTB/RIF.

- The effect of the interventions on tuberculosis treatment outcome was limited because of the low number of tuberculosis patients. 


\section{Agreements and disagreements with other studies or reviews}

A previous systematic review by Kranzer and colleagues concentrated on the yield of tuberculosis cases achieved with various active case-finding strategies (Kranzer 2012). As such, they included both controlled studies (included here) and uncontrolled studies (which we excluded). The use of 'yield' as an outcome, especially without a control group, has limitations, as it can be unclear whether these cases would have presented passively anyway. However, Kranzer and colleagues also note that people with tuberculosis identified through screening tended to be less sick, and have had the illness for less time, which is consistent with successfully identifying more cases.

Kranzer 2012 also had a wider scope, and included interventions within high-risk communities such as prisons and clinics for people with HIV. They found that generally the yield was lowest with population screening, which may make population screening less attractive and affordable in many settings.

\section{AUTHORS' CONCLUSIONS}

\section{Implications for practice}

The available evidence demonstrates that when interventions are used in high-burden settings, active case-finding approaches may increase tuberculosis case detection in the short term in moderateto high-tuberculosis prevalence settings. However, it is unclear from the available evidence if active case-finding interventions may improve treatment success and reduce tuberculosis treatment failure, mortality, and default.

\section{Implications for research}

For the purposes of this review, we chose to only include controlled trials, as these most reliably demonstrate the true effects of any intervention, and will be most useful to decision-makers designing local interventions. However, it is likely that many national or local decisions will be based upon uncontrolled pilot studies demonstrating an acceptable yield of tuberculosis cases (microbiologically confirmed) with an intervention that is deemed affordable, and that the implementation of the intervention will be periodically modified through monitoring and audit. This pragmatic approach is a perfectly reasonable form of evidencebased decision-making, and we hope that this summary of the global evidence base assists in those decisions. Further studies are being conducted to utilize GeneXpert Ultra (a more sensitive version of the Xpert MTB/RIF cartridge) as the first test for screening populations using active case finding. It is therefore likely that the pool of studies will increase in the near future.

In the future there is a need to design and conduct trials employing appropriate case detection methods for children, in whom tuberculosis is an important cause of illness. The trials could include scoring systems for children using chest X-rays, signs and symptoms, and results of tuberculin skin tests.

\section{ACKN OWLEDGEMENTS}

FM was supported by a fellowship offered by Cochrane South Africa, South African Medical Research Council, funded by the Effective Health Care Research Consortium. David Sinclair was supported as an author and editor with the Cochrane Infectious Diseases Group by the Effective Health Care Research Consortium. This Consortium and the editorial base of the Cochrane Infectious Diseases Group are funded by UK aid from the UK Government for the benefit of low-income countries (Grant: 5242). The views expressed in this review do not necessarily reflect UK government policy. 


\section{R E F E R E N C E S}

\section{References to studies included in this review}

Ayles 2013 ZMB AND ZAF \{published data only\}

* Ayles H, Muyoyeta M, Du Toit E, Schaap A, Floyd S, Simwinga $\mathrm{M}$, et al. Effect of household and community interventions on the burden of tuberculosis in southern Africa: the ZAMSTAR community-randomised trial. Lancet 2013;382(9899):1183-94.

Sismanidis C, Moulton LH, Ayles H, Fielding K, Schaap A, Beyers N, et al. Restricted randomization of ZAMSTAR a $2 \times 2$ factorial cluster randomized trial. Clinical Trials 2008;5(4):316-27.

\section{Clarke 2005 ZAF \{published data only\}}

Clarke M, Dick J, Zwarenstein M, Lombard CJ, Diwan VK. Lay health worker intervention with choice of DOT superior to standard TB care for farm dwellers in South Africa: a cluster randomised control trial. International Journal of Tuberculosis and Lung Disease 2005;9(6):673-9.

\section{Corbett 2010 ZWE \{published data only\}}

Corbett EL, Bandason T, Duong T, Dauya E, Makamure B, Churchyard GJ, et al. Comparison of two active case-finding strategies for community-based diagnosis of symptomatic smear-positive tuberculosis and control of infectious tuberculosis in Harare, Zimbabwe (DETECTB): a clusterrandomised trial. Lancet 2010;376(9748):1244-53.

\section{Datiko 2009 ETH \{published data only\}}

Datiko DG, Lindtjørn B. Health extension workers improve tuberculosis case detection and treatment success in southern Ethiopia: a community randomized trial. PLOS ONE 2009;4(5):e5443.

\section{Fairall 2005 ZAF \{published data only\}}

Fairall L, Bachmann MO, Zwarenstein M, Bateman ED, Niessen LW, Lombard C, et al. Cost-effectiveness of educational outreach to primary care nurses to increase tuberculosis case detection and improve respiratory care: economic evaluation alongside a randomised trial. Tropical Medicine \& International Health 2010;15(3):277-86.

\section{Jaramillo 2001 COL \{published data only\}}

Jaramillo E. The impact of media-based health education on tuberculosis diagnosis in Cali, Colombia. Health Policy Plan 2001;16(1):68-73.

\section{Joshi 2015 NPL \{published data only\}}

Joshi B, Chinnakali P, Shrestha A, Das M, Kumar AM, Pant R, et al. Impact of intensified case-finding strategies on childhood TB case registration in Nepal. Public Health Action 2015;5(2):93-8.

\section{Khan 2012 PAK \{published data only\}}

Khan AJ, Khowaja S, Khan FS, Qazi F, Lotia I, Habib A, et al. Engaging the private sector to increase tuberculosis case detection: an impact evaluation study. Lancet Infectious Diseases 2012;12(8):608-16.
Khan 2016 PAK \{published data only\}

Khan MA, Munir MA, Anil S, Ahmad M, Walley J, Qadeer E, et al. Structured performance monitoring of TB-care at facility, district and province levels - Pakistan experience. Journal of the Pakistan Medical Association 2016;66(4):418-24.

Miller 2010 BRA \{published data only\}

Miller AC, Golub JE, Cavalcante SC, Durovni B, Moulton LH, Fonseca $Z$, et al. Controlled trial of active tuberculosis case finding in a Brazilian favela. International Journal of Tuberculosis and Lung Disease 2010;14(6):720-6.

\section{Morishita 2016 KHM \{published data only\}}

Morishita F, Eang MT, Nishikiori N, Yadav RP. Increased case notification through active case finding of tuberculosis among household and neighbourhood contacts in Cambodia. PLOS ONE 2016;11(3):e0150405.

\section{Moyo 2012 ZAF \{published data only\}}

Moyo S, Verver S, Hawkridge A, Geiter L, Hatherill M, Workman $L$, et al. Tuberculosis case finding for vaccine trials in young children in high-incidence settings: a randomised trial. International Journal of Tuberculosis and Lung Disease 2012;16(2):185-91.

\section{Oshi 2016 NGA \{published data only\}}

Oshi DC, Chukwu JN, Nwafor CC, Meka AO, Madichie NO, Ogbudebe $\mathrm{CL}$, et al. Does intensified case finding increase tuberculosis case notification among children in resourcepoor settings? A report from Nigeria. International Journal of Mycobacteriology 2016;5(1):44-50.

\section{Reddy 2015 IND \{published data only\}}

Reddy KK, Ananthakrishnan R, Jacob AG, Das M, Isaakidis P, Kumar AM. Intensified tuberculosis case finding amongst vulnerable communities in southern India. Public Health Action 2015;5(4):246-8.

\section{Shargie 2006 ETH $\{$ published data only\}}

Shargie EB, Mørkve O, Lindtjørn B. Tuberculosis case-finding through a village outreach programme in a rural setting in southern Ethiopia: community randomized trial. Bulletin of World Health Organization 2006;84(2):112-9.

Talukder 2012 BGD \{published data only\}

Talukder K, Salim MA, Jerin I, Sharmin F, Talukder MQ Marais B J, et al. Intervention to increase detection of childhood tuberculosis in Bangladesh. International Journal of Tuberculosis and Lung Disease 2012;16(1):70-5.

\section{Yassin 2013 ETH $\{$ published data only\}}

Yassin MA, Datiko DG, Tulloch O, Markos P, Aschalew M, Shargie EB, et al. Innovative community-based approaches doubled tuberculosis case notification and improve treatment outcome in Southern Ethiopia. PLoS ONE 2013;8(5):e63174. 


\section{References to studies excluded from this review}

\section{Abdurrahman 2017 \{published data only\}}

Abdurrahman ST, Lawson L, Blakiston M, Obasanya J, Yassin MA, Anderson RM, et al. Are patients with pulmonary tuberculosis who are identified through active case finding in the community different than those identified in healthcare facilities?. New Microbes New Infections 2017;15:35-9.

\section{Ade 2016 \{published data only\}}

Ade S, Békou W, Adjobimey M, Adjibode O, Ade G, Harries AD, et al. Tuberculosis case finding in Benin, 2000-2014 and beyond: a retrospective cohort and time series study. Tuberculosis Research and Treatment 2016;2016:3205843.

\section{Adejumo 2016 \{published data only\}}

Adejumo AO, Azuogu B, Okorie O, Lawal OM, Onazi OJ, Gidado $M$, et al. Community referral for presumptive TB in Nigeria: a comparison of four models of active case finding. $B M C$ Public Health 2016;16:177.

\section{Anger 2012 \{published data only\}}

Anger HA, Proops D, Harris TG, Li J, Kreiswirth BN, Shashkina E, et al. Active case finding and prevention of tuberculosis among a cohort of contacts exposed to infectious tuberculosis cases in New York City. Clinical Infectious Diseases 2012;54(9):1287-95.

\section{Arora 2004 \{published data only\}}

Arora VK, Lonnroth K, Sarin R. Improved case detection of tuberculosis through a public-private partnership. Indian Journal of Chest Diseases and Allied Sciences 2004;46(2):133-6.

\section{Atif 2013 \{published data only\}}

Atif M, Sulaiman SAS, Shafie AA, Asif M, Jamshed SQ. Engaging community pharmacists and alternative practitioners: an approach to active case finding of tuberculosis in Malaysia. Tropical Journal of Pharmaceutical Research 2013;12(6):1093-5.

\section{Bai 2008 \{published data only\}}

Bai LQ, Yang HL, Jian XW, He XG, Chen YF, Tang Y, et al. Increasing tuberculosis case detection through intensive referral and tracing in Hunan, China. International Journal of Tuberculosis and Lung Disease 2008;12(12):1431-5.

\section{Balcha 2015 \{published data only\}}

Balcha TT, Skogmar S, Sturegard E, Bjorkman P, Winqvist N. Outcome of tuberculosis treatment in HIV-positive adults diagnosed through active versus passive case-finding. Global Health Action 2015;8:27048.

\section{Bassili 2011 \{published data only\}}

Bassili A, Seita A, Baghdadi S, Enarson D. Tuberculosis case finding in twenty-two countries of the Eastern Mediterranean Region. International Journal of Tuberculosis and Lung Disease 2011;15(4):556-61.

\section{Bernard 2012 \{published data only\}}

Bernard C, Sougakoff W, Fournier A, Larnaudie S, Antoun F, Robert J, et al. Impact of a 14-year screening programme on tuberculosis transmission among the homeless in Paris.
International Journal of Tuberculosis and Lung Disease 2012;16(5):649-55.

Bothamley 2008 \{published data only\}

Bothamley GH, Ditiu L, Migliori GB, Lange C. Active case finding of tuberculosis in Europe: a Tuberculosis Network European Trials Group (TBNET) survey. European Respiratory Journal 2008;32(4):1023-30.

Charles 2016 \{published data only\}

Charles M K, Lindegren M L, Wester C W, Blevins M, Sterling T $\mathrm{R}$, Dung N T, et al. Implementation of tuberculosis intensive case finding, isoniazid preventive therapy, and infection control ("three I's") and HIV-tuberculosis service integration in lower income countries. PLOS ONE 2016;11(4):e0153243.

Churchyard 2011 \{published data only\}

Churchyard GJ, Fielding K, Roux S, Corbett EL, Chaisson RE, De Cock KM, et al. Twelve-monthly versus six-monthly radiological screening for active case-finding of tuberculosis: a randomised controlled trial. Thorax 2011;66(2):134-9.

Del Portillo-Mustieles 2013 \{published data only\}

Del Portillo-Mustieles EC, Laniado-Laborin R. Active case finding of pulmonary tuberculosis through screening of respiratory symptomatics using sputum microscopy: Is it time to change the paradigm?. Tuberc Res Treat 2013;2013:312824.

\section{Delva 2016 \{published data only\}}

Delva G J, Francois I, Claassen C W, Dorestan D, Bastien B, Medina-Moreno $S$, et al. Active tuberculosis case finding in Port-au-Prince, Haiti: experiences, results, and implications for tuberculosis control programs. Tuberculosis Research and Treatment 2016;2016:8020745.

\section{den Boon 2008 \{published data only\}}

den Boon S, Verver S, Lombard CJ, Bateman ED, Irusen EM, Enarson DA, et al. Comparison of symptoms and treatment outcomes between actively and passively detected tuberculosis cases: the additional value of active case finding. Epidemiol Infect 2008;136(10):1342-9.

\section{Dholakia 2016 \{published data only\}}

Dholakia Y, Mistry N. Active tuberculosis case finding in a migrant slum community, Mumbai, India. International Journal of Tuberculosis and Lung Disease 2016;20(11):1562.

Dobler 2016 \{published data only\} Dobler C C. Screening strategies for active tuberculosis: focus on cost-effectiveness. ClinicoEconomics \& Outcomes Research 2016;8:335-47.

\section{Eang 2012 \{published data only\}}

Eang MT, Satha P, Yadav RP, Morishita F, Nishikiori N, vanMaaren $P$, et al. Early detection of tuberculosis through community-based active case finding in Cambodia. BMC Public Health 2012;12:469.

Elden 2011 \{published data only\}

Elden S, Lawes T, Kudsk-Iversen S, Vandelanotte J, Nkawanyana S, Welfare W, et al. Integrating intensified case 
finding of tuberculosis into HIV care: an evaluation from rural Swaziland. BMC Health Serv Res 2011;11:118. [DOI: 10.1186/1472-6963-11-118]

\section{Fatima 2016 \{published data only\}}

Fatima R, Qadeer E, Yaqoob A, Haq M U, Majumdar S S, Shewade H D, et al. Extending 'contact tracing' into the community within a 50-metre radius of an index tuberculosis patient using Xpert MTB/RIF in urban, Pakistan: did It increase case detection?. PLOS ONE 2016;11(11):e0165813.

\section{Fox 2012 \{published data only\}}

Fox GJ, Sy DNS, Nhung NV, Lien LT, Cuong NK, Britton WJ, et al. Active case-finding of tuberculosis among household contacts in Hanoi, Vietnam - a 12-month prospective study. Respirology. Canberra: Australian and New Zealand Society of Respiratory Science Canberra, 2012; Vol. Conference.

\section{Furin 2007 \{published data only\}}

Furin JJ, Rigodon J, Cancedda C, Keshavjee S, Seung KJ, Letsie $\mathrm{M}$, et al. Improved case detection of active tuberculosis associated with an antiretroviral treatment program in Lesotho. Int J Tuberc Lung Dis 2007;11(10):1154-6.

\section{Gebi 2009 \{published data only\}}

Gebi UL, Musa B, Alfred N, Abimiku A, Dakum P, Blattner W, et al. Opportunity for scaleup; mobile X-ray technology - strengthening TB diagnosis in HIV+ve patients; ACTION experience in Zaria, rural Northern Nigeria. Journal of Acquired Immune Deficiency Syndromes. Baltimore, 2009; Vol. Conference.

\section{Gilpin 1987 \{published data only\}}

Gilpin TP, Hammond M. Active case-finding - for the whole community or for tuberculosis contacts only?. South African Medical Journal 1987;72(4):260-2.

\section{Gonzalez-Ochoa 2009 \{published data only\}}

Gonzalez-Ochoa E, Brooks JL, Matthys F, Caliste P, Armas L, Van der Stuyft P. Pulmonary tuberculosis case detection through fortuitous cough screening during home visits. Trop Med Int Health 2009;14(2):131-5.

\section{Gorbacheva 2010 \{published data only\}}

Gorbacheva O, Mishra AK, Shapovalov D, Sudtasay S. Prevalence of bacteriologically confirmed pulmonary tuberculosis in the Bhutanese refugees in Nepal results of active case finding. International Journal of Infectious Diseases. Miami: International Congress on Infectious Diseases (ICID), 2010; Vol. 14:E150.

\section{Gounder 2011 \{published data only\}}

Gounder CR, Wada NI, Kensler C, Violari A, McIntyre J, Chaisson RE, et al. Active tuberculosis case-finding among pregnant women presenting to antenatal clinics in Soweto, South Africa. J Acquir Immune Defic Syndr 2011;57(4):e77-84.

\section{Griffiths 2007 \{published data only\}}

Griffiths C, Sturdy P, Brewin P, Bothamley G, Eldridge S, Martineau $A$, et al. Educational outreach to promote screening for tuberculosis in primary care: a cluster randomised controlled trial. Lancet 2007;369(9572):1528-34.

\section{Hermans 2012 \{published data only\}}

Hermans S, Nasuuna E, van Leth F, Byhoff E, Schwarz M, Hoepelman A, et al. Implementation and effect of intensified case finding on diagnosis of tuberculosis in a large urban HIV clinic in Uganda: a retrospective cohort study. BMC Public Health 2012;12:674.

\section{Hinderaker 2011a \{published data only\}}

Hinderaker SG, Rusen ID, Chiang CY, Yan L, Heldal E, Enarson DA. The FIDELIS initiative: innovative strategies for increased case finding. Int J Tuberc Lung Dis 2011;15(1):71-6.

\section{Hossain 2010 \{published data only\}}

Hossain S, Larson CP, Quaiyum MA, Khan Al, Zaman K, Begum V, et al. Adults with chronic cough in urban Bangladesh: healthcare utilization and management of cases by private practitioners. World Health Popul 2010;12(1):5-17.

\section{Kaboru 2013 \{published data only\}}

Kaboru BB. Active referral: an innovative approach to engaging traditional healthcare providers in TB control in Burkina Faso. Healthcare Policy 2013;9(2):51-64.

\section{Kakinda 2016 \{published data only\}}

Kakinda M, Matovu JK, Obuku EA. A comparision of the yield of three tuberculosis screening modalities among people living with HIV: a retrospective quasi-experiemental study. BMC Public Health 2016;16(1):1080.

\section{Khan 2007 \{published data only\}}

Khan MS, Dar O, Sismanidis C, Shah K, Godfrey-Faussett P. Improvement of tuberculosis case detection and reduction of discrepancies between men and women by simple sputumsubmission instructions: a pragmatic randomised controlled trial. Lancet 2007;369(9577):1955-60.

\section{Kuznetsov 2014 \{published data only\}}

Kuznetsov VN, Grjibovski AM, Mariandyshev AO, Johansson E, Bjune GA. A comparison between passive and active case finding in TB control in the Arkhangelsk region. Int J Circumpolar Health 2014;73:23515. [DOI: 10.3402/ ijch.v73.23515]

\section{Lebina 2016 \{published data only\}}

Lebina L, Fuller N, Osoba T, Scott L, Motlhaoleng K, Rakgokong M, et al. The Use of Xpert MTB/RIF for Active Case Finding among TB Contacts in North West Province, South Africa. Tuberculosis Research and Treatment 2016;2016:4282313.

\section{Ntinginya 2012 \{published data only\}}

Ntinginya NE, Squire SB, Millington KA, Mtafya B, Saathoff E, Heinrich N, et al. Performance of the Xpert ${ }^{\circledR}$ MTB/RIF assay in an active case-finding strategy: a pilot study from Tanzania. International Journal of Tuberculosis and Lung Disease 2012;16(11):1468-70. 
Oshi 2016 \{published data only\}

Oshi DC, Chukwu JN, Nwafor CC, Meka AO, Madichie NO, Ogbudebe $\mathrm{CL}$, et al. Does intensified case finding increase tuberculosis case notification among children in resourcepoor settings? A report from Nigeria. Int J Mycobacteriol 2016;5(1):44-50.

\section{Prasad 2016 \{published data only\}}

Prasad B M, Satyanarayana S, Chadha S S, Das A, Thapa B, Mohanty $S$, et al. Experience of active tuberculosis case finding in nearly 5 million households in India. Public Health Action 2016;6(1):15-8.

\section{Pronyk 2001 \{published data only\}}

Pronyk PM, Joshi B, Hargreaves JR, Madonsela T, Collinson MA, Mokoena $\mathrm{O}$, et al. Active case finding: understanding the burden of tuberculosis in rural South Africa. International Journal of Tuberculosis and Lung Disease 2001;5(7):611-8.

\section{Ruutel 2011 \{published data only\}}

Ruutel K, Loit H M, Sepp T, Kliiman K, McNutt L A, Uuskula A. Enhanced tuberculosis case detection among substitution treatment patients: a randomized controlled trial. BMC Research Notes 2011;4:192.

\section{Sanaie 2016 \{published data only\}}

Sanaie A, Mergenthaler C, Nasrat A, Seddiq M K, Mahmoodi S D, Stevens R H, et al. An Evaluation of Passive and Active Approaches to Improve Tuberculosis Notifications in Afghanistan. PLoS ONE 2016;11(10):e0163813.

\section{Sekandi 2009 \{published data only\}}

Sekandi JN, Neuhauser D, Smyth K, Whalen CC. Active case finding of undetected tuberculosis among chronic coughers in a slum setting in Kampala, Uganda. International Journal of Tuberculosis and Lung Disease 2009;13(4):508-13.

\section{Sekandi 2014 \{published data only\}}

Sekandi JN, List J, Luzze H, Yin XP, Dobbin K, Corso PS, et al. Yield of undetected tuberculosis and human immunodeficiency virus coinfection from active case finding in urban Uganda. International Journal of Tuberculosis and Lung Disease 2014;18(1):13-9.

\section{Shapiro 2012 \{published data only\}}

Shapiro A E, Variava E, Rakgokong M H, Moodley N, Luke B, Salimi S, et al. Community-based targeted case finding for tuberculosis and HIV in household contacts of patients with tuberculosis in South Africa. American Journal of Respiratory and Critical Care Medicine 2012;185:1110-6.

\section{Shrivastava 2012 \{published data only\}}

Shrivastava SR, Shrivastava PS. Tuberculosis: active case finding survey in an urban area of India, in 2012. Journal of Research in Health Sciences 2012;13(1):19-23.

\section{Soares 2013 \{published data only\}}

Soares ECC, Vollmer WM, Cavalcante SC, Pacheco AG, Saraceni V, Silva JS, et al. Tuberculosis control in a socially vulnerable area: a community intervention beyond DOT in a
Brazilian favela. International Journal of Tuberculosis and Lung Disease 2013;17(12):1581-6, i.

Ssemmondo 2016 \{published data only\}

Ssemmondo E, Mwangwa F, Kironde J L, Kwarisiima D, Clark T $D$, Marquez C, et al. Implementation and Operational Research: Population-Based Active Tuberculosis Case Finding During Large-Scale Mobile HIV Testing Campaigns in Rural Uganda. J Acquir Immune Defic Syndr 2016;73(3):e46-50.

Story 2012 \{published data only\}

Story A, Aldridge RW, Abubakar I, Stagg HR, Lipman M, Watson JM, et al. Active case finding for pulmonary tuberculosis using mobile digital chest radiography: an observational study. Int J Tuberc Lung Dis 2012;16(11):1461-7.

\section{Szkwarko 2016 \{published data only\}}

Szkwarko D, Mercer T, Kimani S, Braitstein P, Buziba N, Carter E J. Implementing intensified tuberculosis case-finding among street-connected youth and young adults in Kenya. Public Health Action 2016;6(2):142-6.

\section{Uwimana 2012 \{published data only\}}

Uwimana J, Zarowsky C, Hausler H, Jackson D. Training community care workers to provide comprehensive TB/HIV/ PMTCT integrated care in KwaZulu-Natal: lessons learnt. Tropical Medicine and International Health 2012;17:488-96.

\section{Wei 2015 \{published data only\}}

Wei X, Zou G, Chong MKC, Xu L. An intervention of active TB case finding among smokers attending routine primary care facilities in China: an exploratory study. Transactions of The Royal Society of Tropical Medicine and Hygiene 2015;109(9):545-52.

\section{Yimer 2009a \{published data only\}}

Yimer S, Holm-Hansen C, Yimaldu T, Bjune G. Evaluating an active case-finding strategy to identify smear-positive tuberculosis in rural Ethiopia. International Journal of Tuberculosis and Lung Disease 2009;13(11):1399-404.

\section{Yimer 2009b \{published data only\}}

Yimer S, Holm-Hansen C, Yimaldu T, Bjune G. Health care seeking among pulmonary tuberculosis suspects and patients in rural Ethiopia: a community-based study. BMC Public Health 2009;9:454

\section{Zhang 2011 \{published data only\}}

Zhang X, Wei X, Zou G, Walley J, Zhang H, Guo X, et al. Evaluation of active tuberculosis case finding through symptom screening and sputum microscopy of close contacts in Shandong, China. Tropical Medicine and International Health 2011;16(12):1511-7.

\section{References to studies awaiting assessment}

Chen 1990 \{published data only\}

Chen QY, Liu TY. An approach to the mode of case findings of pulmonary tuberculosis in countryside. Zhonghua Jie He He Hu Xi Za Zhi 1990;13(4):207-8, 53-4. 


\section{Duanmu 2005 \{published data only\}}

Duanmu HJ, Zheng SH, Xu B, Fu CW. Improved case finding by using sputum examination in pulmonary tuberculosis suspects with clinical symptoms. Zhonghua Jie He He Hu Xi Za Zhi 2005;28(7):468-71.

\section{Gadala 2015 \{published data only\}}

Gadala S, Valsangkar S, Prasad B, Galli C, Dasgupta B, Thomas T. Enhanced case finding in tuberculosis: implementation in marginalized and vulnerable populations in a lower middle income country. American Journal of Respiratory and Critical Care Medicine 2015;191:A3716.

\section{Grzybowski 1965 \{published data only\}}

Grzybowski S, Ashley MJ. Report of a crash tuberculosis program in a high incidence area. Canadian Journal of Public Health 1965;56(12):527-9.

\section{Jensen 2015 \{published data only\}}

Jensen SG, Olsen NW, Seersholm N, Wilcke T, Pedersen MK, Lillebaek T, et al. Infectiousness of tuberculosis patients identified through spot sputum screening compared to patients identified through passive case finding - comparing sputum smear microscopy results. European Respiratory Journal 2015;46:OA1448.

\section{Nadu 2004 \{published data only\}}

Nadu T. Impact of women's self help groups on tuberculosis case-finding in Coimbatore District. International Journal of Tuberculosis and Lung Disease 2004;8(12):210.

\section{Poliakova 2015 \{published data only\}}

Poliakova N, Yedilbayev A, Barnashov A, Zemlyanaya N. Active case finding of tuberculosis, Tomsk (Russia). European Respiratory Journal 2015;46:PA1523.

\section{Ursov 1970 \{published data only\}}

Ursov IG, Murashkin PS, Volokitin FN. Studies of the possibility of house to house visits as a method of tuberculosis case finding in rural districts. Problemy Tuberkuleza 1970;48(8):9-11.

\section{Additional references}

\section{Corbett 2009}

Corbett EL, Bandason T, Cheung YB, Makamure B, Dauya E, Munyati SS, et al. Prevalent infectious tuberculosis in Harare, Zimbabwe: burden, risk factors and implications for control. International Journal of Tuberculosis and Lung Disease 2009;13(10):1231-7.

\section{Glickman 2001}

Glickman MS, Jacobs WR Jr. Microbial pathogenesis of Mycobacterium tuberculosis: dawn of a discipline. Cell 2001;104(4):477-85.

\section{Golub 2005}

Golub JE, Mohan Cl, Comstock GW, Chaisson RE. Active case finding of tuberculosis: historical perspective and future prospects. International Journal of Tuberculosis and Lung Disease 2005;9(11):1183-203.

\section{Greenaway 2002}

Greenaway C, Menzies D, Fanning A, Grewal R, Yuan L, FitzGerald JM, Canadian Collaborative Group in Nosocomial Transmission of Tuberculosis. Delay in diagnosis among hospitalized patients with active tuberculosis - predictors and outcomes. American Journal of Respiratory Critical Care Medicine 2002;165(7):927-33.

\section{Higgins 2011}

Higgins JP, Green S, editor(s). Cochrane Handbook for Systematic Reviews of Interventions Version 5.1.0 (updated March 2011). The Cochrane Collaboration, 2011. Available from handbook.cochrane.org.

\section{Higgins 2016}

Higgins JPT, Lasserson T, Chandler J, Tovey D, Churchill R. Methodological Expectations of Cochrane Intervention Reviews. London: Cochrane, 2016.

\section{Hinderaker 2011}

Hinderaker SG, Madland S, Ullenes M, Enarson DA, Rusen ID, Kamara DV. Treatment delay among tuberculosis patients in Tanzania: data from the FIDELIS Initiative. BMC Public Health 2011;11:306.

\section{Kranzer 2012}

Kranzer K, Afnan-Holmes H, Tomlin K, Golub JE, Shapiro AE, Schaap $A$, et al. The benefits to communities and individuals of screening for active tuberculosis disease: a systematic review. International Journal of Tuberculosis and Lung Disease 2012;17(4):432-46.

\section{Lönnroth 2009}

Lönnroth K, Jaramillo E, Williams BG, Dye C, Raviglione M. Drivers of tuberculosis epidemics: the role of risk factors and social determinants. Social Science and Medicine 2009;68(12):2240-6.

\section{Mfinanga 2008}

Mfinanga SG, Mutayoba BK, Kahwa A, Kimaro G, Mtandu R, Ngadaya $E$, et al. The magnitude and factors associated with delays in management of smear positive tuberculosis in Dar es Salaam, Tanzania. BMC Health Services Research 2008;8:158.

\section{Parsons 2011}

Parsons LM, Somoskövi A, Gutierrez C, Lee E, Paramasivan CN, Abimiku A, et al. Laboratory diagnosis of tuberculosis in resource-poor countries: challenges and opportunities. Clinical Microbiology Reviews 2011;24(2):314-50.

\section{RevMan 2014 [Computer program]}

Nordic Cochrane Centre, The Cochrane Collaboration. Review Manager 5 (RevMan 5). Version 5.3. Copenhagen: Nordic Cochrane Centre, The Cochrane Collaboration, 2014

\section{Sharma 2012}

Sharma SK, Mohanan S, Sharma A. Relevance of latent TB infection in areas of high TB prevalence. Chest 2012;142(3):761-73. 


\section{Steingart 2014}

Steingart KR, Schiller I, Horne DJ, Pai M, Boehme CC, Dendukuri N. Xpert ${ }^{\circledR}$ MTB/RIF assay for pulmonary tuberculosis and rifampicin resistance in adults. Cochrane Database of Systematic Reviews 2014, Issue 1. [DOI: 10.1002/14651858.CD009593.pub3]

\section{Sterne 2016}

Sterne JA, Hernán MA, Reeves BC, Savović J, Berkman ND, Viswanathan M, et al. ROBINS-I: a tool for assessing risk of bias in non-randomised studies of interventions. BMJ 2016;35:i4919.

\section{Storla 2008}

Storla DG, Yimer S, Bjune GA. A systematic review of delay in the diagnosis and treatment of tuberculosis. BMC Public Health 2008;8:15.

\section{WHO 2009}

World Health Organization. Treatment of Tuberculosis: Guidelines. 4th Edition. Geneva: World Health Organization, 2009.

\section{WHO 2011}

World Health Organization. Early Detection of Tuberculosis: An Overview of Approaches, Guidelines and Tools. Geneva: World Health Organization, 2011.

\section{CHARACTERISTICS OF STUDIES}

Characteristics of included studies [ordered by study ID]

\section{WHO 2015a}

Wold Health Organization. Global Tuberculosis Report. Geneva: World Health Organization, 2015.

\section{WHO 2015b}

World Health Organization. The End TB Strategy. Geneva: World Health Organization, 2015.

\section{WHO 2016}

World Health Organization. Global tuberculosis report 2016. www.who.int/tb/publications/global_report/en/ (accessed prior to 26 September 2017).

\section{References to other published versions of this review Mhimbira 2015 \\ Mhimbira FA, Cuevas LE, Dacombe R, Mkopi A, Sinclair D. Interventions to increase tuberculosis case detection at primary healthcare or community level services. Cochrane Database of Systematic Reviews 2015, Issue 1. [DOI: 10.1002/14651858.CD011432]}

* Indicates the major publication for the study

Ayles 2013 ZMB AND ZAF

$\begin{array}{ll}\text { Methods } & \text { Trial design: A } 2 \times 2 \text { factorial design cluster-RCT } \\ & \text { Unit of randomization: Community - average size } 40110 \\ & \text { Number of clusters per study arm: } 6 \\ & \text { Length of follow-up: } 54 \text { months } \\ & \text { Adjusted for cluster design: Yes }\end{array}$

Participants

\author{
Target group: adults 18 years of age or older. \\ Total population of intervention areas: 962,655 \\ Total number of people screened for tuberculosis: 64643 \\ Exclusions: none
}

Tuberculosis screening test: Symptoms in contact tracing, sputum smear in health promotion

Tuberculosis diagnostic test: Sputum smear microscopy and mycobacterial culture

\title{
Intervention area 1: Strengthened tuberculosis-HIV programme plus health promotion
}

- Did they look for TB cases outside of health facilities? No

- Did they use health promotion strategies to encourage people to attend diagnostic services? Yes, through extensive promotion activities people were encouraged to drop sputum samples at central collection points.

- Did they train health workers in TB diagnosis? Yes, the TB-HIV programme was strengthened at all clinics. 
Ayles 2013 ZMB AND ZAF (Continued)

\section{Intervention area 2: Strengthened tuberculosis-HIV programme plus contact tracing}

- Did they look for TB cases outside of health facilities? Yes, household contacts of people diagnosed with TB were screened.

- Did they use health promotion strategies to encourage people to attend diagnostic services? No.

- Did they train health workers in TB diagnosis? Yes, the TB-HIV programme was strengthened at all clinics.

\section{Intervention area 3: A combination of $1+2$}

- Did they look for TB cases outside of health facilities? Yes, household contacts of people diagnosed with TB were screened.

- Did they use health promotion strategies to encourage people to attend diagnostic services? Yes, through extensive promotion activities people were encouraged to drop sputum samples at central collection points.

- Did they train health workers in TB diagnosis? Yes, the TB-HIV programme was strengthened at all clinics.

\section{Control: Strengthened tuberculosis-HIV programme at the clinics only}

\begin{tabular}{|c|c|c|}
\hline Outcomes & \multicolumn{2}{|c|}{$\begin{array}{l}\text { Outcomes included in the review } \\
\text { - Additional tuberculosis cases detected } \\
\text { - Community tuberculosis prevalence at } 3.5 \text { to } 4.5 \text { years postintervention }\end{array}$} \\
\hline Notes & $\begin{array}{l}\text { Countries: Zambia an } \\
\text { Setting: Rural and urb } \\
\text { Tuberculosis prevalen } \\
\text { HIV prevalence: Zamb } \\
\text { Study dates: } 1 \text { August } \\
\text { Study sponsor: Bill \& }\end{array}$ & $\begin{array}{l}\text { South Africa } \\
\text { Zambia and Western Cape in South Africa } \\
\text { e: } 832 \text { per } 100,000 \text { population } \\
\text { : } 15.9 \% \text { to } 18.0 \% \text {, South Africa: } 16.9 \% \text { to } 19.2 \% \\
006 \text { to } 31 \text { July } 2009 \\
\text { linda Gates Foundation }\end{array}$ \\
\hline \multicolumn{3}{|l|}{ Risk of bias } \\
\hline Bias & Authors' judgement & Support for judgement \\
\hline $\begin{array}{l}\text { Random sequence genera- } \\
\text { tion (selection bias) }\end{array}$ & Low risk & $\begin{array}{l}\text { Quote: "Randomization of intervention was stratified by country and the } \\
\text { prevalence of tuberculous infection. Additionally randomization was restricted } \\
\text { to ensure balance of prevalence of tuberculosis infection, HIV prevalence, ur- } \\
\text { ban and rural location, social context and geographical location. A list of } 1000 \\
\text { possible allocations of communities to four groups was drawn as a random } \\
\text { sample from a total of about } 7 \text { million allocations that met restriction criteria." }\end{array}$ \\
\hline
\end{tabular}

\begin{tabular}{ll}
\hline $\begin{array}{l}\text { Allocation concealment } \\
\text { (selection bias) }\end{array}$ & $\begin{array}{l}\text { Quote: "A two stage public randomization ceremony was done, first to select } \\
\text { one of the } 1000 \text { possible allocations of the } 24 \text { communities into four groups, } \\
\text { and second to allocate each of the four trial groups to one of the letters A, B, C, } \\
\text { D" }\end{array}$ \\
\hline
\end{tabular}

\begin{tabular}{|c|c|c|}
\hline $\begin{array}{l}\text { Blinding of participants } \\
\text { and personnel (perfor- } \\
\text { mance bias) }\end{array}$ & Low risk & $\begin{array}{l}\text { Comment: Neither participants nor study personnel were blinded to the inter- } \\
\text { vention group, but this is unlikely to bias the result separately from the effect } \\
\text { of the intervention. }\end{array}$ \\
\hline
\end{tabular}

Blinding of outcome as- Low risk sessment (detection bias)

Quote: "Analysis of sputum samples collected in the prevalence survey was done blinded to group assignment" 
Ayles 2013 ZMB AND ZAF (Continued)

All outcomes

$\begin{array}{ll}\begin{array}{l}\text { Incomplete outcome data } \\ \text { (attrition bias) }\end{array} & \text { Low risk } \\ \text { All outcomes } & \begin{array}{l}\text { Comment: no loss of clusters occurred. A large number of samples were either } \\ \text { missing (2330), failed to meet predefined quality standards (18,101), or were } \\ \text { contaminated (5707). However, the proportions were reasonably balanced } \\ \text { across groups. }\end{array}\end{array}$

\begin{tabular}{lll}
\hline $\begin{array}{l}\text { Selective reporting (re- } \\
\text { porting bias) }\end{array}$ & Low risk & Comment: No evidence of selective reporting \\
\hline Other bias & Low risk & Recruitment bias: Low risk \\
& Baseline imbalance: Similar characteristics (low risk) \\
& Loss of clusters: Low risk \\
& Incorrect analysis: Primary outcome adjusted for clustering. \\
& Comparability with RCTs randomizing individuals: Unclear risk \\
\hline
\end{tabular}

\begin{tabular}{ll} 
Methods & Trial design: cluster-RCT \\
Unit of randomization: farm - median size 44 adult farm workers \\
Number of clusters per study arm: 106 intervention vs 105 control \\
Length of follow-up: 6 months \\
Adjusted for cluster design: yes \\
\hline Participants & Target population: adults aged > 15 years \\
& Total population of intervention areas: 4438 (adults) \\
& Total number of people screened for tuberculosis in intervention areas: not stated \\
& Tuberculosion criteria: multidrug-resistant tuberculosis patients \\
& Tuberculosis diagnostic test: sputum smear microscopy $x 2$
\end{tabular}

\section{Intervention areas}

- Did health workers look for tuberculosis cases outside of health facilities? Yes, lay health workers screened all farm dwellers monthly and referred to tuberculosis centres.

- Were there health promotion activities to encourage people to attend diagnostic services? No.

- Were health workers trained in tuberculosis diagnosis? Yes, lay health workers had 5 weeks of training on tuberculosis, family health, HIV, first aid, and home-based care.

\section{Control areas}

- No intervention

\begin{tabular}{ll}
\hline Outcomes & Outcomes included in the revie \\
- Tuberculosis cases detected \\
- Treatment completion \\
- Tuberculosis cure \\
- Tuberculosis mortality
\end{tabular}

Notes Country: South Africa

Interventions to increase tuberculosis case detection at primary healthcare or community-level services (Review) 
Clarke 2005 ZAF (Continued)

Setting: Rural

Tuberculosis prevalence: Not stated

HIV prevalence: Not stated

Study dates: May 2000 to Sept 2000

Study sponsors: Boland District Municipality, The Medical Research Council of South Africa, UK Department of International Development

\section{Risk of bias}

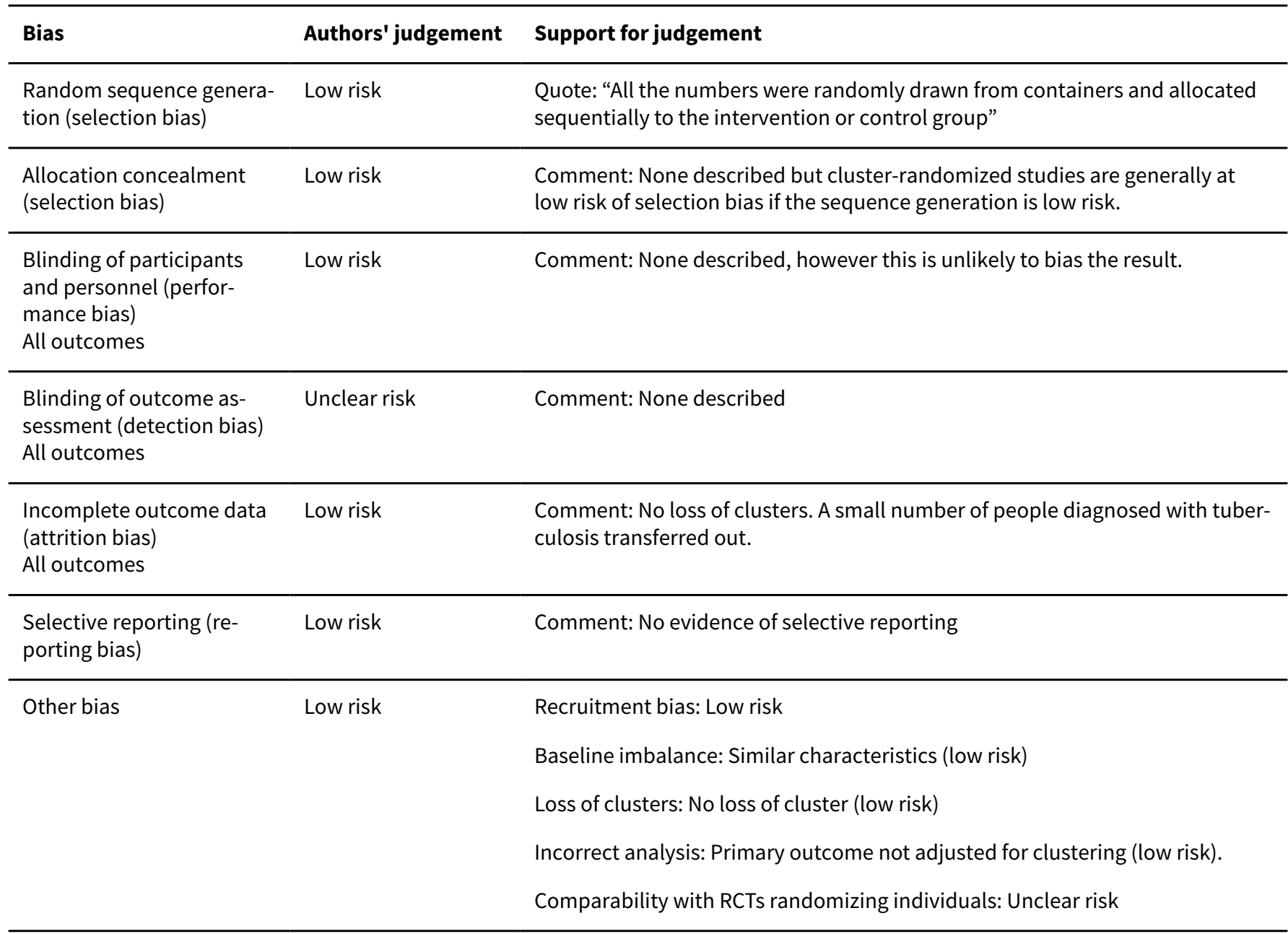

\section{Corbett 2010 ZWE}

$\begin{array}{ll}\text { Methods } & \text { Trial design: Cluster-randomized trial } \\ & \text { Unit of randomization: Areas of residential suburbs - approximate size } 2000 \text { to } 3000 \text { adults } \\ & \text { Number of clusters per study arm: } 23 \\ & \text { Length of follow-up: } 35 \text { months } \\ & \text { Adjusted for cluster design: Yes }\end{array}$

Participants

Target group: Adults aged 16 years or older

Total population of intervention areas: Mobile van: 55,741 vs door-to-door: 54,691 
Corbett 2010 ZWE (Continued)

Total number of people screened for tuberculosis: Mobile van: 5466 vs door-to-door: 4711

Exclusions: None

Tuberculosis screening test: Symptom screen - cough $>2$ weeks

Tuberculosis diagnostic test: Sputum smear, mycobacteria culture, chest X-ray

Interventions Intervention area 1: Mobile van

- Did health workers look for tuberculosis cases outside of health facilities? Yes, a mobile van was located in each cluster for 5 days in each of 6 rounds.

- Were there health promotion activities to encourage people to attend diagnostic services? Yes, a loudspeaker and leafleting encouraged people to attend.

- Were health workers trained in tuberculosis diagnosis? Yes, the tuberculosis-HIV programme was strengthened at all clinics.

\section{Intervention area 2: Door-to-door screening}

- Did health workers look for tuberculosis cases outside of health facilities? Yes, all households were visited up to 3 times in each of 6 rounds by 2 teams of 3 lay field workers.

- Were there health promotion activities to encourage people to attend diagnostic services? No.

- Were health workers trained in tuberculosis diagnosis? Unclear, improvements in the skills of staff at the health clinics were not described.

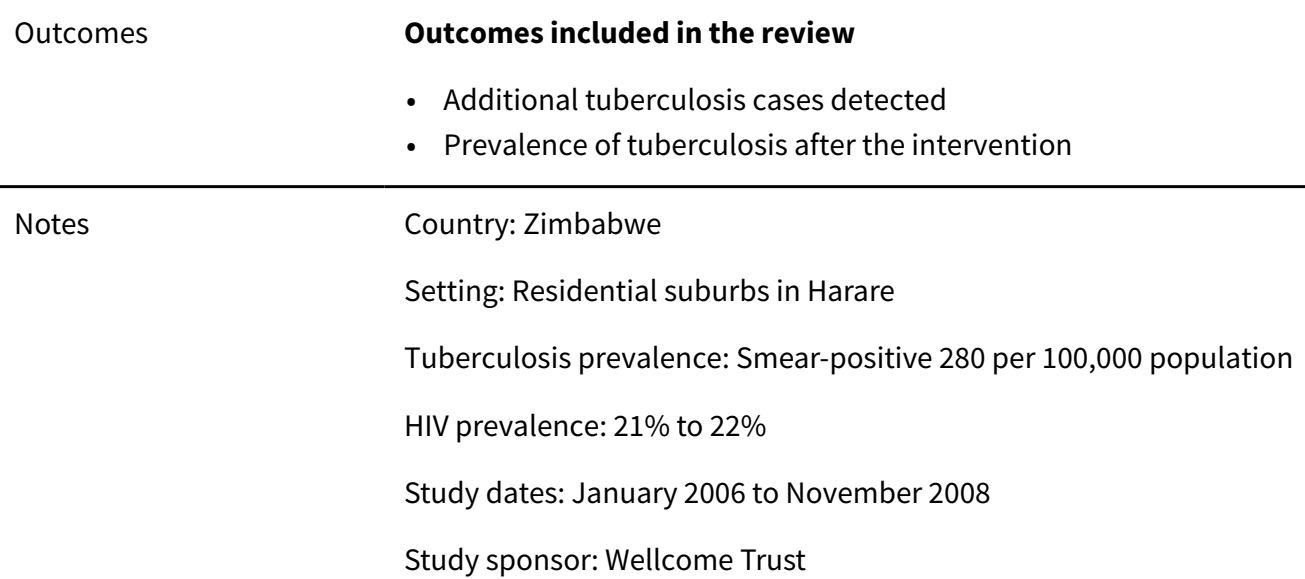

\section{Risk of bias}

Bias Authors' judgement Support for judgement

\begin{tabular}{lll}
\hline $\begin{array}{l}\text { Random sequence genera- } \\
\text { tion (selection bias) }\end{array}$ & Low risk & $\begin{array}{l}\text { Quote: "Randomisation was done by selection of red and black coloured discs } \\
\text { (23 of each colour), which were otherwise identical, from an opaque bag held } \\
\text { above eye-level." }\end{array}$ \\
\hline $\begin{array}{l}\text { Allocation concealment } \\
\text { (selection bias) }\end{array}$ & Low risk & $\begin{array}{l}\text { Quote: "Discs were withdrawn at a public meeting by community advisory } \\
\text { board members representing each cluster. Before selection began, black was } \\
\text { allocated to represent the door-to-door group, and red to represent the mobile } \\
\text { van group" }\end{array}$ \\
\hline $\begin{array}{l}\text { Blinding of participants } \\
\begin{array}{l}\text { and personnel (perfor- } \\
\text { mance bias) }\end{array}\end{array}$ & Low risk & $\begin{array}{l}\text { Quote: "Community health workers and cluster residents were not masked to } \\
\text { the intervention" }\end{array}$ \\
Coutcomes & $\begin{array}{l}\text { Comment: This is unlikely to bias the result separately from the effect of the in- } \\
\text { tervention. }\end{array}$
\end{tabular}


Corbett 2010 ZWE (Continued)

Blinding of outcome as- Low risk Quote: "Laboratory work and clinical management was done without refersessment (detection bias) ence to the intervention group, and interim data were not analysed by interAll outcomes vention group until the final analysis, allowing investigators and laboratory staff to be masked to intervention allocation"

\begin{tabular}{|c|c|c|}
\hline $\begin{array}{l}\text { Incomplete outcome data } \\
\text { (attrition bias) } \\
\text { All outcomes }\end{array}$ & Unclear risk & $\begin{array}{l}\text { Comment: Consent to participate in prevalence surveys was lower in men } \\
(57 \% \text { to } 65 \%) \text { than in women ( } 97 \% \text { to } 98 \%) \text {. The number of missing or contami- } \\
\text { nated sputum samples was not reported. }\end{array}$ \\
\hline
\end{tabular}
nated sputum samples was not reported.

Selective reporting (re- Low risk Comment: No evidence of selective outcomes reporting
porting bias)
porting bias)

\begin{tabular}{ll}
\hline Other bias & Recruitment bias: Low risk \\
& Baseline imbalance: Similar characteristics (low risk) \\
& Loss of clusters: None (low risk) \\
& Incorrect analysis: Primary outcome adjusted for clustering (low risk) \\
& Comparability with RCTs randomizing individuals: Unclear risk \\
\hline
\end{tabular}

\begin{tabular}{l} 
Trial design: Community-randomized trial \\
Unit of randomization: Kebele (lowest administrative unit) - approximate size 5000 people \\
Number of clusters per study arm: 31 intervention versus 21 control \\
Length of follow-up: 19 months \\
Adjusted for cluster design: Yes \\
\hline
\end{tabular}

Participants

\author{
Target group: All ages \\ Total population of intervention areas: 178,138 \\ Total number of people screened for tuberculosis: Not stated \\ Exclusions: None mentioned \\ Tuberculosis screening test: Cough for more than 2 weeks \\ Tuberculosis diagnostic test: Sputum smear microscopy +/- CXR
} sis.

- Did health workers look for tuberculosis cases outside of health facilities? Yes, health extension workers visited all households in the kebeles.

- Were there health promotion activities to encourage people with symptoms to attend health services? Yes, health extension workers conducted health education sessions at health posts.

- Were health workers trained in tuberculosis diagnosis? Yes, health extension workers were trained to screen for chronic cough and collect, store, and transport sputum samples.

\title{
Control areas: No intervention
}


Datiko 2009 ETH (Continued)

- Health extension workers did not receive training, but provided health services including health education about tuberculosis the people living in their kebeles.

\begin{tabular}{ll}
\hline Outcomes & Outcomes included in the review \\
- Additional tuberculosis cases detected \\
- Tuberculosis cure \\
- Early default (prior to commencing treatment or during the intensive phase of treatment) \\
- Tuberculosis mortality \\
Country: Ethiopia \\
Setting: Rural districts of Sidama zone in Southern Ethiopia \\
Tuberculosis prevalence: 122 per 100,000 population \\
HIV prevalence: HIV test was not done and kits were not available during the study \\
Study dates: September 2006 to April 2008 \\
Study sponsor: The University of Bergen
\end{tabular}

\section{Risk of bias}

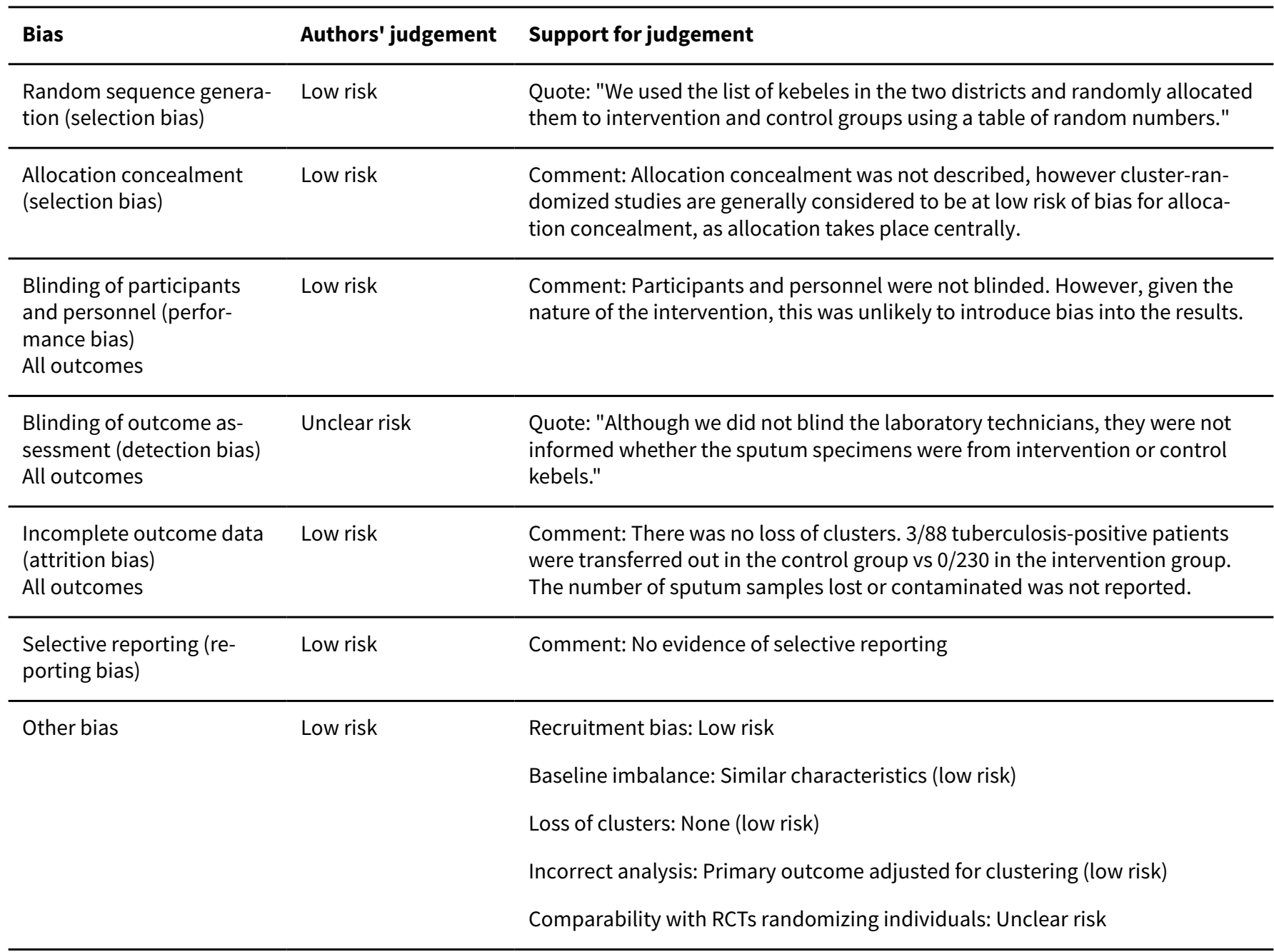




Trial design: Cluster-RCT
Unit of randomization: Primary care clinics - approximately 200 consultations per day
Number of clusters per study arm: 20
Length of follow-up: 3 months
Adjusted for cluster design: Yes

Target group: Aged 15 years and older
Total population of intervention areas: Not stated
Total number of people screened for tuberculosis in intervention areas: 1006
Exclusions: People referred urgently elsewhere
Tuberculosis screening test: Symptom screen: criteria not described
Tuberculosis diagnostic test: Sputum microscopy and mycobacteria culture

Interventions Intervention clinics: Training nurse practitioners in tuberculosis diagnosis

- Did health workers look for tuberculosis cases outside of health facilities? No.

- Were there health promotion activities to encourage people with symptoms to attend health services? No.

- Were health workers trained in tuberculosis diagnosis? Yes, nurse practitioners received between 2 and 6 educational sessions.

\section{Control clinics}

- No intervention

\begin{tabular}{|c|c|}
\hline Outcomes & $\begin{array}{l}\text { Outcomes included in the review } \\
\text { - Addional tuberculosis cases detected }\end{array}$ \\
\hline \multirow[t]{6}{*}{ Notes } & Country: South Africa \\
\hline & Setting: Urban and rural clinics at The Free State province \\
\hline & Tuberculosis prevalence: 494 per 100,000 population \\
\hline & HIV prevalence: $30.1 \%$ \\
\hline & Study dates: May to November 2013 \\
\hline & $\begin{array}{l}\text { Study sponsor: International Development Research Centre, Canada, The South African Medical Coun- } \\
\text { cil, the Free State Department of Health, and the University of Cape Town Lung Institute }\end{array}$ \\
\hline
\end{tabular}

\section{Risk of bias}

\begin{tabular}{lll}
\hline Bias & Authors' judgement & Support for judgement \\
\hline $\begin{array}{l}\text { Random sequence genera- } \\
\text { tion (selection bias) }\end{array}$ & Low risk & $\begin{array}{l}\text { Quote: "Clinics were ranked by size and allocated to intervention or control } \\
\text { arms using a random number table in blocks of four" }\end{array}$ \\
\hline $\begin{array}{l}\text { Allocation concealment } \\
\text { (selection bias) }\end{array}$ & Low risk & $\begin{array}{l}\text { Ouote: "Allocation was carried out by a trial statisticians before intervention or } \\
\text { patient recruitment" }\end{array}$ \\
\hline
\end{tabular}


Fairall 2005 ZAF (Continued)

Blinding of participants Low risk Quote: "Patients and field workers were blind to the intervention status of and personnel (performance bias)

All outcomes each clinic"

\begin{tabular}{|c|c|c|}
\hline $\begin{array}{l}\text { Blinding of outcome as- } \\
\text { sessment (detection bias) } \\
\text { All outcomes }\end{array}$ & Low risk & $\begin{array}{l}\text { Comment: Field workers screened all eligible participants leaving the clinics } \\
\text { (after they had seen the nurse). The field workers were blind to whether the } \\
\text { nurse had received the training or not. }\end{array}$ \\
\hline
\end{tabular}

All outcomes nurse had received the training or not.

Incomplete outcome data Low risk

(attrition bias)

Comment: Loss to follow-up of $7 \%$. The number of lost or missing sputum

All outcomes samples was not reported.

Selective reporting (re- Low risk Comment: No evidence of selective reporting
porting bias)

\begin{tabular}{ll}
\hline Other bias & Recruitment bias: Low risk \\
& Baseline imbalance: Similar characteristics (low risk) \\
& Loss of clusters: Unclear risk \\
& Incorrect analysis: Outcomes adjusted for clustering. \\
& Comparability with RCTs randomizing individuals: Unclear risk
\end{tabular}

Jaramillo 2001 COL

\begin{tabular}{ll} 
Methods & Trial design: Controlled before-and-after study \\
Intervention area: Cali, capital city of Valle del Cauca, Colombia \\
Control area: Riseralda, an area bordering Valle del Cauca \\
Length of follow-up: 2 years \\
\hline Participants & Target group: All ages \\
& Total population of intervention area: 2 million \\
& Total number of people screened for tuberculosis: 67,168 had smear microscopy. \\
& Exclusions: None stated. \\
& Tuberculosis screening test: None stated. \\
& Tuberculosis diagnostic test: Sputum smear microscopy
\end{tabular}

\section{Interventions Intervention clinics: Mass media tuberculosis health promotion}

- Did health workers look for tuberculosis cases outside of health facilities? No.

- Were there health promotion activities to encourage people with symptoms to attend health services? Yes, a mass media campaign using television and radio public service announcements and chat shows, and newspaper flyers and feature articles.

- Were health workers trained in tuberculosis diagnosis? Yes, but no details given and no different from control areas.

\section{Control group}

- No intervention 


Country: Colombia
Setting: Urban
Tuberculosis prevalence: 35 per 100,000 population
HIV prevalence: Not stated
Study dates: January 1993 to January 1995
Study sponsors: Not stated

\section{Risk of bias}

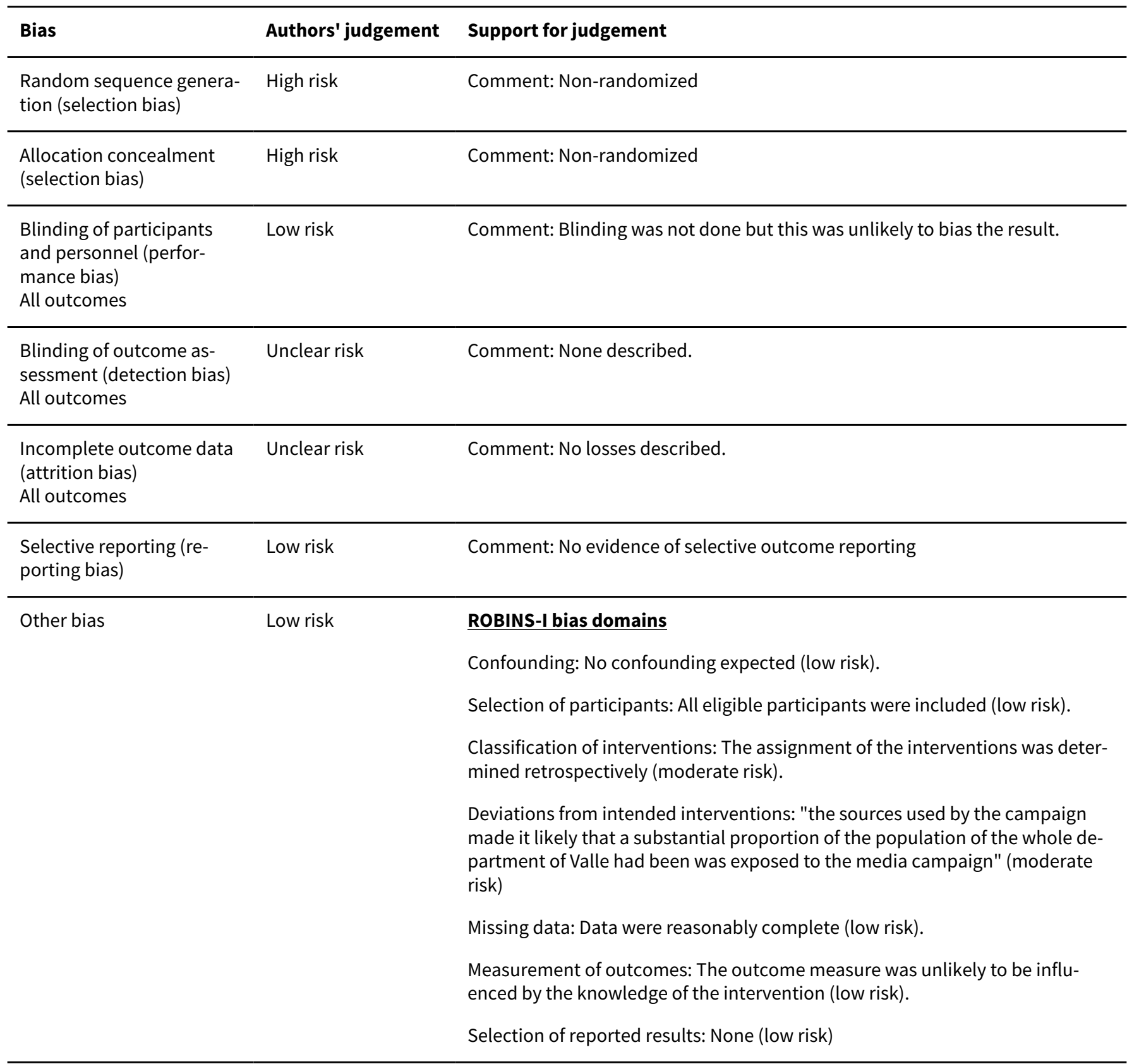


Joshi 2015 NPL

\begin{tabular}{ll}
\hline Methods & Trial design: Non-RCT (retrospective review of records) \\
Intervention area: 7 out of 10 districts where the intervention was implemented \\
Control area: 7 districts chosen on the basis of size and population \\
Length of follow-up: 1 year \\
\hline Parget group: Children aged 0 to 14 years \\
Total population of intervention area: Approximately $1,489,785$ children \\
Total number of people screened for tuberculosis in intervention area: 16,740 \\
Exclusions: None stated. \\
Tuberculosis screening test: Symptom screening \\
Tuberculosis diagnostic test: Sputum smear microscopy for AFB, chest radiography, and tuberculin \\
skin test
\end{tabular}

\section{Intervention areas}

- Did health workers look for tuberculosis cases outside of health facilities? Yes, household contact tracing, mobile chest camps in hard-to-reach areas, home visits for children with HIV, and screening at schools and safe motherhood clinics

- Were there health promotion activities to encourage people with symptoms to attend health services? Yes, through safe motherhood services

- Were health workers trained in tuberculosis diagnosis? Not described

\section{Control areas}

- No intervention

\section{Outcomes Outcomes included in the review}

- Additional tuberculosis cases

- Change in case registration rate per 100,000

Country: Nepal
Setting: Not specified
Tuberculosis prevalence: Not stated
HIV prevalence: Not stated
Study dates: March 2013 to March 2014
Study sponsor: The Union (Paris, France), MSF (Brussels Operational Centre, Luxembourg), the Depart-
ment for International Development (UK), and the World Health Organization.

\section{Risk of bias}

\begin{tabular}{lll}
\hline Bias & Authors' judgement & Support for judgement \\
\hline $\begin{array}{l}\text { Random sequence genera- } \\
\text { tion (selection bias) }\end{array}$ & High risk & Comment: Not randomized \\
\hline $\begin{array}{l}\text { Allocation concealment } \\
\text { (selection bias) }\end{array}$ & High risk & Comment: Not randomized \\
\hline
\end{tabular}


Joshi 2015 NPL (Continued)

Blinding of participants Low risk Comment: No blinding of participants and healthcare workers, however there and personnel (perforis low risk of this causing any bias. mance bias)

All outcomes

\begin{tabular}{lll}
\hline $\begin{array}{l}\text { Blinding of outcome as- } \\
\text { sessment (detection bias) }\end{array}$ & Unclear risk & Comment: Not described \\
All outcomes & & \\
\hline $\begin{array}{l}\text { Incomplete outcome data } \\
\text { (attrition bias) }\end{array}$ & Unclear risk & Comment: Not described \\
All outcomes & &
\end{tabular}

Selective reporting (re- Low risk Comment: No evidence of selective outcome reporting
porting bias)

Other bias High risk $\quad$ ROBINS-I bias domains

Confounding: Residual confounding of the population prognostic factors that determined the intervention (serious risk).

Selection of participants: "the intervention districts were selected on the basis of poverty, higher population density and lower notification rates of childhood TB case finding" (serious risk)

Classification of interventions: The assignment of the interventions was determined retrospectively for (moderate risk).

Deviations from intended interventions: No deviations from the interventions (low risk)

Missing data: Data were reasonably complete (low risk).

Measurement of outcomes: The outcome measure was unlikely to be influenced by the knowledge of the intervention (low risk).

Selection of reported results: None (low risk)

\section{Khan 2012 PAK}

Trial design: Non-RCT
Intervention area: A section of Karachi, Pakistan (lower-income households)
Control area: An adjacent section of Karachi
Length of follow-up: 12 months

Participants

Target group: All ages

Total population of intervention area: 915,767

Total number of people screened for tuberculosis in intervention area: 469,896

Exclusions: None

Tuberculosis screening test: Cough for $>3$ weeks or productive cough for $>2$ weeks

Tuberculosis diagnostic test: Sputum smear, GeneXpert, or chest X-ray 
Khan 2012 PAK (Continued)

Interventions

\section{Intervention areas: Health promotion and screening at health centres}

- Did health workers look for tuberculosis cases outside of health facilities? No, lay people were trained to screen patients at family clinics and outpatient departments.

- Were there health promotion activities to encourage people with symptoms to attend health services? Yes, billboards, cable television advertisements, posters, flyers.

- Were health workers trained in tuberculosis diagnosis? Yes, screeners were trained on tuberculosis awareness and screening.

- Other activities? Screeners received financial incentives and were supervised by experienced community health workers.

\section{Control areas}

- No intervention

Notes
Setting: Primary healthcare clinics (family clinics) and outpatient departments in Karachi
Tuberculosis prevalence: 364 per 100,000 population
HIV prevalence: Not reported
Study dates: 3 January 2010 to 31 December 2011
Study sponsor: TB REACH initiative of the Stop TB Partnership

Risk of bias

\begin{tabular}{|c|c|c|}
\hline Bias & Authors' judgement & Support for judgement \\
\hline $\begin{array}{l}\text { Random sequence genera- } \\
\text { tion (selection bias) }\end{array}$ & High risk & Comment: Not randomized, so susceptible to confounding by site \\
\hline $\begin{array}{l}\text { Allocation concealment } \\
\text { (selection bias) }\end{array}$ & High risk & Comment: Not randomized, so susceptible to confounding by site \\
\hline $\begin{array}{l}\text { Blinding of participants } \\
\text { and personnel (perfor- } \\
\text { mance bias) } \\
\text { All outcomes }\end{array}$ & Low risk & $\begin{array}{l}\text { Comment: No blinding of patients or health workers. However, this was unlike- } \\
\text { ly to bias the result. }\end{array}$ \\
\hline $\begin{array}{l}\text { Blinding of outcome as- } \\
\text { sessment (detection bias) } \\
\text { All outcomes }\end{array}$ & Low risk & $\begin{array}{l}\text { Comment: Similar assessment of the outcomes retrospectively by the tubercu- } \\
\text { losis programme investigators with no blinding }\end{array}$ \\
\hline $\begin{array}{l}\text { Incomplete outcome data } \\
\text { (attrition bias) } \\
\text { All outcomes }\end{array}$ & Unclear risk & Comment: No comment on missing outcome data \\
\hline
\end{tabular}


Khan 2012 PAK (Continued)

Selective reporting (re- Low risk Comment: No evidence of selective reporting
porting bias)

Other bias Low risk ROBINS-I bias domains

Confounding: No confounding (low risk)

Selection of participants: All eligible study participants were included in the study (low risk).

Classification of interventions: Intervention status was well defined (low risk).

Deviations from intended interventions: "Because several components were implemented simultaneously, we are unable to determine which one contributed most to the observed effect, and whether any one of the components in isolation would have had a substantial effect" (moderate risk)

Missing data: None reported (low risk).

Measurement of outcomes: Assessment of the outcome was comparable across the groups (low risk).

Selection of reported results: No selective reporting (low risk)

$\begin{array}{ll}\text { Methods } & \text { Trial design: Quasi-experimental exploratory study } \\ & \text { Intervention area: Punjab province in Pakistan } \\ \text { Control area: } 8 \text { control districts } \\ \text { Length of follow-up: } 9 \text { months } \\ \text { Target group: All ages } \\ \text { Total population of intervention area: } 662,249 \\ \text { Total number of people screened for tuberculosis in intervention area: } 662,249 \\ \text { Exclusions: None } \\ \text { Tuberculosis screening test: Tuberculosis symptom screening } \\ \text { Tuberculosis diagnostic test: Sputum smear microscopy }\end{array}$

Interventions

\section{Intervention areas: Health promotion and screening at health centres}

- Where healthcare workers trained in tuberculosis management and diagnosis? Yes, 1) joint review of the participating facilities, reviewing the input availability, case management practices and indicator analysis of respective facilities, and 2) progress review and action plan of the diagnostic centre

- Other activities? Developing the intervention monitoring guidelines and tools, which was done using a technical working group process that involved the national tuberculosis control programme

\section{Control areas: No intervention}

\section{Outcomes Outcomes included in the review}

- Additional tuberculosis cases detected (microbiologically confirmed)

- Early default (prior to commencing treatment) 
Khan 2016 PAK (Continued)

Notes
Setting: Outpatient departments in Punjab
Tuberculosis prevalence: Not mentioned
HIV prevalence: Not mentioned
Study dates: April 2007 to January 2008
Study sponsor: UK aid

\section{Risk of bias}

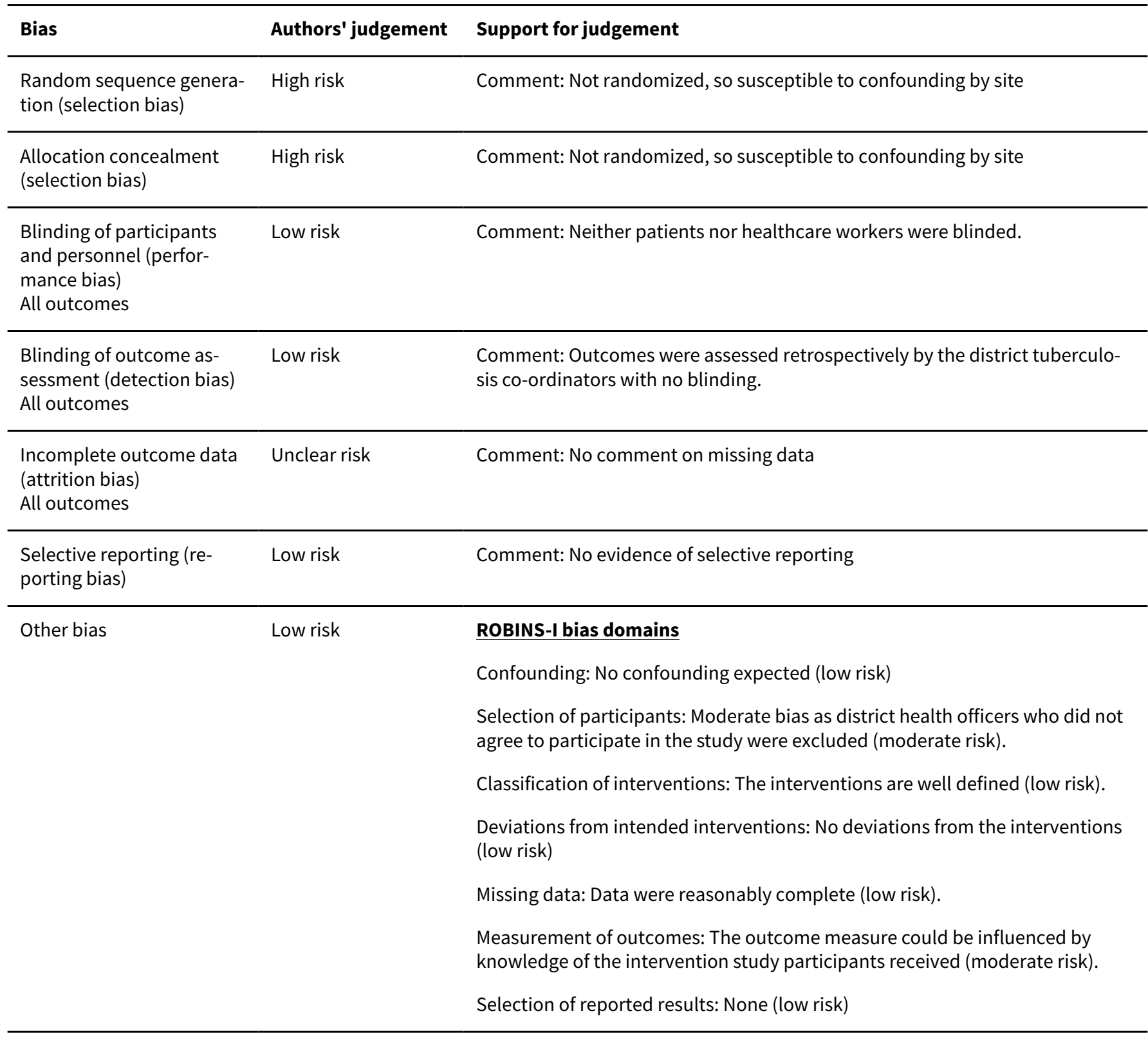


Miller 2010 BRA

\begin{tabular}{ll}
\hline Methods & Trial design: Cluster-RCT \\
& Unit of randomization: Neighbourhoods \\
& Number of clusters per study arm: 7 (total 15 clusters including 1 control) \\
& Length of follow-up: 283 days \\
& Adjusted for cluster design: Yes \\
& Study areas: A large favela in Rio de Janeiro, Brazil
\end{tabular}

Participants

Target group: Adults aged $>18$ years

Sample size: 58,587

Exclusions: None described.

Tuberculosis screening test: Cough for $>3$ weeks (as part of a 7-question tuberculosis symptom survey)

Tuberculosis diagnostic test: Sputum sample 2 for microscopy + abnormal CXR

- Did health workers look for tuberculosis cases outside of health facilities? Yes, community health agents visited all households to conduct a symptom screen and collect a sputum sample when indicated.

- Were there health promotion activities to encourage people with symptoms to attend health services? A national television tuberculosis awareness campaign is described.

- Were health workers trained in tuberculosis diagnosis? No specific training is described.

- Other activities? No other activities

\section{Intervention 2: Informational pamphlet}

- Did health workers look for tuberculosis cases outside of health facilities? No.

- Were there health promotion activities to encourage people with symptoms to attend health services? Yes, an informational pamphlet was delivered to each household describing the symptoms of tuberculosis and encouraging attendance at local health clinics for free care.

- Were health workers trained in tuberculosis diagnosis? No specific training is described.

- Other activities? None

$\begin{array}{ll}\text { Outcomes } & \text { Outcomes included in the review } \\ \text { - Additional tuberculosis cases } \\ \text { - Time to diagnosis } \\ \text { - Treatment completion } \\ \text { Country: Brazil } \\ \text { Setting: Urban slums } \\ \text { Tuberculosis incidence: } 565 \text { per } 100,000 \text { population } \\ \text { HIV prevalence: not stated } \\ \text { Study dates: } 2005 \text { to } 2006 \\ \text { Study sponsor: United States Agency for International Development and National Institutes of Health } \\ \text { grants }\end{array}$

\section{Risk of bias}

Interventions to increase tuberculosis case detection at primary healthcare or community-level services (Review) 
Miller 2010 BRA (Continued)

Bias Authors' judgement Support for judgement

Random sequence genera- Low risk tion (selection bias)

Comment: "14 neighbourhoods were matched into seven pairs with similar 2004 case notification rates using a constrained randomization scheme with a relative difference of $5 \%$ between marginal rates. One of these permutations was selected at random using MS Excel's RAND command (MicroSoft, Redmond, WA, USA)."

Allocation concealment Unclear risk Comment: None described.
(selection bias)

Blinding of participants Unclear risk Comment: None described.
and personnel (perfor-
mance bias)
All outcomes

Blinding of outcome as- Unclear risk Comment: None described.
sessment (detection bias) All outcomes

Incomplete outcome data Unclear risk Comment: None described.
(attrition bias)

All outcomes

Selective reporting (re- Low risk Comment: No evidence of selective outcome reporting

\begin{tabular}{ll}
\hline Other bias & Recruitment bias: Low risk \\
& Baseline imbalance: Matched study with similar characteristics (low risk) \\
& Loss of clusters: Low risk \\
& $\begin{array}{l}\text { Incorrect analysis: Primary outcome not adjusted for clustering, Cochrane Re- } \\
\text { view adjusts for this (low risk). } \\
\text { Comparability with RCTs randomizing individuals: Unclear risk }\end{array}$ \\
\hline
\end{tabular}

\section{Morishita 2016 KHM}

\begin{tabular}{ll}
\hline Methods & Trial design: Quasi-experimental cluster-randomized trial \\
& Unit of randomization: Operational district (OD) with estimated population of 100,000 to 200,000 \\
& Number of clusters per study arm: 15 ODs \\
& Length of follow-up: 1 year \\
& Study areas: Cambodia, selected 30 of the 71 ODs. \\
\hline Participants & Target group: All ages \\
& Target population in the intervention: 2.9 million people \\
& Exclusions: None \\
& Tuberculosis screening test: Tuberculosis symptoms screening (cough, fever, weight loss, and/or night \\
sweats of more than 2 weeks)
\end{tabular}


Morishita 2016 KHM (Continued)

Tuberculosis diagnostic test: CXR, clinical diagnosis, and Gene Xpert/MTB RIF

\section{Interventions Intervention: House-to-house visits}

- Did health workers look for tuberculosis cases outside of health facilities? Yes, trained healthcare workers and community volunteers conducted house-to-house visits.

\section{Group 2: No intervention}

- Tuberculosis was diagnosed as per national guidelines of self referral patients.

\begin{tabular}{ll}
\hline Outcomes & Outcomes included in the review \\
- Additional tuberculosis cases starting treatment \\
- Additonal tuberculosis cases detected (microbiologically confirmed) \\
\hline Country: Cambodia \\
Setting: Urban/rural \\
Tuberculosis incidence: 715 people with tuberculosis per 100,000 population \\
HIV prevalence: Not mentioned \\
Study dates: Year 1, February to December 2012; Year 2, May 2013 to March 2014 \\
Study sponsor: Government of Japan through Ministry of Health, Labour and Welfare and Korean Cen- \\
ters for Disease Control and Prevention, Republic of Korea
\end{tabular}

\section{Risk of bias}

\begin{tabular}{lll}
\hline Bias & Authors' judgement & Support for judgement \\
\hline $\begin{array}{l}\text { Random sequence genera- } \\
\text { tion (selection bias) }\end{array}$ & Low risk & $\begin{array}{l}\text { Comment: "These 30 ODs were randomly allocated into intervention and } \\
\text { control groups" }\end{array}$ \\
\hline $\begin{array}{l}\text { Allocation concealment } \\
\text { (selection bias) }\end{array}$ & Low risk & $\begin{array}{l}\text { Comment: Allocation concealment was not described, however cluster-ran- } \\
\text { domized studies are generally considered to be at low risk of bias for alloca- } \\
\text { tion concealment as allocation takes place centrally. }\end{array}$
\end{tabular}

Blinding of participants Low risk Comment: Participants and personnel were not blinded. However, given the and personnel (perfor- nature of the intervention, this was unlikely to introduce bias into the results.

mance bias)

All outcomes

Blinding of outcome as- Low risk sessment (detection bias)

All outcomes
Comment: No blinding was done. However, the outcome measurement was unlikely to be biased due to the need for bacteriological confirmation. Also, diagnosis of bacteriologically negative tuberculosis and extra-pulmonary tuberculosis was made by clinicians based on all available evidence on the same day of the active case finding.

Incomplete outcome data Unclear risk $\quad$ Comment: Not described
(attrition bias)

\begin{tabular}{lll}
\hline $\begin{array}{l}\text { Selective reporting (re- } \\
\text { porting bias) }\end{array}$ & Unclear risk & Comment: Not described \\
\hline Other bias & Low risk & Recruitment bias: Low risk \\
& Baseline imbalance: Not reported (unclear risk) \\
\hline
\end{tabular}


Length of follow-up: 2 years

Participants
Sample size: 4786
Exclusions: None described.
Tuberculosis screening test: Tuberculosis contact or cough/fever/weight loss or loss of appetite for $>2$
weeks
tuberculosis diagnostic test: CXR, tuberculin test, early morning gastric washing, induced sputum,
smear microscopy and culture

\section{Intervention: Home visits and record surveillance}

- Did health workers look for tuberculosis cases outside of health facilities? Yes, infants were visited at home every 3 months.

- Were there health promotion activities to encourage people with symptoms to attend health services? No.

- Were health workers trained in tuberculosis diagnosis? Unclear - not described

- Other activities? Surveillance of tuberculosis records, hospital admission lists and records, surveillance of clinical and hospital X-rays

\section{Group 2: Record surveillance only}

- Surveillance of tuberculosis records, hospital admission lists and records, surveillance of clinical and hospital X-rays

\begin{tabular}{ll}
\hline Outcomes & Outcomes included in the review \\
- Additional tuberculosis cases \\
- Mortality \\
\hline Country: South Africa \\
Setting: Rural \\
Tuberculosis incidence: 1442 per 100,000 population \\
HIV prevalence: Antenatal HIV prevalence of $12.8 \%$ in 2007 \\
Study dates: 2005 to 2008 \\
Study sponsor: Aeras Global TB Vaccine Foundation, Rockville, MD, USA
\end{tabular}

\section{Risk of bias}

Interventions to increase tuberculosis case detection at primary healthcare or community-level services (Review) 
Moyo 2012 ZAF (Continued)

\title{
Bias Authors' judgement Support for judgement
}

Random sequence genera- Low risk

tion (selection bias)

Quote: "Infants were randomised in a 1:1 ratio to Group 1 or Group 2 case finding using simple random allocation. These were assigned from a pre-generated randomisation list"

\begin{tabular}{|c|c|c|}
\hline $\begin{array}{l}\text { Allocation concealment } \\
\text { (selection bias) }\end{array}$ & Low risk & $\begin{array}{l}\text { Quote: "After obtaining consent from a parent or legal guardian, field workers } \\
\text { telephoned the study administrator for the infant's randomisation group and } \\
\text { study number" }\end{array}$ \\
\hline
\end{tabular}

\begin{tabular}{ll}
\hline $\begin{array}{l}\text { Blinding of participants } \\
\text { and personnel (perfor- }\end{array}$ & Low risk \\
mance & However, this was unlikely to have biased the outcomes.
\end{tabular}

mance bias)

All outcomes

\begin{tabular}{|c|c|c|}
\hline $\begin{array}{l}\text { Blinding of outcome as- } \\
\text { sessment (detection bias) }\end{array}$ & Low risk & $\begin{array}{l}\text { Quote: "CXRs were reviewed independently by a panel of three paediatric radi- } \\
\text { ologists who were blinded to the clinical information" }\end{array}$ \\
\hline
\end{tabular}

All outcomes

\begin{tabular}{|c|c|c|}
\hline $\begin{array}{l}\text { Incomplete outcome data } \\
\text { (attrition bias) }\end{array}$ & Low risk & $\begin{array}{l}\text { Comment: Moderate losses to follow-up but evenly spread across groups: } \\
14.7 \% \text { intervention versus } 15.3 \% \text { control group. }\end{array}$ \\
\hline
\end{tabular}

All outcomes

\begin{tabular}{lll}
\hline $\begin{array}{l}\text { Selective reporting (re- } \\
\text { porting bias) }\end{array}$ & Low risk & Comment: No evidence of selective reporting \\
\hline Other bias & Low risk & Comment: None noted. \\
\hline
\end{tabular}

\section{Oshi 2016 NGA}

Trial design: Prospective controlled before-and-after study
Intervention area: 6 states of Southern Nigeria
Control area: 6 states matched by "in most respects"
Length of follow-up: 1 year

\section{Participants}

\author{
Target group: Children aged less than 15 years \\ Total population of intervention area: $14,742,185$ children
}

Total number of people screened for tuberculosis in intervention area: 36,214 children

Exclusions: None stated.

Tuberculosis screening test: A symptom screen

Tuberculosis diagnostic test: Sputum smear, Keith Edwards child tuberculosis score

\section{Intervention areas}

- Did health workers look for tuberculosis cases outside of health facilities? Yes, screening of home contacts

- Were there health promotion activities to encourage people with symptoms to attend health services? Yes, 6000 handbills were distributed in hospitals, schools, and homes; 1500 posters were distributed to communities, schools, and health facilities; and there were 20 visits to primary schools to provide education. 
Oshi 2016 NGA (Continued)

- Were health workers trained in tuberculosis diagnosis? Yes, 120 medical officers and 150 nurses were trained in diagnosis and using job aids.

- Other activities? 5000 units of PPD were distributed. Screening was also conducted at outpatient clinics and ART clinics.

\section{Control areas}

- No intervention

\section{Outcomes Outcomes included in the review}

- Additional tuberculosis cases in the intervention areas. Data from the control areas were not presented.

Country: Nigeria
Setting: Not specified
Tuberculosis prevalence: Not stated
HIV prevalence: Not stated
Study dates: 1 July 2013 to 30 June 2014
Study sponsor: Canadian International Development Agency

\section{Risk of bias}

\begin{tabular}{lll}
\hline Bias & Authors' judgement & Support for judgement \\
\hline $\begin{array}{l}\text { Random sequence genera- } \\
\text { tion (selection bias) }\end{array}$ & High risk & Comment: Not randomized \\
\hline $\begin{array}{l}\text { Allocation concealment } \\
\text { (selection bias) }\end{array}$ & High risk & Comment: Not randomized \\
\hline $\begin{array}{l}\text { Blinding of participants } \\
\begin{array}{l}\text { and personnel (perfor- } \\
\text { mance bias) }\end{array}\end{array}$ & Low risk \\
All outcomes & & $\begin{array}{l}\text { Comment: Participants and personnel were not blinded, however there was a } \\
\text { low risk of bias. }\end{array}$ \\
\hline
\end{tabular}

\begin{tabular}{lll}
\hline $\begin{array}{l}\text { Blinding of outcome as- } \\
\text { sessment (detection bias) } \\
\text { All outcomes }\end{array}$ & Unclear risk & Comment: Not described \\
\hline $\begin{array}{l}\text { Incomplete outcome data } \\
\text { (attrition bias) } \\
\text { All outcomes }\end{array}$ & Unclear risk & Comment: Not described \\
\hline $\begin{array}{l}\text { Selective reporting (re- } \\
\text { porting bias) }\end{array}$ & Unclear risk & $\begin{array}{l}\text { Comment: Tuberculosis cases detected in the control areas were not clearly } \\
\text { reported. }\end{array}$
\end{tabular}

\begin{tabular}{ll}
\hline Other bias & $\underline{\text { ROBINS-I bias domains }}$ \\
& Confounding: None expected (low risk). \\
& Selection of participants: All eligible participants were included (low risk). \\
& $\begin{array}{l}\text { Classification of interventions: Facilities with highest number of children were } \\
\text { purposefully selected (moderate risk). }\end{array}$
\end{tabular}


Deviations from intended interventions: Some of the interventions were not noted, though their impact is limited (moderate risk).

Missing data: Expected to have similar missing data (low risk)

Measurement of outcomes: The outcome measure could be minimally influenced by knowledge of the intervention (moderate risk).

Selection of reported results: None (low risk)

\section{Reddy 2015 IND}

Trial design: Controlled before-and-after study
Intervention area: 20 designated microscopy centres (which serve vulnerable populations)
Control area: 11 designated microscopy centres (which serve less vulnerable populations)
Length of follow-up: 6 months

Participants

Target group: Adults and children from vulnerable communities

Total population of intervention area: Approximately 2 million

Total number of people screened for tuberculosis in intervention area: 8468/115,119 households were visited.

Exclusions: None stated.

Tuberculosis screening test: "presumptive" - probably clinical criteria

Tuberculosis diagnostic test: Sputum smear

Interventions

\section{Intervention areas}

- Did health workers look for tuberculosis cases outside of health facilities? Yes, trained community volunteers visited the homes of people in vulnerable communities.

- Were there health promotion activities to encourage people with symptoms to attend health services? Yes, information, education, and communication materials were given to each visited house.

- Were health workers trained in tuberculosis diagnosis? Yes, volunteers described as "trained".

\section{Control areas}

- Standard facility-based care

Outcomes Outcomes included in the review

- Additional tuberculosis cases detected

Notes Country: India

Setting: 2 districts of Karnataka in Southern India

Tuberculosis prevalence: Not stated

HIV prevalence: Not stated

Study dates: July to December 2013 compared to July to December 2012

Study sponsor: United States Agency for International Development (USAID) 
Reddy 2015 IND (Continued)

Risk of bias

\begin{tabular}{|c|c|c|}
\hline Bias & Authors' judgement & Support for judgement \\
\hline $\begin{array}{l}\text { Random sequence genera- } \\
\text { tion (selection bias) }\end{array}$ & High risk & Comment: Non-randomized trial \\
\hline $\begin{array}{l}\text { Allocation concealment } \\
\text { (selection bias) }\end{array}$ & High risk & Comment: Non-randomized trial \\
\hline $\begin{array}{l}\text { Blinding of participants } \\
\text { and personnel (perfor- } \\
\text { mance bias) } \\
\text { All outcomes }\end{array}$ & Low risk & $\begin{array}{l}\text { Comment: Participants and personnel were not blinded, however there was a } \\
\text { low risk of bias. }\end{array}$ \\
\hline $\begin{array}{l}\text { Blinding of outcome as- } \\
\text { sessment (detection bias) } \\
\text { All outcomes }\end{array}$ & Unclear risk & Comment: Not described \\
\hline $\begin{array}{l}\text { Incomplete outcome data } \\
\text { (attrition bias) } \\
\text { All outcomes }\end{array}$ & Unclear risk & Comment: Not described \\
\hline $\begin{array}{l}\text { Selective reporting (re- } \\
\text { porting bias) }\end{array}$ & Low risk & Comment: No evidence of selective reporting \\
\hline Other bias & Low risk & $\begin{array}{l}\text { ROBINS-I bias domains } \\
\text { Confounding: Confounding expected (moderate risk). } \\
\text { Selection of participants: Selected population that was vulnerable (moderate } \\
\text { risk) } \\
\text { Classification of interventions: The interventions were determined retrospec- } \\
\text { tively (moderate risk). } \\
\text { Deviations from intended interventions: None expected (low risk). } \\
\text { Missing data: Not documented (low risk) } \\
\text { Measurement of outcomes: Minimal errors related to outcome (moderate risk) } \\
\text { Selection of reported results: None (low risk) }\end{array}$ \\
\hline
\end{tabular}

\section{Shargie 2006 ETH}

\begin{tabular}{ll}
\hline Methods & Trial design: Cluster-RCT \\
& Unit of randomization: Rural communities - approximate size 11,000 people \\
& Number of clusters per study group: 12 intervention versus 20 control \\
& Length of follow-up: 6 months \\
& Adjusted for cluster design: Yes \\
\hline Participants & Target group: All ages \\
& Total population of intervention areas: 127,607
\end{tabular}


Exclusions: None stated.

Tuberculosis screening test: Symptom screening; criteria not described

Tuberculosis diagnostic test: Sputum smear microscopy

\section{Interventions Intervention: Outreach clinics and health promotion}

- Did health workers look for tuberculosis cases outside of health facilities? Yes, health workers conducted monthly outreach clinics in each kebele.

- Were there health promotion activities to encourage people with symptoms to attend health services? Yes, health promoters visited houses, distributed leaflets and posters, and promoted messages at schools and public gatherings.

- Were health workers trained in tuberculosis diagnosis? Yes, 4 days training on case finding, diagnostic procedures, handling of sputum.

\section{Group 2}

- No intervention

\begin{tabular}{ll}
\hline Outcomes & Outcomes included in the review \\
- Additional tuberculosis cases detected \\
- Tuberculosis treatment completion \\
- Default \\
\hline Cotes \\
Setting: Rural districts \\
Tuberculosis prevalence: Not stated mortality \\
HIV prevalence: Not stated \\
Study dates: 1 May 2003 to 30 April 2004 \\
Study sponsor: The Centre for International Health, University of Bergen \\
\hline
\end{tabular}

\section{Risk of bias}

\begin{tabular}{|c|c|c|}
\hline Bias & Authors' judgement & Support for judgement \\
\hline $\begin{array}{l}\text { Random sequence genera- } \\
\text { tion (selection bias) }\end{array}$ & Unclear risk & Comment: Described as "randomised"; no further details given. \\
\hline $\begin{array}{l}\text { Allocation concealment } \\
\text { (selection bias) }\end{array}$ & Unclear risk & $\begin{array}{l}\text { Comment: Not described, but usually low risk in cluster-randomized trials if } \\
\text { the sequence generation is low risk. }\end{array}$ \\
\hline $\begin{array}{l}\text { Blinding of participants } \\
\text { and personnel (perfor- } \\
\text { mance bias) } \\
\text { All outcomes }\end{array}$ & Low risk & Comment: None described, but unlikely to bias the results of the trial. \\
\hline $\begin{array}{l}\text { Blinding of outcome as- } \\
\text { sessment (detection bias) } \\
\text { All outcomes }\end{array}$ & Unclear risk & Comment: None described. \\
\hline
\end{tabular}


Shargie 2006 ETH (Continued)

Incomplete outcome data Low risk Comment: No loss of clusters. No other losses described.

(attrition bias)

All outcomes

Selective reporting (re- Low risk Comment: No evidence of selective reporting

porting bias)

Other bias Low risk Recruitment bias: Low risk

Baseline imbalance: Similar characteristics (low risk)

Loss of clusters: None (low risk)

Incorrect analysis: Primary outcome adjusted for clustering.

Comparability with RCTs randomizing individuals: Unclear risk

Talukder 2012 BGD

$\begin{array}{ll}\text { Methods } & \text { Trial design: Cluster-RCT } \\ & \text { Unit of randomization: Microscopy centres } \\ & \text { Number of clusters per study group: } 18 \\ & \text { Length of follow-up: } 12 \text { months } \\ & \text { Adjusted for cluster design: Not described }\end{array}$

Participants

Target group: Children aged less than 14 years

Total population of study areas: Not stated

Total number of people screened for tuberculosis in intervention area: 1943

Exclusions: None stated.

Tuberculosis screening test: None described.

Tuberculosis diagnostic test: Keith Edwards tuberculosis score

\section{Interventions Intervention: Training of health staff and health promotion}

- Did health workers look for tuberculosis cases outside of health facilities? No.

- Were there health promotion activities to encourage people with symptoms to attend health services? Yes, health education sessions using flip charts, posters and pamphlets at tuberculosis clubs, village doctor meetings, girl guide and boy scout meetings.

- Were health workers trained in tuberculosis diagnosis? Yes, health workers were trained to weigh children, assess severe malnutrition, perform the Mantoux test, and use the Keith Edwards Child Tuberculosis score chart.

\section{Control}

- No intervention

\section{Outcomes Outcomes included in the review}

- Additional tuberculosis cases 
Talukder 2012 BGD (Continued)

\author{
Setting: Unclear \\ Tuberculosis prevalence: 207 per 100,000 adults \\ HIV prevalence: Not reported \\ Study dates: 2007 to 2009 \\ Study sponsor: Damien Foundation Bangladesh
}

\title{
Risk of bias
}

\begin{tabular}{lll}
\hline Bias & Authors' judgement & Support for judgement \\
\hline $\begin{array}{ll}\text { Random sequence genera- } \\
\text { tion (selection bias) }\end{array}$ & Unclear risk & $\begin{array}{l}\text { Quote: "One intervention centre was randomly selected from each district, and } \\
\text { two from the larger districts containing more than the median number of cen- } \\
\text { tres. A similar number of control microscopy centres were selected in the same } \\
\text { districts" }\end{array}$ \\
& &
\end{tabular}

\begin{tabular}{|c|c|c|}
\hline $\begin{array}{l}\text { Allocation concealment } \\
\text { (selection bias) }\end{array}$ & Unclear risk & $\begin{array}{l}\text { Comment: Not described, but usually low risk for cluster-randomized trials if } \\
\text { the random sequence is low risk. }\end{array}$ \\
\hline
\end{tabular}

Blinding of participants Low risk Comment: No blinding of participants or health workers described, but this is
and personnel (perfor- unlikely to bias the results separate from the effects of the intervention.

mance bias)

All outcomes

\begin{tabular}{|c|c|c|}
\hline $\begin{array}{l}\text { Blinding of outcome as- } \\
\text { sessment (detection bias) } \\
\text { All outcomes }\end{array}$ & Unclear risk & Comment: None described. \\
\hline $\begin{array}{l}\text { Incomplete outcome data } \\
\text { (attrition bias) } \\
\text { All outcomes }\end{array}$ & Low risk & Comment: No loss of clusters occurred. No other losses reported. \\
\hline $\begin{array}{l}\text { Selective reporting (re- } \\
\text { porting bias) }\end{array}$ & Low risk & Comment: No evidence of selective reporting. \\
\hline \multirow[t]{5}{*}{ Other bias } & Low risk & Recruitment bias: Low risk \\
\hline & & Baseline imbalance: Similar characteristics (low risk) \\
\hline & & Loss of clusters: None (low risk) \\
\hline & & $\begin{array}{l}\text { Incorrect analysis: Primary outcome not adjusted for clustering, Cochrane Re- } \\
\text { view adjusts for this (low risk). }\end{array}$ \\
\hline & & Comparability with RCTs randomizing individuals: Unclear risk \\
\hline
\end{tabular}

\section{Yassin 2013 ETH}

Methods

\author{
Trial design: Non-RCT \\ Intervention area: Sidima zone, Southern Ethiopia \\ Control area: Hadiya zone, Southern Ethiopia \\ Length of follow-up: 14 months
}


Yassin 2013 ETH (Continued)
Participants
Target group: All ages
Total population of intervention area: Over 3 million
Total number of people screened for tuberculosis in intervention area: Not stated
Exclusions: None stated.
Tuberculosis screening test: Symptom screen: cough $>2$ weeks
Tuberculosis diagnostic test: Sputum smear microscopy

Interventions

Intervention areas: Training of health extension workers to visit houses and screen for tuberculosis

- Did health workers look for tuberculosis cases outside of health facilities? Yes, health extension workers went house to house using a symptom screen.

- Were there health promotion activities to encourage people with symptoms to attend health services? Yes, community meetings, campaigns, and local radio.

- Were health workers trained in tuberculosis diagnosis? Yes, health extension workers were trained to screen for chronic cough and collect, store, and transport sputum samples.

- Additional activities: Awareness creation workshops for political, community, and religious leaders, teachers and other stakeholders. Improvement in laboratory services, and supervision of health extension workers.

\section{Control areas: No intervention}

- Health extension workers did not receive training, but provided health services including health education about tuberculosis to people in their kebeles.

\begin{tabular}{|c|c|c|}
\hline Outcomes & \multicolumn{2}{|c|}{$\begin{array}{l}\text { Outcomes included in the review } \\
\text { - Additional tuberculosis cases } \\
\text { - Tuberculosis cure } \\
\text { - Treatment completion } \\
\text { - Early default (prior to commencing treatment or during the intensive phase of treatment) } \\
\text { - Tuberculosis mortality }\end{array}$} \\
\hline Notes & $\begin{array}{l}\text { Country: Ethiopia } \\
\text { Setting: Community b } \\
\text { Tuberculosis prevalen } \\
\text { HIV prevalence: Not st } \\
\text { Study dates: October } \\
\text { Study sponsor: TB RE } \\
\text { ternational Developm }\end{array}$ & $\begin{array}{l}127 \text { per } 100,000 \text { population } \\
10 \text { to December } 2011 \\
\text { Initiative of the Stop TB Partnership (through a grant from the Canadian In- } \\
\text { t Agency) }\end{array}$ \\
\hline \multicolumn{3}{|l|}{ Risk of bias } \\
\hline Bias & Authors' judgement & Support for judgement \\
\hline $\begin{array}{l}\text { Random sequence genera- } \\
\text { tion (selection bias) }\end{array}$ & High risk & Comment: Not randomized \\
\hline $\begin{array}{l}\text { Allocation concealment } \\
\text { (selection bias) }\end{array}$ & High risk & Comment: Not randomized \\
\hline
\end{tabular}


Yassin 2013 ETH (Continued)

Blinding of participants Low risk Comment: Health workers and populations were not blind to the allocation, and personnel (perforbut this was unlikely to bias the effect of the intervention. mance bias)

All outcomes

$\begin{array}{ll}\text { Blinding of outcome as- } & \text { High risk }\end{array}$ Comment: No blinding of outcome assessors

All outcomes

Incomplete outcome data Unclear risk

Comment: The number of lost or invalid sputum smears was not reported.

(attrition bias)

All outcomes

Selective reporting (re- Low risk Comment: No evidence of selective reporting
porting bias)

\begin{tabular}{lll}
\hline Other bias $\quad$ Low risk & ROBINS-I bias domains
\end{tabular}

Confounding: Minimal confounding (moderate risk)

Selection of participants: All study participants were included (low risk).

Classification of interventions: Intervention status is well defined (low risk).

Deviations from intended interventions: None expected (low risk).

Missing data: None (low risk)

Measurement of outcomes: Comparable between groups (low risk)

Selection of reported results: None (low risk)

Abbreviations: AFB: acid-fast bacilli; ART: antiretroviral therapy; BCG: bacille Calmette-Guerin; CXR: chest X-ray; PPD: purified protein derivative; RCT: randomized controlled trial; TB: tuberculosis.

Characteristics of excluded studies [ordered by study ID]

\begin{tabular}{ll}
\hline Study & Reason for exclusion \\
\hline Abdurrahman 2017 & No community-level interventions \\
\hline Ade 2016 & No community-level interventions \\
\hline Adejumo 2016 & No parallel control group \\
\hline Anger 2012 & No parallel control group \\
\hline Arora 2004 & $\begin{array}{l}\text { No parallel control group reported. A control area is described, but TB outcomes are only reported } \\
\text { for the area with the intervention. }\end{array}$ \\
\hline Atif 2013 & No intervention to increase TB diagnosis \\
\hline Bai 2008 & No parallel control group \\
\hline Balcha 2015 & Intervention not at the primary care level. No parallel control group. \\
\hline Bassili 2011 & No intervention to increase TB diagnosis \\
\hline
\end{tabular}

Interventions to increase tuberculosis case detection at primary healthcare or community-level services (Review) 


\begin{tabular}{|c|c|}
\hline Study & Reason for exclusion \\
\hline Bernard 2012 & No parallel control group \\
\hline Bothamley 2008 & No intervention to increase TB diagnosis \\
\hline Charles 2016 & No parallel control group \\
\hline Churchyard 2011 & $\begin{array}{l}\text { No community-level interventions. This study was conducted among gold mine workers, not the } \\
\text { general population. }\end{array}$ \\
\hline Del Portillo-Mustieles 2013 & No community-level intervention \\
\hline Delva 2016 & No parallel control group \\
\hline den Boon 2008 & No parallel control group \\
\hline Dholakia 2016 & No community-level interventions \\
\hline Dobler 2016 & No community-level interventions \\
\hline Eang 2012 & No parallel control group \\
\hline Elden 2011 & No parallel control group \\
\hline Fatima 2016 & No parallel control group \\
\hline Fox 2012 & No parallel control group \\
\hline Furin 2007 & No parallel control group \\
\hline Gebi 2009 & No parallel control group \\
\hline Gilpin 1987 & No parallel control group \\
\hline Gonzalez-Ochoa 2009 & No parallel control group \\
\hline Gorbacheva 2010 & No parallel control group \\
\hline Gounder 2011 & No parallel control group \\
\hline Griffiths 2007 & Done in low-burden settings \\
\hline Hermans 2012 & No community-level intervention \\
\hline Hinderaker 2011a & $\begin{array}{l}\text { No parallel control group. This paper describes } 51 \text { individual projects that aimed to detect TB cas- } \\
\text { es. However, none of these projects had parallel control groups, and instead were compared with } \\
\text { routinely collected data from the year before. }\end{array}$ \\
\hline Hossain 2010 & No parallel control group \\
\hline Kaboru 2013 & No parallel control group \\
\hline Kakinda 2016 & No parallel control group \\
\hline Khan 2007 & No intervention to increase TB diagnosis \\
\hline
\end{tabular}




\begin{tabular}{|c|c|}
\hline Study & Reason for exclusion \\
\hline Kuznetsov 2014 & No parallel control group \\
\hline Lebina 2016 & No parallel control group \\
\hline Ntinginya 2012 & No parallel control group \\
\hline Oshi 2016 & No parallel control group \\
\hline Prasad 2016 & No parallel control group \\
\hline Pronyk 2001 & Not a TB case-finding study \\
\hline Ruutel 2011 & $\begin{array}{l}\text { Not a relevent comparison. This study screened intravenous drug users participating in a } \\
\text { methadone substitution programme for TB. It then compares active referral with passive referral. } \\
\text { Study does not compare a TB case-finding intervention with no intervention. }\end{array}$ \\
\hline Sanaie 2016 & No parallel control group \\
\hline Sekandi 2009 & No parallel control group \\
\hline Sekandi 2014 & No parallel control group \\
\hline Shapiro 2012 & $\begin{array}{l}\text { Not a relevent comparison. This study compares the prevalence of TB in houses with a TB contact } \\
\text { and houses without a TB contact. It does not compare a TB case-finding intervention with no inter- } \\
\text { vention. }\end{array}$ \\
\hline Shrivastava 2012 & No parallel control group \\
\hline Soares 2013 & No parallel control group \\
\hline Ssemmondo 2016 & No parallel control group \\
\hline Story 2012 & No parallel control group \\
\hline Szkwarko 2016 & No parallel control group \\
\hline Uwimana 2012 & No outcomes relevent to this review \\
\hline Wei 2015 & No community-level intervention. This study was done in smokers. \\
\hline Yimer 2009a & No parallel control group \\
\hline Yimer 2009b & No parallel control group \\
\hline Zhang 2011 & No parallel control group \\
\hline
\end{tabular}

Characteristics of studies awaiting assessment [ordered by study ID]

Chen 1990

\begin{tabular}{ll}
\hline Methods & Not stated \\
\hline Participants & Not stated \\
\hline
\end{tabular}


Chen 1990 (Continued)

\begin{tabular}{ll} 
Interventions & Not stated \\
\hline Outcomes & Not stated \\
\hline Notes & Not stated
\end{tabular}

Duanmu 2005

\begin{tabular}{ll}
\hline Methods & Not stated \\
\hline Participants & Not stated \\
\hline Interventions & Not stated \\
\hline Outcomes & Not stated \\
\hline Notes & Not stated \\
\hline
\end{tabular}

\section{Gadala 2015}

\begin{tabular}{|c|c|}
\hline Methods & Not stated \\
\hline Participants & Not stated \\
\hline Interventions & Not stated \\
\hline Outcomes & Not stated \\
\hline Notes & Not stated \\
\hline
\end{tabular}

\section{Grzybowski 1965}

\begin{tabular}{ll}
\hline Methods & Not stated \\
\hline Participants & Not stated \\
\hline Interventions & Not stated \\
\hline Outcomes & Not stated \\
\hline Notes & Not stated \\
\hline
\end{tabular}

Jensen 2015

\begin{tabular}{ll}
\hline Methods & Not stated \\
\hline Participants & Not stated
\end{tabular}


Jensen 2015 (Continued)

\begin{tabular}{ll} 
Interventions & Not stated \\
\hline Outcomes & Not stated \\
\hline Notes & Not stated \\
\hline
\end{tabular}

Nadu 2004

\begin{tabular}{ll}
\hline Methods & Not stated \\
\hline Participants & Not stated \\
\hline Interventions & Not stated \\
\hline Outcomes & Not stated \\
\hline Notes & Not stated \\
\hline
\end{tabular}

Poliakova 2015

\begin{tabular}{ll}
\hline Methods & Not stated \\
\hline Participants & Not stated \\
\hline Interventions & Not stated \\
\hline Outcomes & Not stated \\
\hline Notes & Not stated \\
\hline
\end{tabular}

Ursov 1970

\begin{tabular}{ll}
\hline Methods & Not stated \\
\hline Participants & Not stated \\
\hline Interventions & Not stated \\
\hline Outcomes & Not stated \\
\hline Notes & Not stated \\
\hline
\end{tabular}

DATA AND ANALYSES 
Comparison 1. Outreach tuberculosis screening versus no intervention

\begin{tabular}{|c|c|c|c|c|}
\hline Outcome or subgroup title & No. of studies & $\begin{array}{l}\text { No. of partici- } \\
\text { pants }\end{array}$ & Statistical method & Effect size \\
\hline $\begin{array}{l}1 \text { Tuberculosis cases detected (micro- } \\
\text { biologically confirmed) }\end{array}$ & 4 & 163043 & $\begin{array}{l}\text { Risk Ratio (M-H, Random, } \\
95 \% \mathrm{Cl})\end{array}$ & $1.24[0.86,1.79]$ \\
\hline $\begin{array}{l}2 \text { Tuberculosis cases detected: sub- } \\
\text { grouped by tuberculosis prevalence }\end{array}$ & 4 & 163043 & $\begin{array}{l}\text { Risk Ratio (M-H, Fixed, 95\% } \\
\mathrm{Cl})\end{array}$ & $1.16[0.92,1.46]$ \\
\hline 2.1 Prevalence $<5 \%$ & 1 & 7125 & $\begin{array}{l}\text { Risk Ratio (M-H, Fixed, 95\% } \\
\mathrm{Cl})\end{array}$ & $0.85[0.60,1.19]$ \\
\hline 2.2 Prevalence $5 \%+$ & 3 & 155918 & $\begin{array}{l}\text { Risk Ratio (M-H, Fixed, 95\% } \\
\mathrm{Cl})\end{array}$ & $1.52[1.10,2.09]$ \\
\hline $\begin{array}{l}3 \text { Tuberculosis cases detected; sub- } \\
\text { grouped by intervention }\end{array}$ & 4 & 163043 & $\begin{array}{l}\text { Risk Ratio (M-H, Random, } \\
95 \% \mathrm{Cl})\end{array}$ & $1.24[0.86,1.79]$ \\
\hline $\begin{array}{l}\text { 3.1 Outreach clinics plus health pro- } \\
\text { motion }\end{array}$ & 1 & 52405 & $\begin{array}{l}\text { Risk Ratio (M-H, Random, } \\
95 \% \mathrm{Cl})\end{array}$ & $1.28[0.76,2.17]$ \\
\hline $\begin{array}{l}3.2 \text { House-to-house screening plus } \\
\text { health promotion }\end{array}$ & 3 & 110638 & $\begin{array}{l}\text { Risk Ratio (M-H, Random, } \\
95 \% \mathrm{Cl})\end{array}$ & $1.25[0.75,2.08]$ \\
\hline $\begin{array}{l}4 \text { Tuberculosis cases detected (all } \\
\text { forms) }\end{array}$ & 1 & 28704 & $\begin{array}{l}\text { Risk Ratio (M-H, Fixed, 95\% } \\
\mathrm{Cl})\end{array}$ & $1.28[0.83,1.98]$ \\
\hline 5 Tuberculosis treatment default & 3 & 849 & $\begin{array}{l}\text { Risk Ratio (M-H, Fixed, 95\% } \\
\mathrm{Cl})\end{array}$ & $0.67[0.47,0.96]$ \\
\hline 6 Tuberculosis treatment success & 3 & 849 & $\begin{array}{l}\text { Risk Ratio (M-H, Fixed, 95\% } \\
\text { Cl) }\end{array}$ & $1.07[1.00,1.15]$ \\
\hline 7 Tuberculosis treatment failure & 3 & 849 & $\begin{array}{l}\text { Risk Ratio (M-H, Fixed, 95\% } \\
\mathrm{Cl})\end{array}$ & $1.57[0.50,4.92]$ \\
\hline 8 Tuberculosis mortality & 3 & 849 & $\begin{array}{l}\text { Risk Ratio (M-H, Fixed, 95\% } \\
\mathrm{Cl})\end{array}$ & $0.99[0.43,2.25]$ \\
\hline 9 Long-term tuberculosis prevalence & 1 & & Risk Ratio (Fixed, 95\% Cl) & $1.14[0.65,2.00]$ \\
\hline
\end{tabular}

Analysis 1.1. Comparison 1 Outreach tuberculosis screening versus no intervention, Outcome 1 Tuberculosis cases detected (microbiologically confirmed).

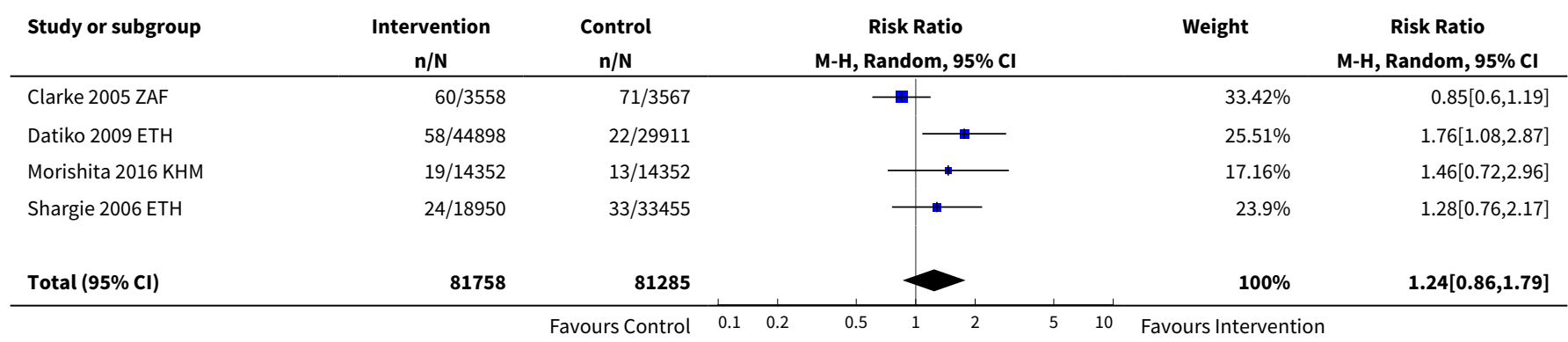




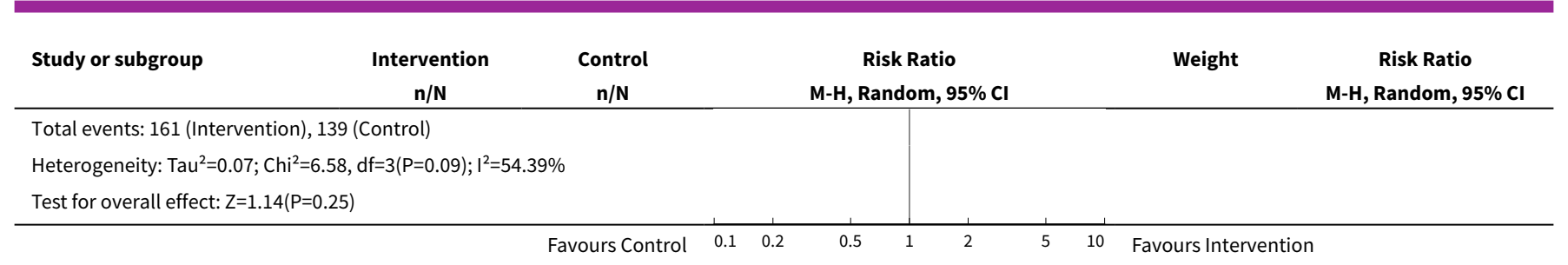

\section{Analysis 1.2. Comparison 1 Outreach tuberculosis screening versus no intervention, Outcome 2 Tuberculosis cases detected: subgrouped by tuberculosis prevalence.}

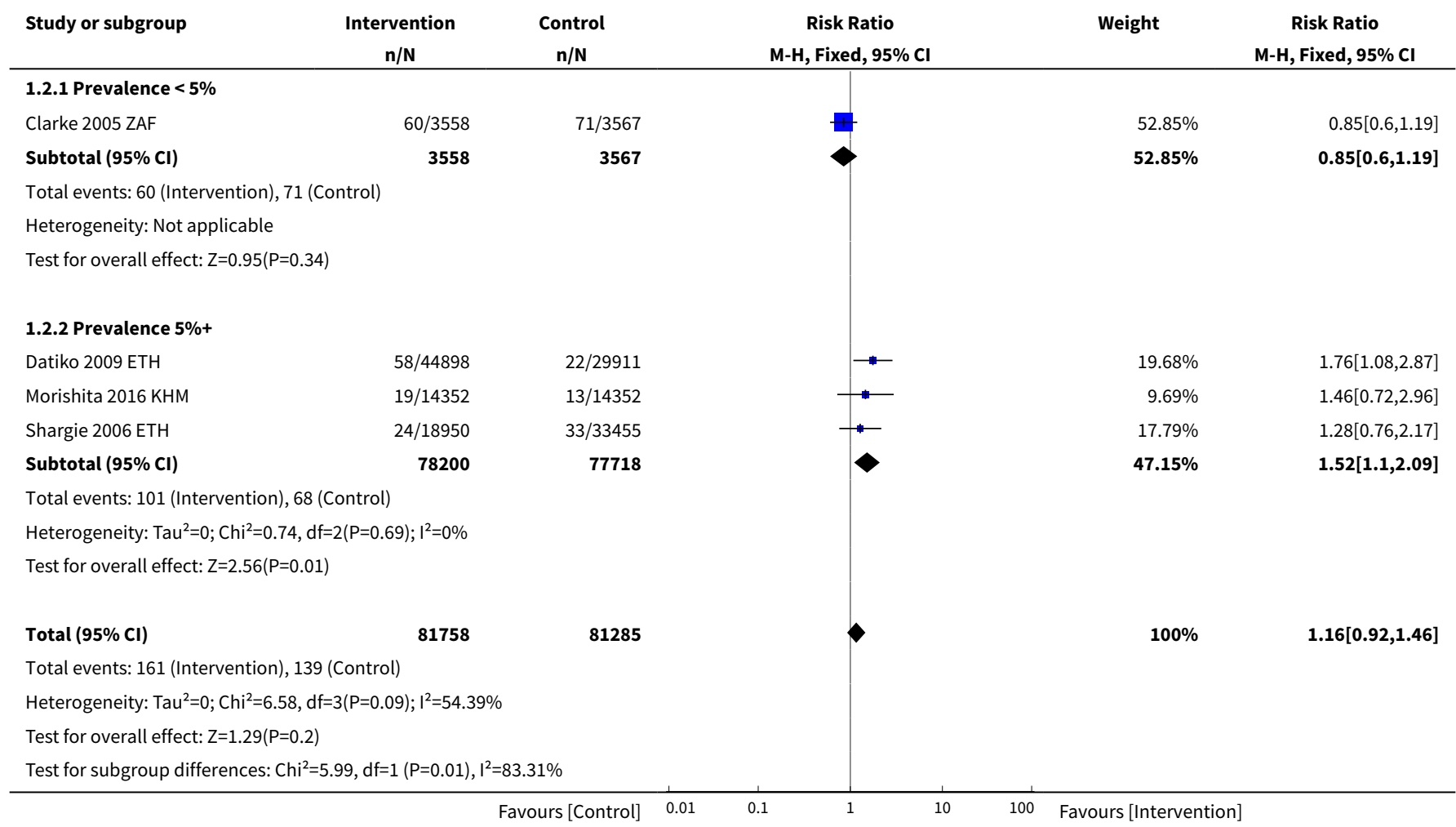

Analysis 1.3. Comparison 1 Outreach tuberculosis screening versus no intervention, Outcome 3 Tuberculosis cases detected; subgrouped by intervention.

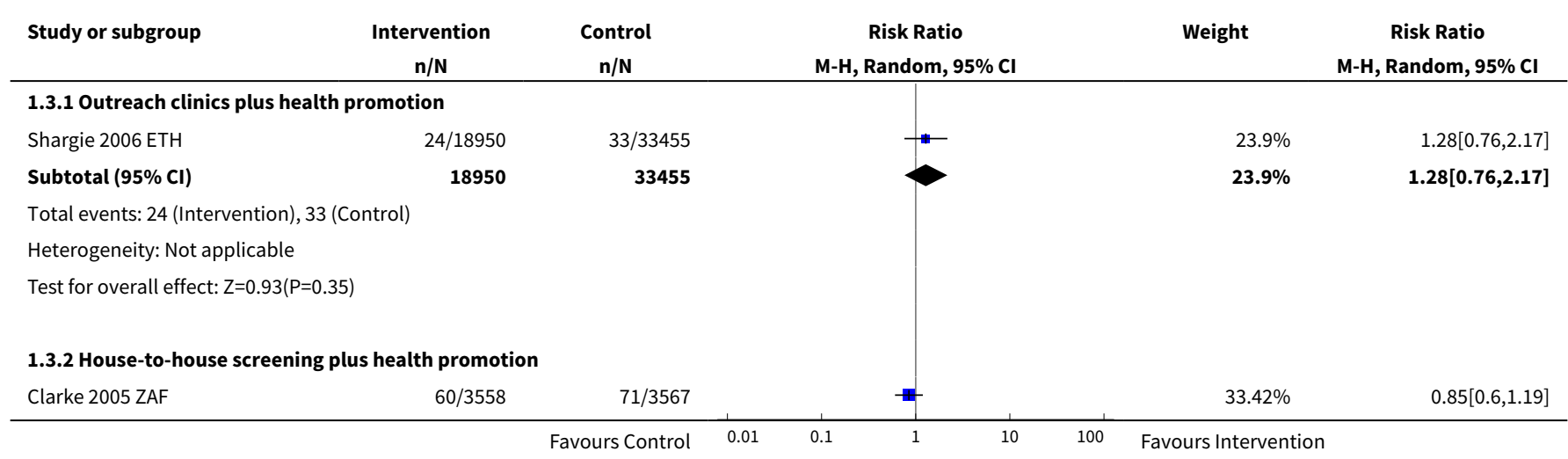




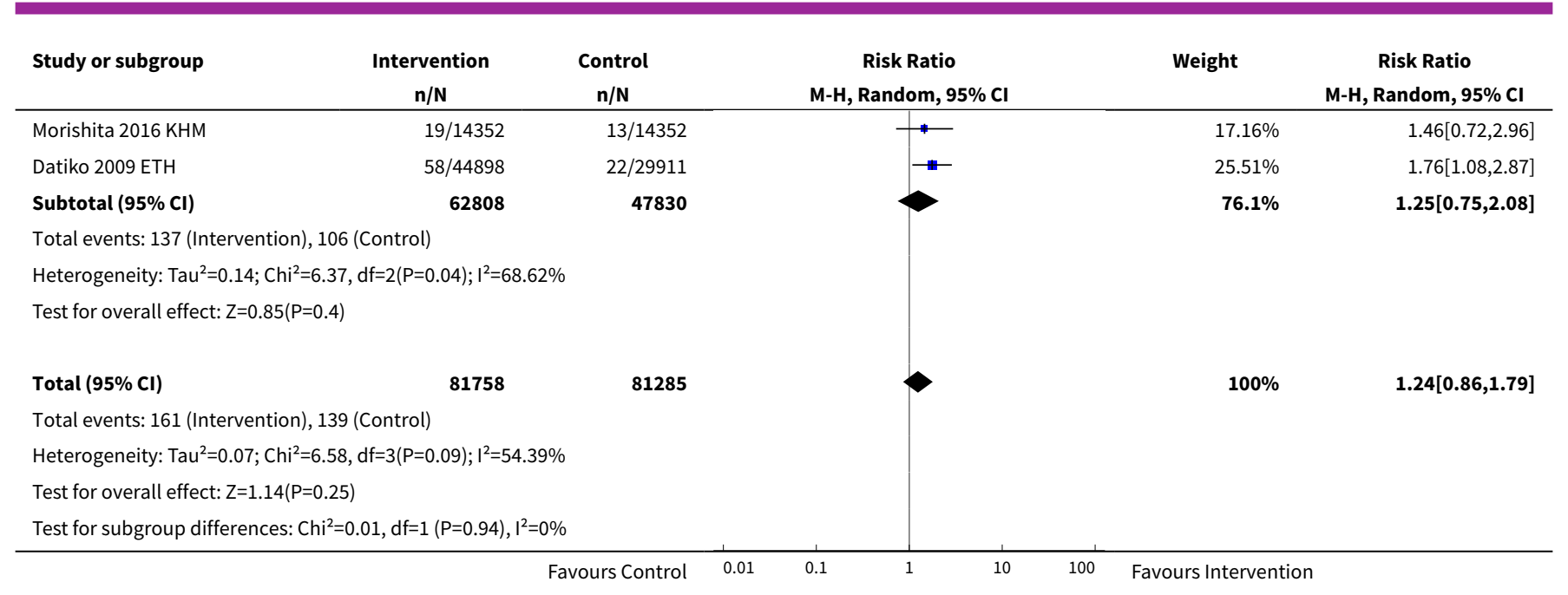

Analysis 1.4. Comparison 1 Outreach tuberculosis screening versus no intervention, Outcome 4 Tuberculosis cases detected (all forms).

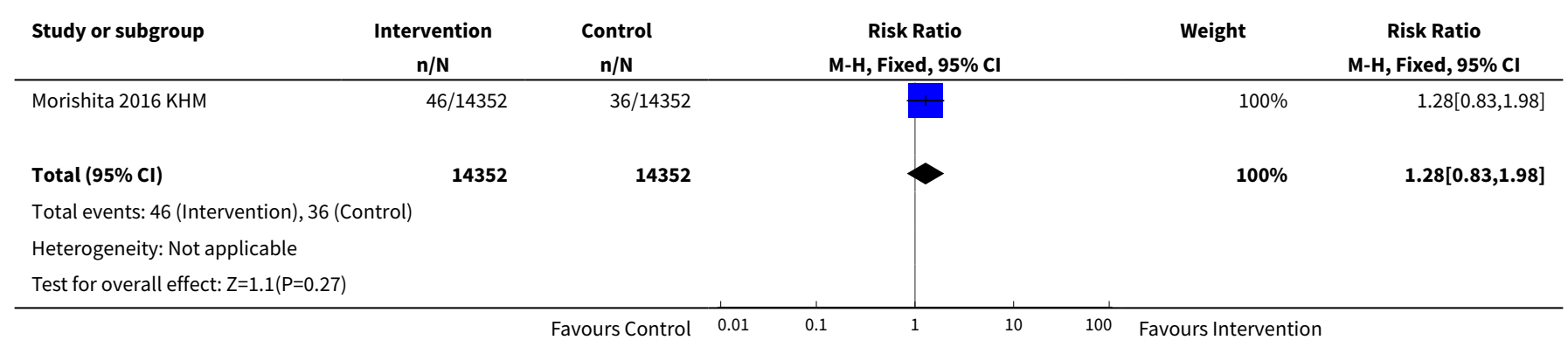

Analysis 1.5. Comparison 1 Outreach tuberculosis screening versus no intervention, Outcome 5 Tuberculosis treatment default.

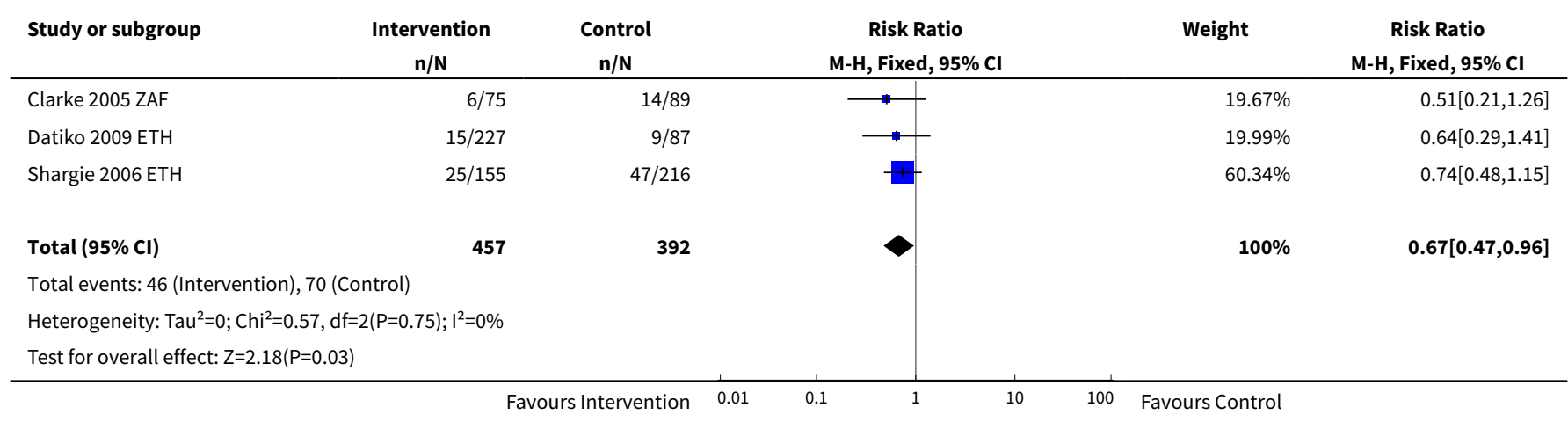


Analysis 1.6. Comparison 1 Outreach tuberculosis screening versus no intervention, Outcome 6 Tuberculosis treatment success.

\begin{tabular}{|c|c|c|c|c|c|}
\hline Study or subgroup & $\begin{array}{c}\text { Intervention } \\
n / N\end{array}$ & $\begin{array}{c}\text { Control } \\
n / N\end{array}$ & $\begin{array}{c}\text { Risk Ratio } \\
\text { M-H, Fixed, 95\% Cl }\end{array}$ & Weight & $\begin{array}{c}\text { Risk Ratio } \\
\text { M-H, Fixed, } 95 \% \mathrm{Cl}\end{array}$ \\
\hline Clarke 2005 ZAF & $61 / 75$ & $67 / 89$ & \begin{tabular}{l|l} 
\\
\end{tabular} & $20.33 \%$ & $1.08[0.92,1.27]$ \\
\hline Datiko 2009 ETH & $202 / 227$ & $73 / 87$ & - & $35.02 \%$ & $1.06[0.96,1.18]$ \\
\hline Shargie 2006 ETH & $125 / 155$ & $161 / 216$ & & $44.64 \%$ & $1.08[0.97,1.21]$ \\
\hline Total $(95 \% \mathrm{CI})$ & 457 & 392 & & $100 \%$ & $1.07[1,1.15]$ \\
\hline \multicolumn{6}{|c|}{ Heterogeneity: $\operatorname{Tau}^{2}=0 ; \mathrm{Chi}^{2}=0.08, \mathrm{df}=2(\mathrm{P}=0.96) ;\left.\right|^{2}=0 \%$} \\
\hline Test for overall effec & & & & & \\
\hline
\end{tabular}

Analysis 1.7. Comparison 1 Outreach tuberculosis screening versus no intervention, Outcome 7 Tuberculosis treatment failure.

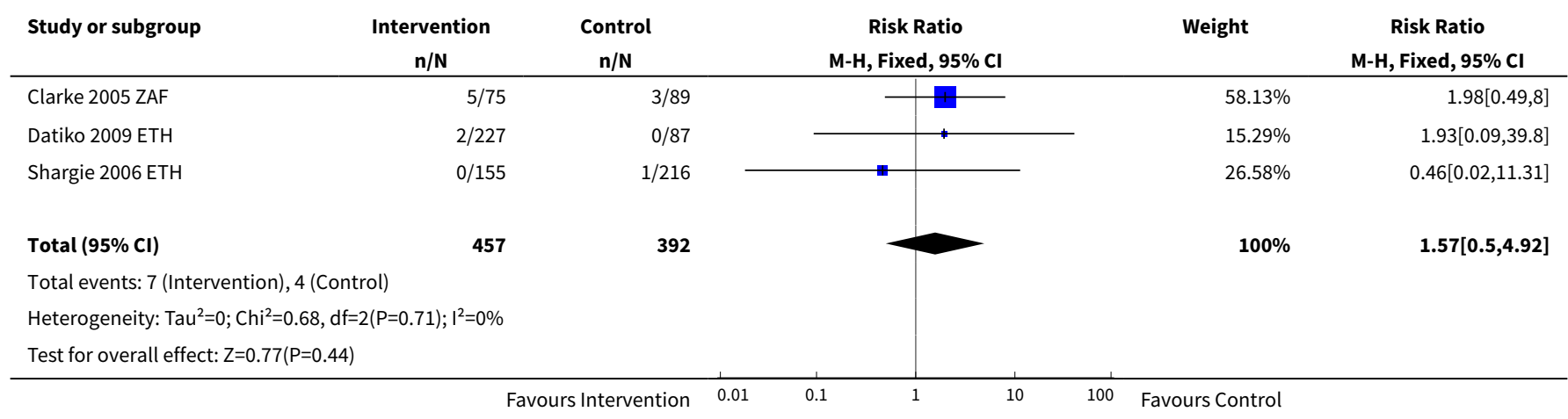

Analysis 1.8. Comparison 1 Outreach tuberculosis screening versus no intervention, Outcome 8 Tuberculosis mortality.

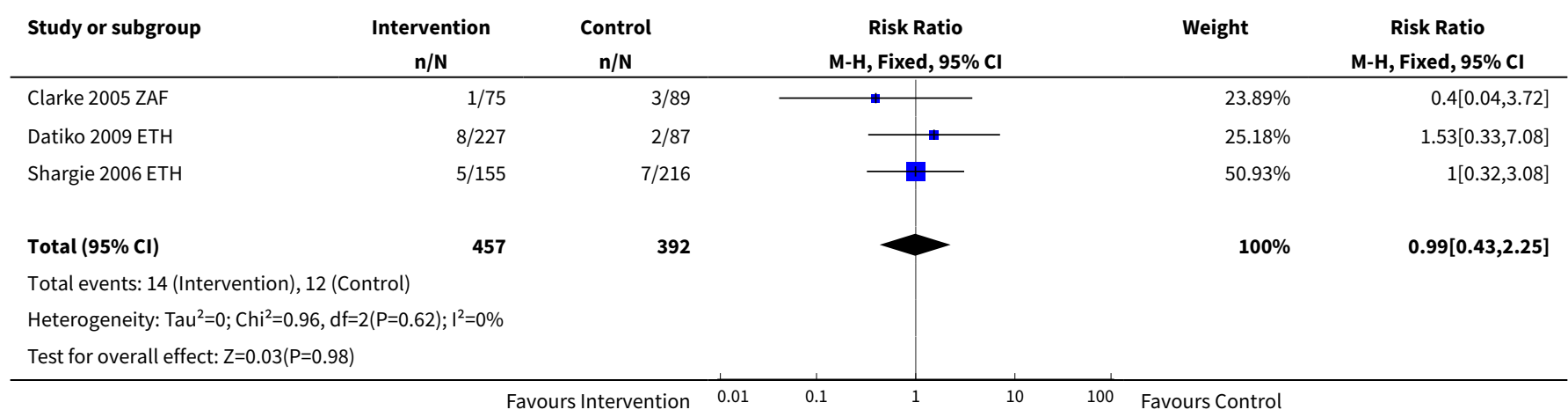


Analysis 1.9. Comparison 1 Outreach tuberculosis screening versus no intervention, Outcome 9 Long-term tuberculosis prevalence.

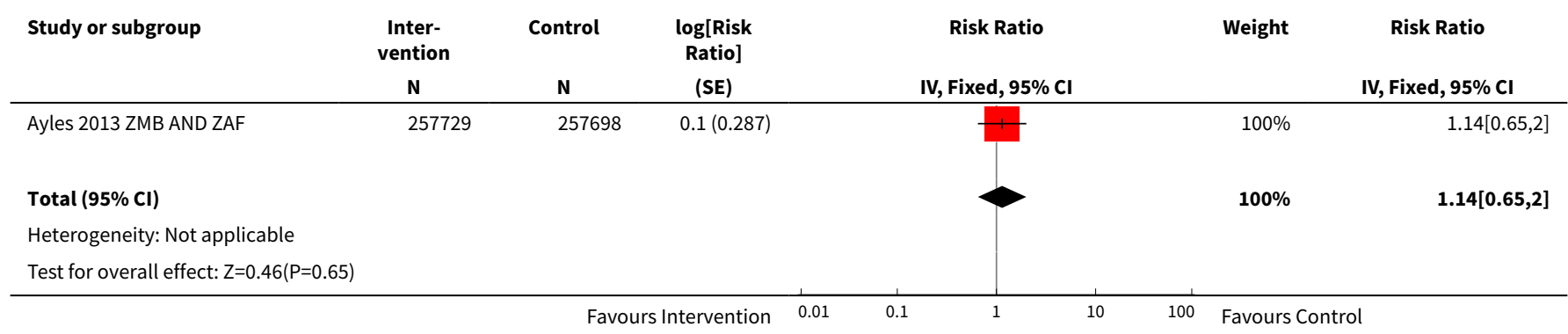

\section{Comparison 2. Health promotion activities compared to no intervention}

\begin{tabular}{lllll}
\hline Outcome or subgroup title & No. of studies & $\begin{array}{l}\text { No. of partici- } \\
\text { pants }\end{array}$ & Statistical method & Effect size \\
\hline 1 Long-term tuberculosis prevalence & 1 & & Risk Ratio (Fixed, 95\% Cl) & Totals not selected \\
\hline
\end{tabular}

Analysis 2.1. Comparison 2 Health promotion activities compared to no intervention, Outcome 1 Long-term tuberculosis prevalence.

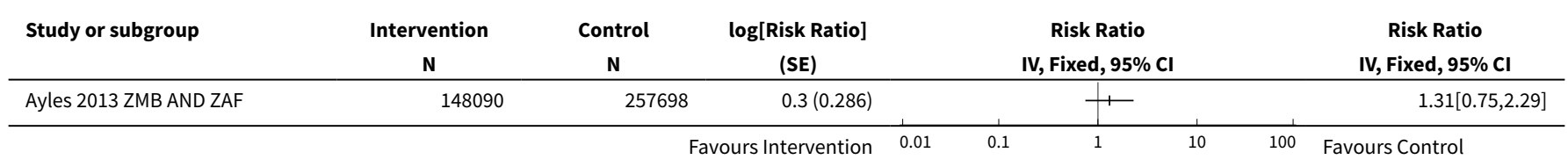

\section{Comparison 3. Training interventions compared to intervention}

\begin{tabular}{lllll}
\hline Outcome or subgroup title & No. of studies & $\begin{array}{l}\text { No. of partici- } \\
\text { pants }\end{array}$ & Statistical method & Effect size \\
\hline $\begin{array}{l}1 \text { Tuberculosis cases detected (microbio- } \\
\text { logically confirmed) }\end{array}$ & 1 & & $\begin{array}{l}\text { Risk Ratio (M-H, Random, } \\
95 \% \mathrm{Cl})\end{array}$ & $\begin{array}{l}\text { Totals not select- } \\
\text { ed }\end{array}$ \\
\hline
\end{tabular}

Analysis 3.1. Comparison 3 Training interventions compared to intervention, Outcome 1 Tuberculosis cases detected (microbiologically confirmed).

\begin{tabular}{|c|c|c|c|c|c|c|}
\hline Study or subgroup & $\begin{array}{c}\text { Intervention } \\
\mathbf{n} / \mathbf{N}\end{array}$ & $\begin{array}{c}\text { Control } \\
\mathrm{n} / \mathrm{N}\end{array}$ & & & $\begin{array}{l}\text { Ratio } \\
\text { om, } 95 \% \mathrm{Cl}\end{array}$ & $\begin{array}{c}\text { Risk Ratio } \\
\text { M-H, Random, } 95 \% \mathrm{CI}\end{array}$ \\
\hline Fairall $2005 \mathrm{ZAF}$ & $42 / 745$ & $25 / 744$ & & & - & $1.68[1.03,2.72]$ \\
\hline
\end{tabular}


Comparison 4. Outreach tuberculosis services versus health promotion

\begin{tabular}{lllll}
\hline Outcome or subgroup title & No. of studies & $\begin{array}{l}\text { No. of partici- } \\
\text { pants }\end{array}$ & Statistical method & Effect size \\
\hline $\begin{array}{l}1 \text { Tuberculosis cases detected (microbi- } \\
\text { ologically confirmed) }\end{array}$ & 1 & Risk Ratio (Fixed, 95\% Cl) & $\begin{array}{l}\text { Totals not select- } \\
\text { ed }\end{array}$ \\
\hline 1.1 Adjusted for cluster design & 1 & Risk Ratio (Fixed, 95\% Cl) & $0.0[0.0,0.0]$ \\
\hline
\end{tabular}

Analysis 4.1. Comparison 4 Outreach tuberculosis services versus health promotion, Outcome 1 Tuberculosis cases detected (microbiologically confirmed).

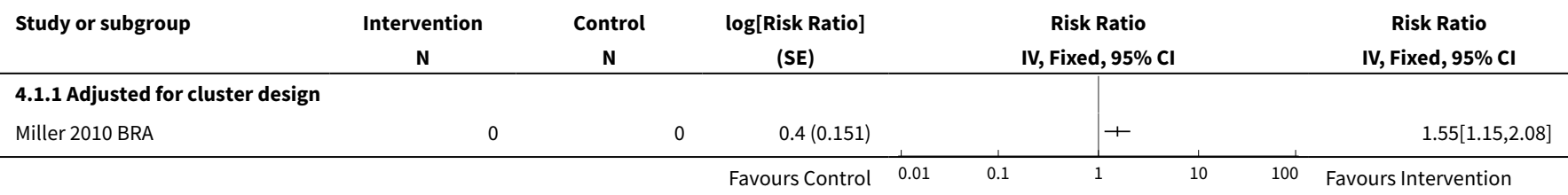

Comparison 5. Outreach clinic versus house-to-house screening

\begin{tabular}{lllll}
\hline Outcome or subgroup title & No. of studies & $\begin{array}{l}\text { No. of partici- } \\
\text { pants }\end{array}$ & Statistical method & Effect size \\
\hline $\begin{array}{l}\text { 1 Tuberculosis cases detected (microbi- } \\
\text { ologically confirmed) }\end{array}$ & 1 & & $\begin{array}{l}\text { Risk Ratio (Random, 95\% } \\
\text { Cl) }\end{array}$ & $\begin{array}{l}\text { Totals not select- } \\
\text { ed }\end{array}$ \\
\hline $\begin{array}{llll}1.1 \text { Adjusted for cluster design } \\
\text { Risk Ratio (Random, 95\% }\end{array}$ & $0.0[0.0,0.0]$ \\
\hline
\end{tabular}

Analysis 5.1. Comparison 5 Outreach clinic versus house-to-house screening, Outcome 1 Tuberculosis cases detected (microbiologically confirmed).

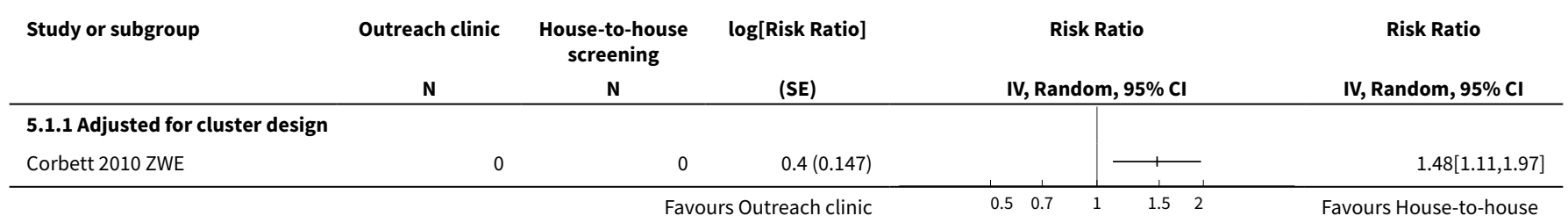

\section{Comparison 6. Active case-finding interventions versus no intervention}

\begin{tabular}{lllll}
\hline Outcome or subgroup title & No. of studies & $\begin{array}{l}\text { No. of partici- } \\
\text { pants }\end{array}$ & Statistical method & Effect size \\
\hline $\begin{array}{l}1 \text { Tuberculosis cases detected (micro- } \\
\text { biologically confirmed) }\end{array}$ & 5 & & $\begin{array}{l}\text { Risk Ratio (M-H, Random, } \\
95 \% \mathrm{Cl})\end{array}$ & Subtotals only
\end{tabular}

Interventions to increase tuberculosis case detection at primary healthcare or community-level services (Review) 


\begin{tabular}{|c|c|c|c|c|}
\hline Outcome or subgroup title & No. of studies & $\begin{array}{l}\text { No. of partici- } \\
\text { pants }\end{array}$ & Statistical method & Effect size \\
\hline $\begin{array}{l}2 \text { Tuberculosis cases detected: sub- } \\
\text { grouped by tuberculosis prevalence }\end{array}$ & 5 & 164532 & $\begin{array}{l}\text { Risk Ratio (M-H, Fixed, 95\% } \\
\mathrm{Cl})\end{array}$ & $1.24[1.01,1.53]$ \\
\hline 2.1 Prevalence < 5\% & 1 & 7125 & $\begin{array}{l}\text { Risk Ratio (M-H, Fixed, 95\% } \\
\mathrm{Cl})\end{array}$ & $0.85[0.60,1.19]$ \\
\hline 2.2 Prevalence $5 \%+$ & 4 & 157407 & $\begin{array}{l}\text { Risk Ratio (M-H, Fixed, 95\% } \\
\mathrm{Cl})\end{array}$ & $1.56[1.20,2.04]$ \\
\hline $\begin{array}{l}3 \text { Tuberculosis cases detected; sub- } \\
\text { grouped by intervention }\end{array}$ & 7 & & Risk Ratio (Random, 95\% Cl) & Subtotals only \\
\hline $\begin{array}{l}3.1 \text { House-to-house screening plus } \\
\text { health promotion }\end{array}$ & 3 & 305698 & Risk Ratio (Random, 95\% Cl) & $1.30[0.84,2.03]$ \\
\hline $\begin{array}{l}3.2 \text { Outreach tuberculosis diagnosis } \\
\text { clinics plus health promotion }\end{array}$ & 2 & 463323 & Risk Ratio (Random, 95\% Cl) & $1.43[1.11,1.84]$ \\
\hline 3.3 Health promotion activities alone & 1 & 405788 & Risk Ratio (Random, 95\% Cl) & $1.31[0.75,2.29]$ \\
\hline $\begin{array}{l}\text { 3.4 Health staff training in tuberculo- } \\
\text { sis diagnosis }\end{array}$ & 1 & 1999 & Risk Ratio (Random, 95\% Cl) & $1.68[1.03,2.73]$ \\
\hline $\begin{array}{l}4 \text { Long-term tuberculosis prevalence: } \\
\text { subgrouped by intervention }\end{array}$ & 1 & & Risk Ratio (Fixed, 95\% Cl) & $1.22[0.82,1.82]$ \\
\hline $\begin{array}{l}4.1 \text { Contact tracing plus health pro- } \\
\text { motion activities }\end{array}$ & 1 & & Risk Ratio (Fixed, 95\% Cl) & $1.14[0.65,2.00]$ \\
\hline 4.2 Health promotion activities alone & 1 & & Risk Ratio (Fixed, 95\% Cl) & $1.31[0.75,2.29]$ \\
\hline 5 Tuberculosis treatment success & 3 & 862 & $\begin{array}{l}\text { Risk Ratio (M-H, Random, } \\
95 \% \mathrm{Cl})\end{array}$ & $1.07[1.00,1.15]$ \\
\hline 6 Tuberculosis treatment default & 4 & 3034 & $\begin{array}{l}\text { Risk Ratio (M-H, Random, } \\
95 \% \mathrm{Cl})\end{array}$ & $0.62[0.47,0.83]$ \\
\hline 7 Tuberculosis treatment failure & 3 & 862 & $\begin{array}{l}\text { Risk Ratio (M-H, Random, } \\
95 \% \mathrm{Cl})\end{array}$ & $1.62[0.50,5.26]$ \\
\hline 8 Tuberculosis mortality & 3 & 862 & $\begin{array}{l}\text { Risk Ratio (M-H, Random, } \\
95 \% \mathrm{Cl})\end{array}$ & $0.99[0.43,2.31]$ \\
\hline 9 People with tuberculosis detected & 3 & 134339 & $\begin{array}{l}\text { Risk Ratio (M-H, Fixed, 95\% } \\
\mathrm{Cl})\end{array}$ & $1.13[0.89,1.44]$ \\
\hline 9.1 Prevalence < 5\% & 1 & 7125 & $\begin{array}{l}\text { Risk Ratio (M-H, Fixed, 95\% } \\
\mathrm{Cl})\end{array}$ & $0.85[0.60,1.19]$ \\
\hline 9.2 Prevalence $5 \%+$ & 2 & 127214 & $\begin{array}{l}\text { Risk Ratio (M-H, Fixed, 95\% } \\
\mathrm{Cl})\end{array}$ & $1.53[1.07,2.19]$ \\
\hline
\end{tabular}


Analysis 6.1. Comparison 6 Active case-finding interventions versus no intervention, Outcome 1 Tuberculosis cases detected (microbiologically confirmed).

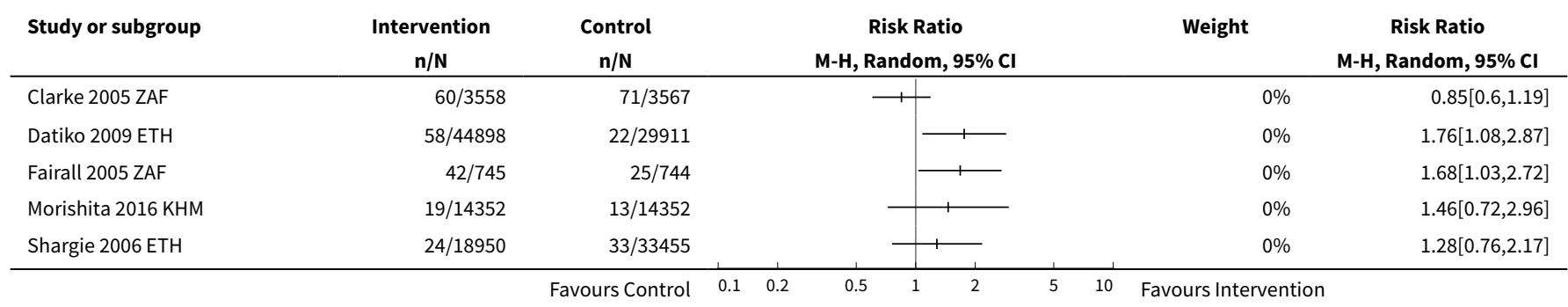

Analysis 6.2. Comparison 6 Active case-finding interventions versus no intervention, Outcome 2 Tuberculosis cases detected: subgrouped by tuberculosis prevalence.

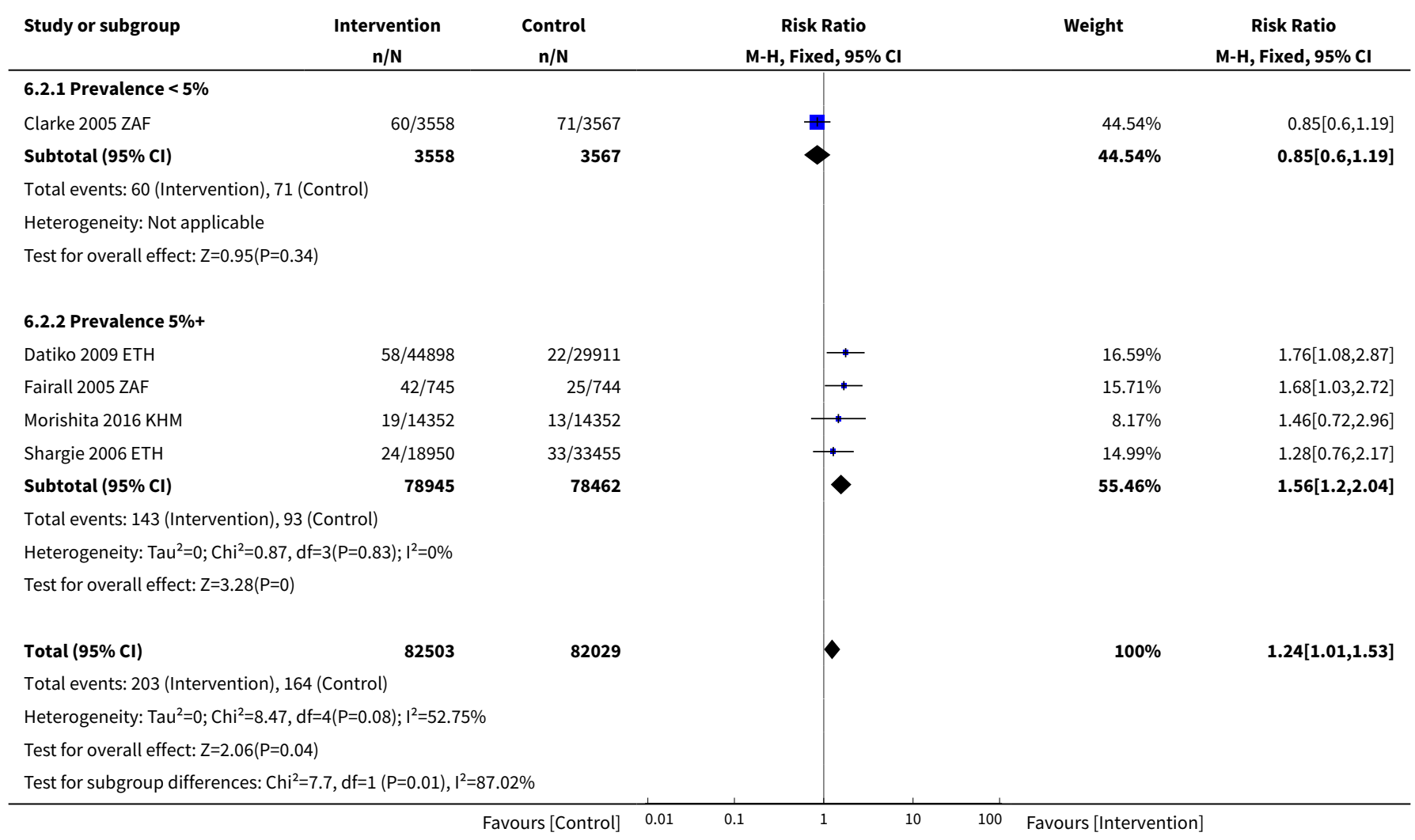

Analysis 6.3. Comparison 6 Active case-finding interventions versus no intervention, Outcome 3 Tuberculosis cases detected; subgrouped by intervention.

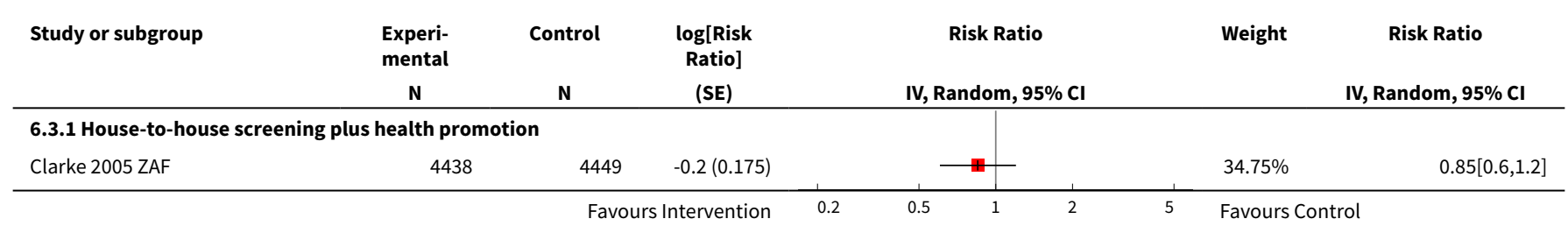




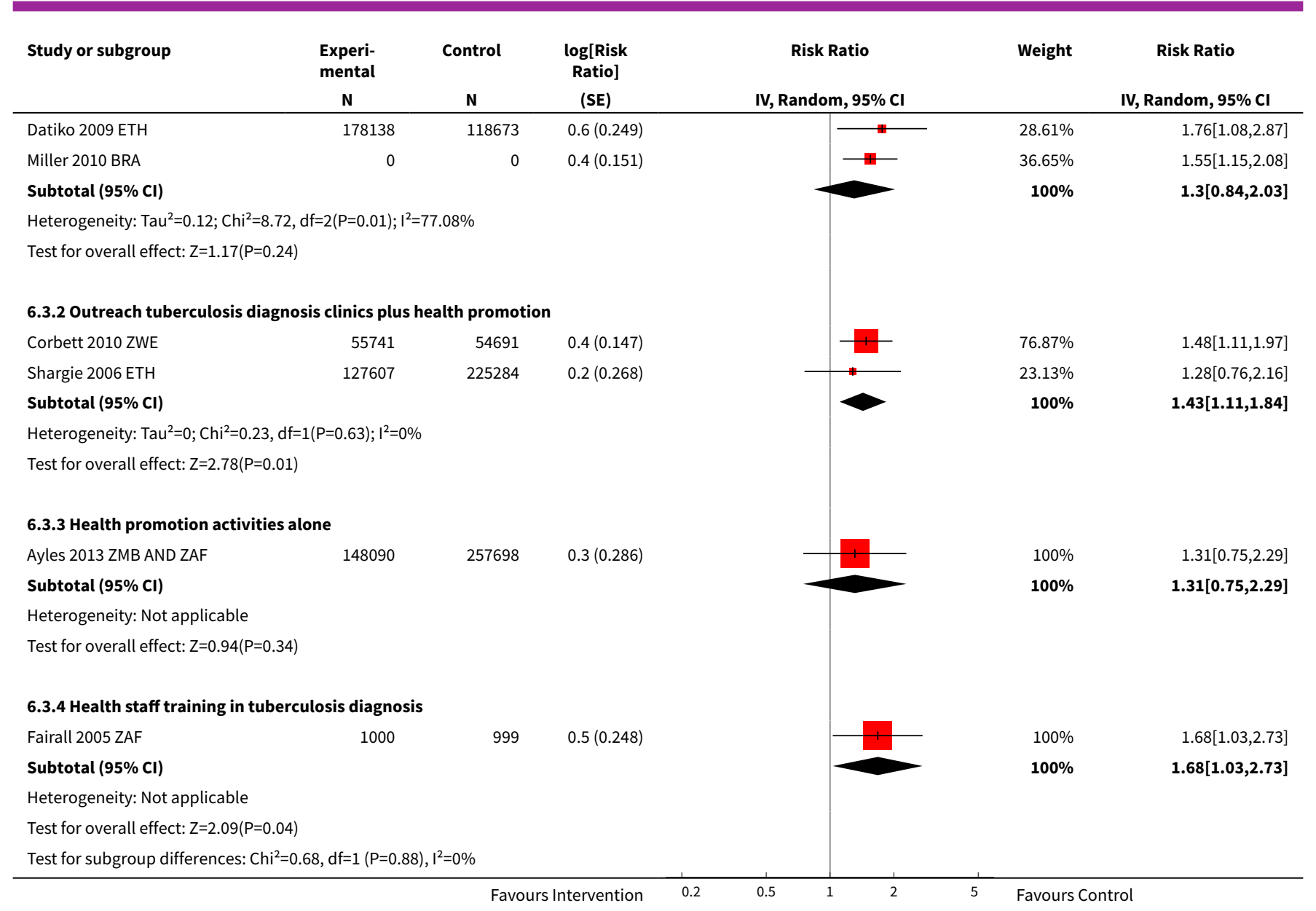

\section{Analysis 6.4. Comparison 6 Active case-finding interventions versus no intervention, Outcome 4 Long-term tuberculosis prevalence: subgrouped by intervention.}

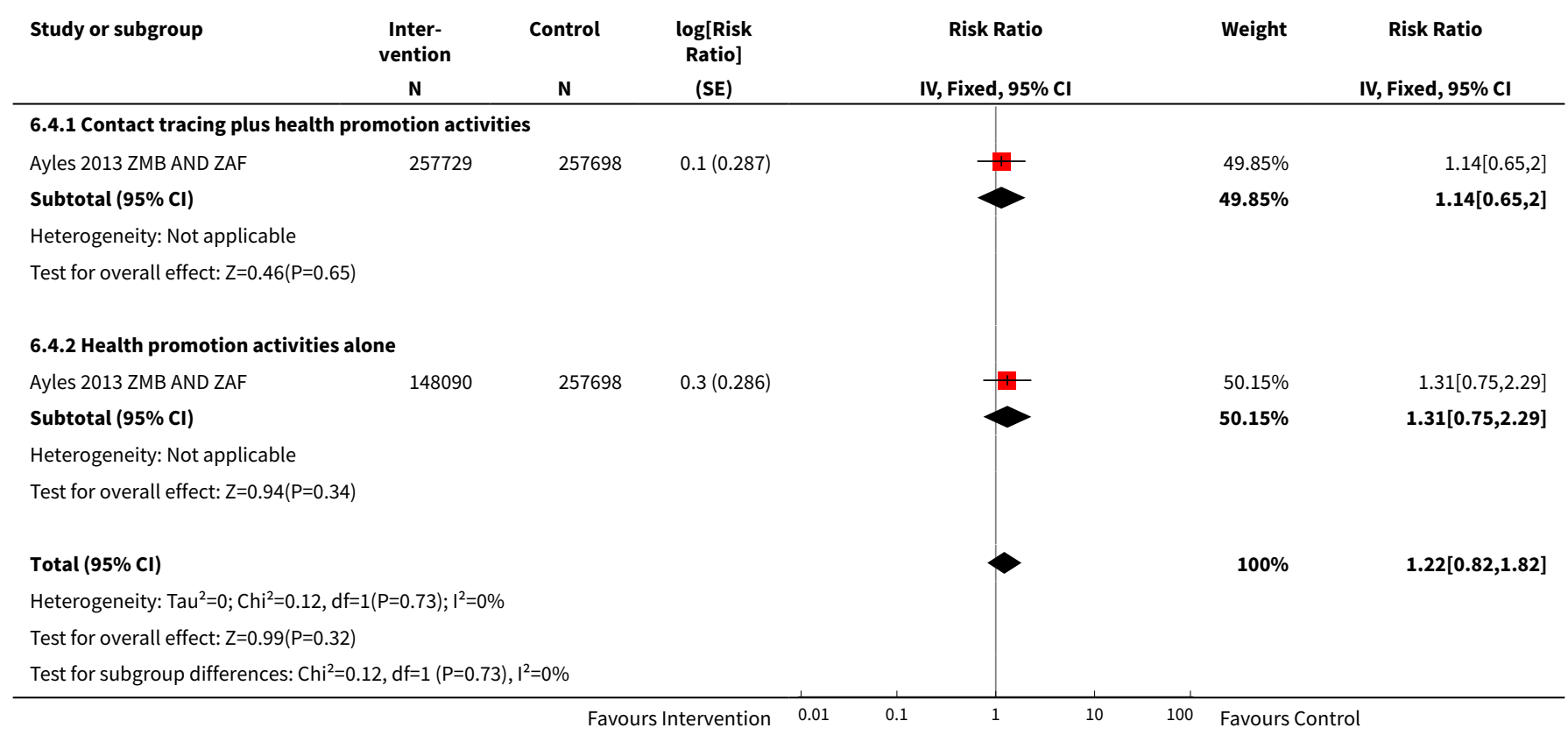


Analysis 6.5. Comparison 6 Active case-finding interventions versus no intervention, Outcome 5 Tuberculosis treatment success.

\begin{tabular}{|c|c|c|c|c|c|}
\hline Study or subgroup & $\begin{array}{c}\text { Intervention } \\
\mathrm{n} / \mathrm{N}\end{array}$ & $\begin{array}{c}\text { Control } \\
n / N\end{array}$ & $\begin{array}{c}\text { Risk Ratio } \\
\text { M-H, Random, 95\% Cl }\end{array}$ & Weight & $\begin{array}{c}\text { Risk Ratio } \\
\text { M-H, Random, } 95 \% \text { Cl }\end{array}$ \\
\hline Clarke $2005 \mathrm{ZAF}$ & $61 / 75$ & $67 / 89$ & - & $17.47 \%$ & $1.08[0.92,1.27]$ \\
\hline Datiko 2009 ETH & $205 / 230$ & $74 / 88$ & -1 & $43.99 \%$ & $1.06[0.96,1.17]$ \\
\hline Shargie 2006 ETH & $128 / 159$ & $165 / 221$ & & $38.54 \%$ & $1.08[0.97,1.2]$ \\
\hline Total $(95 \% \mathrm{Cl})$ & 464 & 398 & & $100 \%$ & $1.07[1,1.15]$ \\
\hline \multicolumn{6}{|c|}{ Heterogeneity: $\mathrm{Tau}^{2}=0 ; \mathrm{Chi}^{2}=0.07, \mathrm{df}=2(\mathrm{P}=0.97) ; \mathrm{I}^{2}=0 \%$} \\
\hline Test for overall effec & & & & & \\
\hline
\end{tabular}

Analysis 6.6. Comparison 6 Active case-finding interventions versus no intervention, Outcome 6 Tuberculosis treatment default.

\begin{tabular}{|c|c|c|c|c|c|}
\hline Study or subgroup & $\begin{array}{c}\text { Intervention } \\
\mathrm{n} / \mathrm{N} \\
\end{array}$ & $\begin{array}{c}\text { Control } \\
n / N\end{array}$ & $\begin{array}{c}\text { Risk Ratio } \\
\text { M-H, Random, } 95 \% \mathrm{Cl}\end{array}$ & Weight & $\begin{array}{c}\text { Risk Ratio } \\
\text { M-H, Random, 95\% Cl }\end{array}$ \\
\hline Clarke 2005 ZAF & $6 / 75$ & $14 / 89$ & $\longrightarrow$ & $9.86 \%$ & $0.51[0.21,1.26]$ \\
\hline Datiko 2009 ETH & $15 / 230$ & $9 / 88$ & $\longrightarrow$ & $12.99 \%$ & $0.64[0.29,1.4]$ \\
\hline Morishita 2016 KHM & $46 / 1725$ & $23 / 447$ & - & $33.73 \%$ & $0.52[0.32,0.85]$ \\
\hline Shargie 2006 ETH & $26 / 159$ & $48 / 221$ & $\rightarrow$ & $43.42 \%$ & $0.75[0.49,1.16]$ \\
\hline \multicolumn{6}{|c|}{ Total events: 93 (Intervention), 94 (Control) } \\
\hline \multicolumn{6}{|c|}{ Heterogeneity: $\operatorname{Tau}^{2}=0 ; \mathrm{Chi}^{2}=1.48, \mathrm{df}=3(\mathrm{P}=0.69) ; \mathrm{I}^{2}=0 \%$} \\
\hline \multicolumn{6}{|c|}{ Test for overall effect: $Z=3.24(P=0)$} \\
\hline
\end{tabular}

Analysis 6.7. Comparison 6 Active case-finding interventions versus no intervention, Outcome 7 Tuberculosis treatment failure.

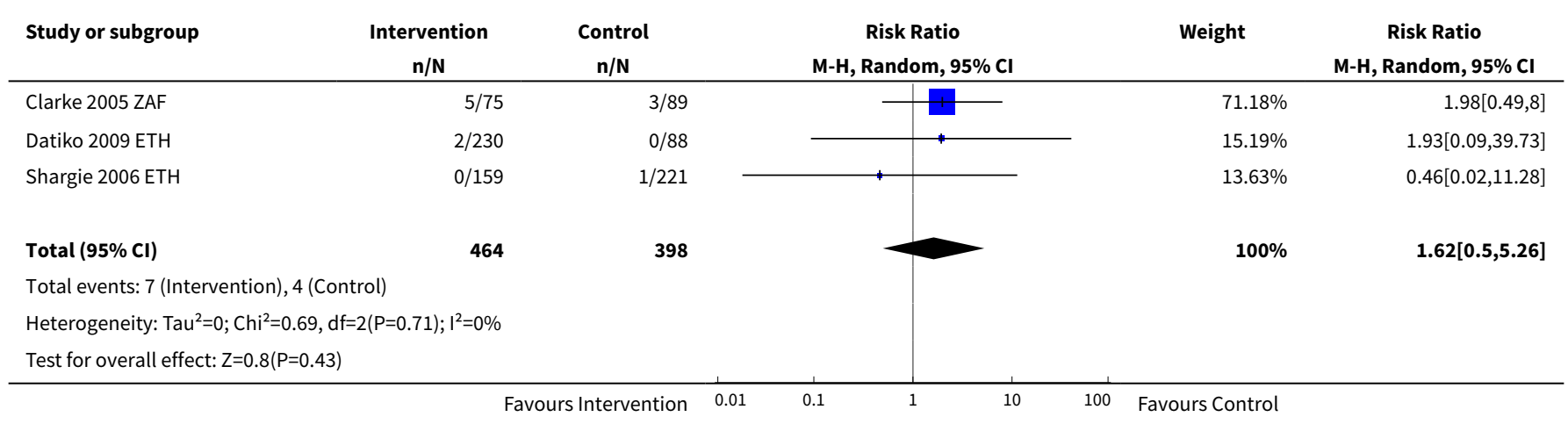


Analysis 6.8. Comparison 6 Active case-finding interventions versus no intervention, Outcome 8 Tuberculosis mortality.

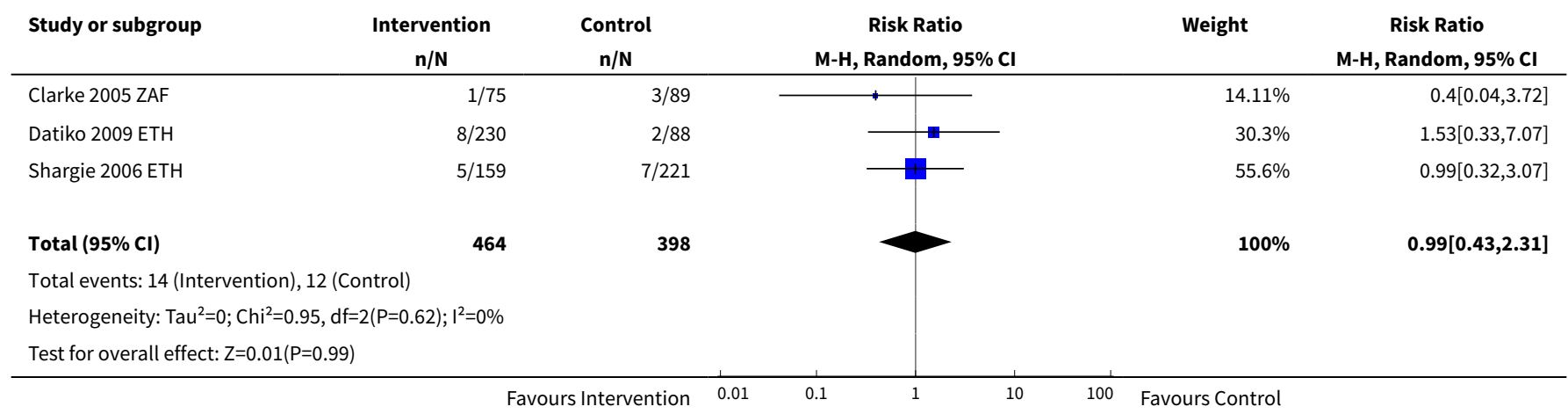

Analysis 6.9. Comparison 6 Active case-finding interventions versus no intervention, Outcome 9 People with tuberculosis detected.

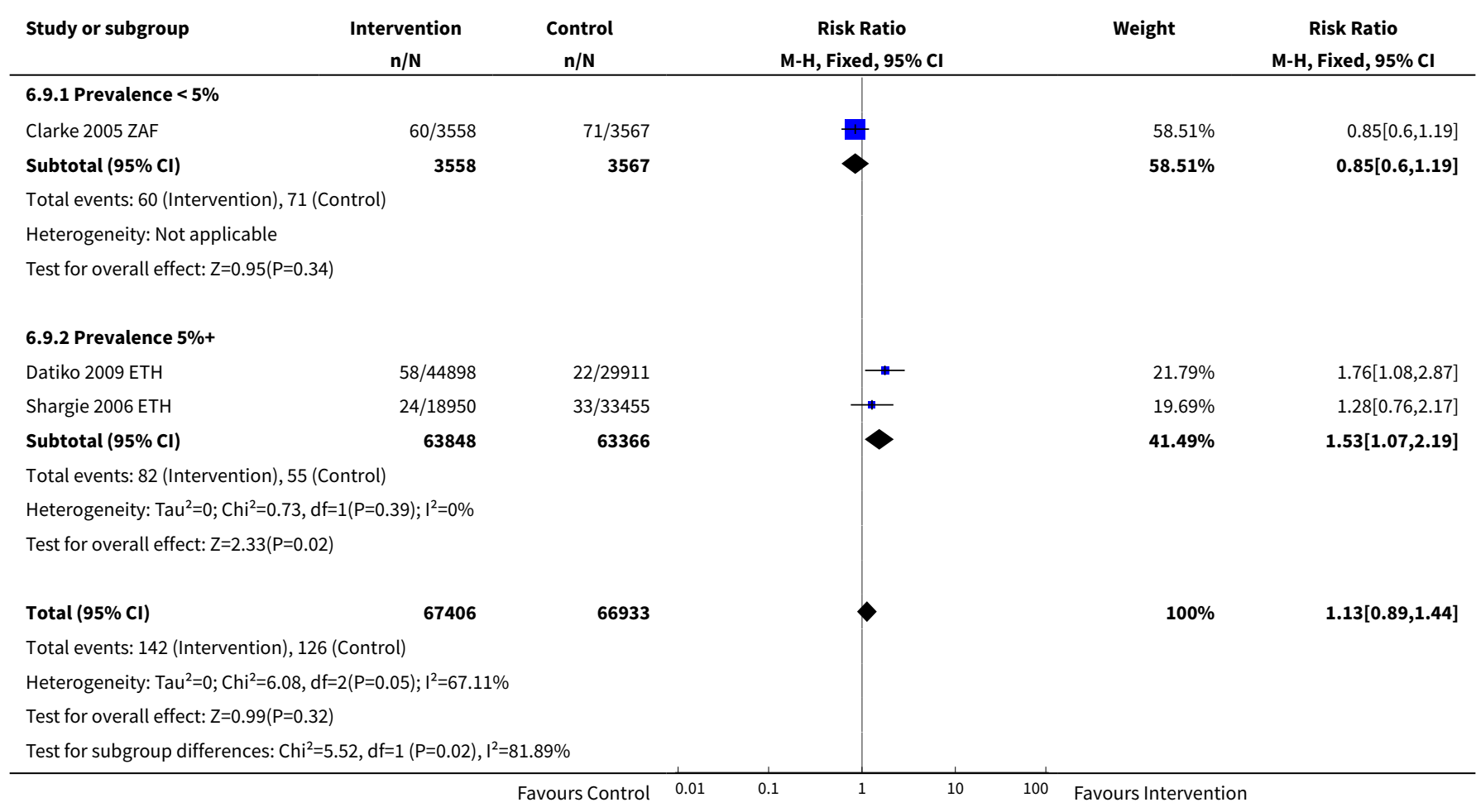

\section{Comparison 7. Outreach tuberculosis services versus no intervention (sensitivity analyses)}

\begin{tabular}{lllll}
\hline Outcome or subgroup title & No. of studies & $\begin{array}{l}\text { No. of partici- } \\
\text { pants }\end{array}$ & Statistical method & Effect size \\
\hline $\begin{array}{l}1 \text { Tuberculosis cases detected (mi- } \\
\text { crobiologically confirmed) }\end{array}$ & 4 & 163043 & $\begin{array}{l}\text { Risk Ratio (M-H, Random, 95\% } \\
\mathrm{Cl})\end{array}$ & $1.24[0.86,1.79]$ \\
\hline
\end{tabular}




\begin{tabular}{|c|c|c|c|c|}
\hline Outcome or subgroup title & No. of studies & $\begin{array}{l}\text { No. of partici- } \\
\text { pants }\end{array}$ & Statistical method & Effect size \\
\hline $\begin{array}{l}2 \text { Tuberculosis cases detected: } \\
\text { subgrouped by tuberculosis preva- } \\
\text { lence }\end{array}$ & 4 & 163043 & Risk Ratio (M-H, Fixed, 95\% Cl) & $1.16[0.92,1.46]$ \\
\hline 2.1 Prevalence $<5 \%$ & 1 & 7125 & Risk Ratio (M-H, Fixed, 95\% Cl) & $0.85[0.60,1.19]$ \\
\hline 2.2 Prevalence $5 \%+$ & 3 & 155918 & Risk Ratio (M-H, Fixed, 95\% Cl) & $1.52[1.10,2.09]$ \\
\hline $\begin{array}{l}3 \text { Tuberculosis cases detected; } \\
\text { subgrouped by intervention }\end{array}$ & 4 & 163043 & $\begin{array}{l}\text { Risk Ratio (M-H, Random, 95\% } \\
\mathrm{CI})\end{array}$ & $1.24[0.86,1.79]$ \\
\hline $\begin{array}{l}3.1 \text { Outreach clinics plus health } \\
\text { promotion }\end{array}$ & 1 & 52405 & $\begin{array}{l}\text { Risk Ratio (M-H, Random, 95\% } \\
\mathrm{Cl} \text { ) }\end{array}$ & $1.28[0.76,2.17]$ \\
\hline $\begin{array}{l}3.2 \text { House-to-house screening plus } \\
\text { health promotion }\end{array}$ & 3 & 110638 & $\begin{array}{l}\text { Risk Ratio (M-H, Random, 95\% } \\
\mathrm{Cl} \text { ) }\end{array}$ & $1.25[0.75,2.08]$ \\
\hline $\begin{array}{l}4 \text { Tuberculosis cases detected (all } \\
\text { forms) }\end{array}$ & 1 & 28704 & $\begin{array}{l}\text { Risk Ratio (M-H, Random, 95\% } \\
\mathrm{Cl})\end{array}$ & $1.28[0.83,1.98]$ \\
\hline 5 Tuberculosis treatment default & 3 & & Risk Ratio (M-H, Fixed, 95\% Cl) & Subtotals only \\
\hline 5.1 Raw data & 3 & 862 & Risk Ratio (M-H, Fixed, 95\% Cl) & $0.68[0.48,0.97]$ \\
\hline 5.2 Adjusted with ICC $=0.001$ & 3 & 849 & Risk Ratio (M-H, Fixed, 95\% Cl) & $0.67[0.47,0.96]$ \\
\hline 5.3 Adjusted ICC $=0.00052$ (Datiko) & 3 & 855 & Risk Ratio (M-H, Fixed, 95\% Cl) & $0.69[0.49,0.98]$ \\
\hline 6 Tuberculosis treatment success & 3 & & Risk Ratio (M-H, Fixed, 95\% Cl) & Subtotals only \\
\hline 6.1 Raw data & 3 & 862 & Risk Ratio (M-H, Fixed, 95\% Cl) & $1.07[1.00,1.15]$ \\
\hline 6.2 Cluster adjusted: ICC $=0.001$ & 3 & 849 & Risk Ratio (M-H, Fixed, 95\% Cl) & $1.07[1.00,1.15]$ \\
\hline 7 Tuberculosis treatment failure & 3 & & $\begin{array}{l}\text { Risk Ratio (M-H, Random, 95\% } \\
\mathrm{Cl})\end{array}$ & Subtotals only \\
\hline 7.1 Raw data & 3 & 862 & $\begin{array}{l}\text { Risk Ratio (M-H, Random, 95\% } \\
\mathrm{Cl})\end{array}$ & $1.62[0.50,5.26]$ \\
\hline 7.2 Cluster adjusted: ICC $=0.001$ & 3 & 849 & $\begin{array}{l}\text { Risk Ratio (M-H, Random, 95\% } \\
\mathrm{CI})\end{array}$ & $1.62[0.50,5.26]$ \\
\hline 8 Tuberculosis mortality & 3 & & Risk Ratio (M-H, Fixed, 95\% Cl) & Subtotals only \\
\hline 8.1 Raw data & 3 & 862 & Risk Ratio (M-H, Fixed, 95\% Cl) & $0.99[0.43,2.25]$ \\
\hline 8.2 Cluster adjusted: ICC $=0.001$ & 3 & 849 & Risk Ratio (M-H, Fixed, 95\% Cl) & $0.99[0.43,2.25]$ \\
\hline $\begin{array}{l}9 \text { Long-term tuberculosis preva- } \\
\text { lence }\end{array}$ & 1 & & Risk Ratio (Fixed, 95\% Cl) & $1.14[0.65,2.00]$ \\
\hline
\end{tabular}


Analysis 7.1. Comparison 7 Outreach tuberculosis services versus no intervention (sensitivity analyses), Outcome 1 Tuberculosis cases detected (microbiologically confirmed).

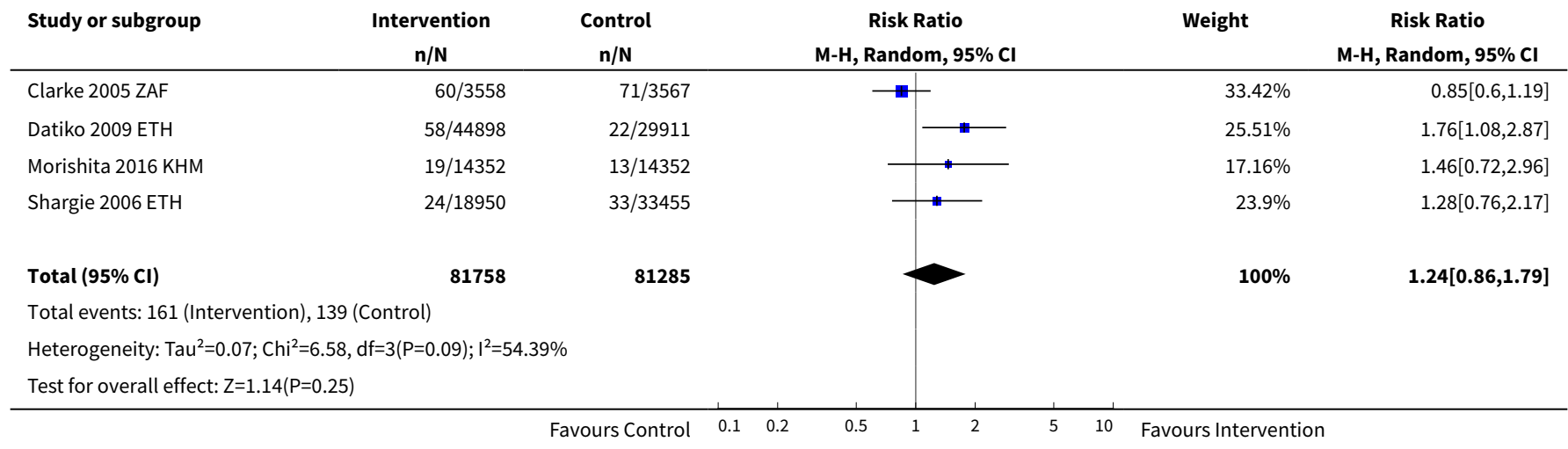

Analysis 7.2. Comparison 7 Outreach tuberculosis services versus no intervention (sensitivity analyses), Outcome 2 Tuberculosis cases detected: subgrouped by tuberculosis prevalence.

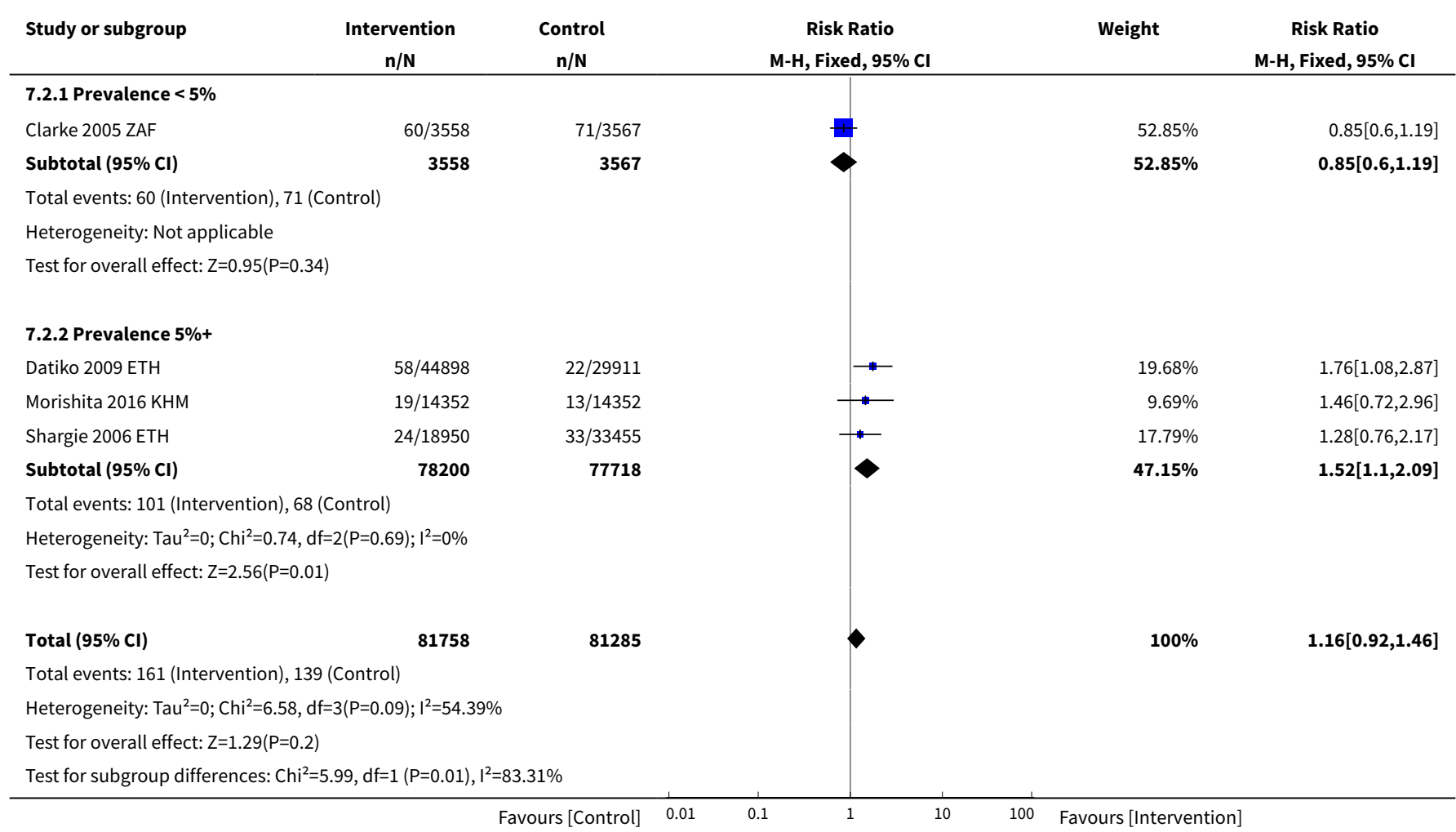


Analysis 7.3. Comparison 7 Outreach tuberculosis services versus no intervention (sensitivity analyses), Outcome 3 Tuberculosis cases detected; subgrouped by intervention.

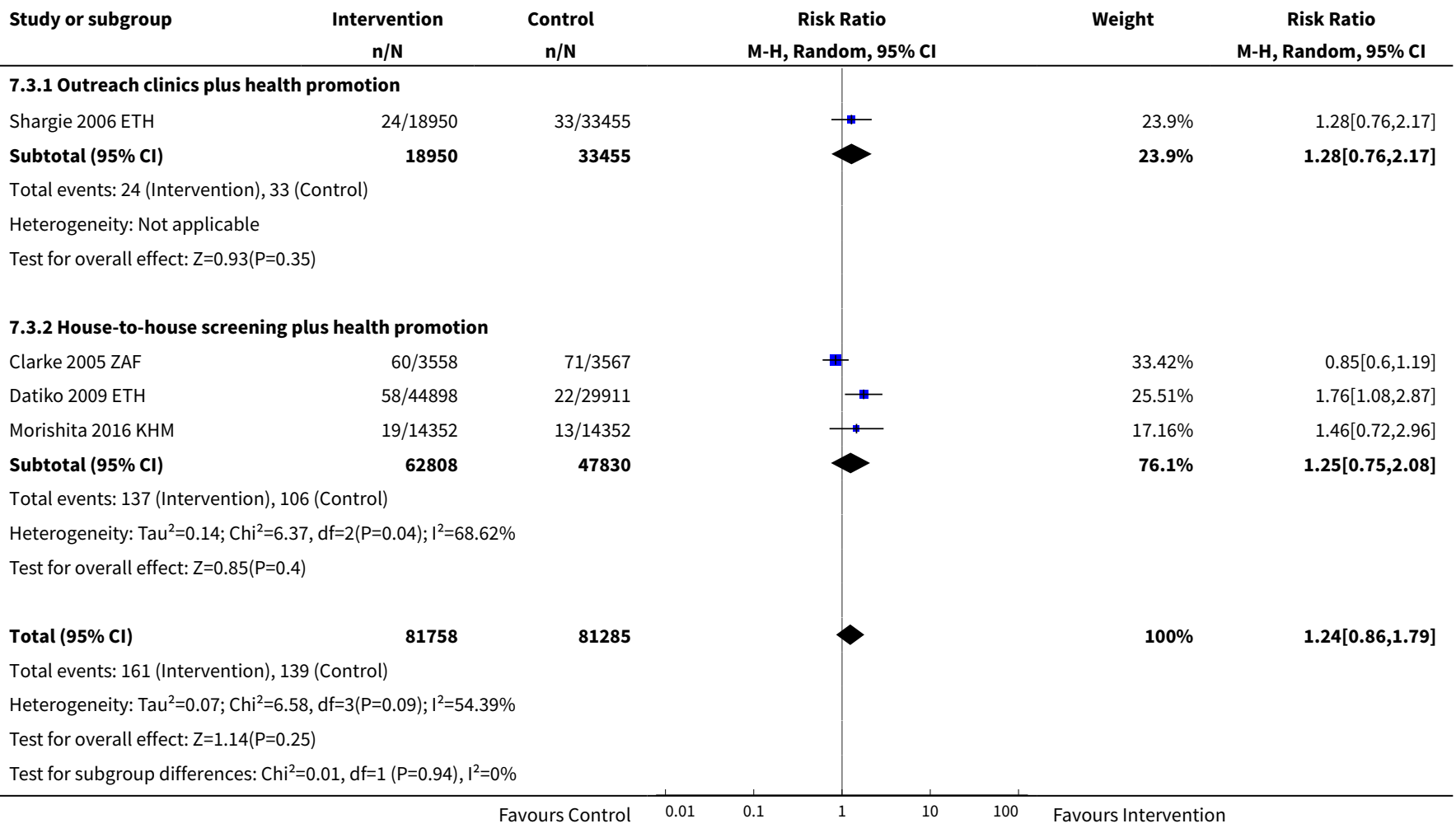

Analysis 7.4. Comparison 7 Outreach tuberculosis services versus no intervention (sensitivity analyses), Outcome 4 Tuberculosis cases detected (all forms).

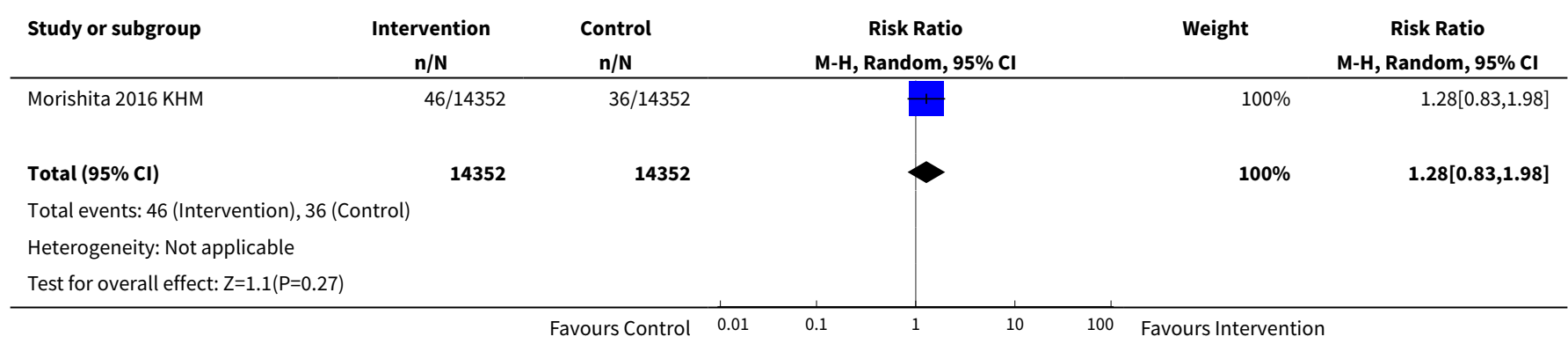

Analysis 7.5. Comparison 7 Outreach tuberculosis services versus no intervention (sensitivity analyses), Outcome 5 Tuberculosis treatment default.

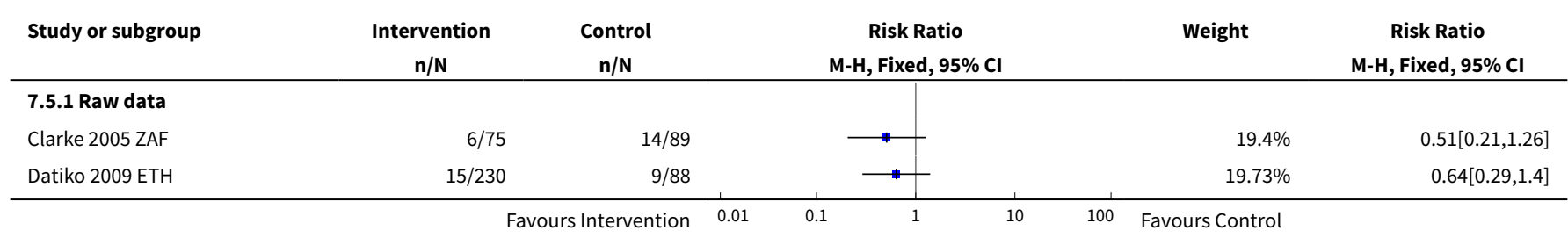




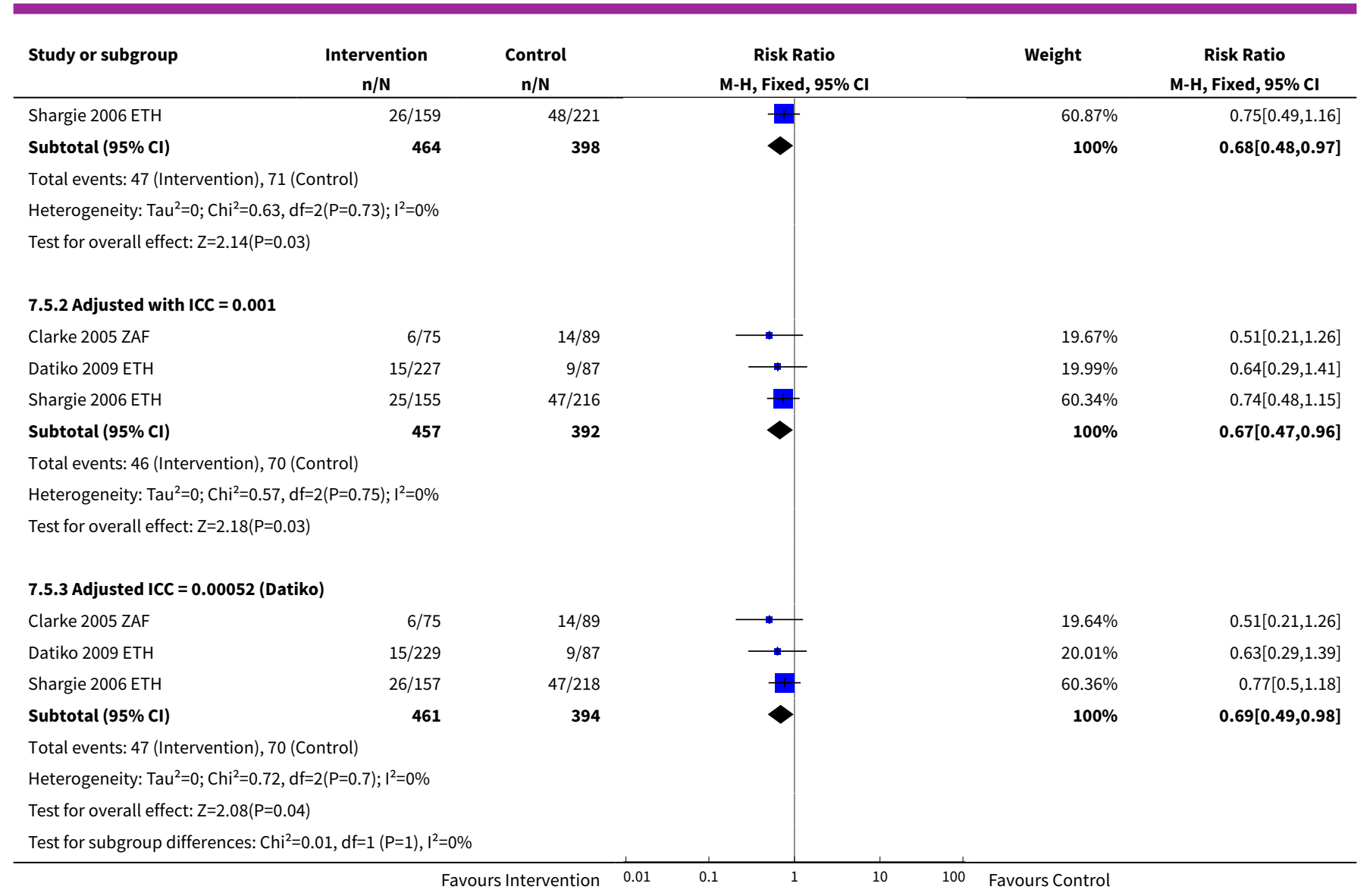

Analysis 7.6. Comparison 7 Outreach tuberculosis services versus no intervention (sensitivity analyses), Outcome 6 Tuberculosis treatment success.

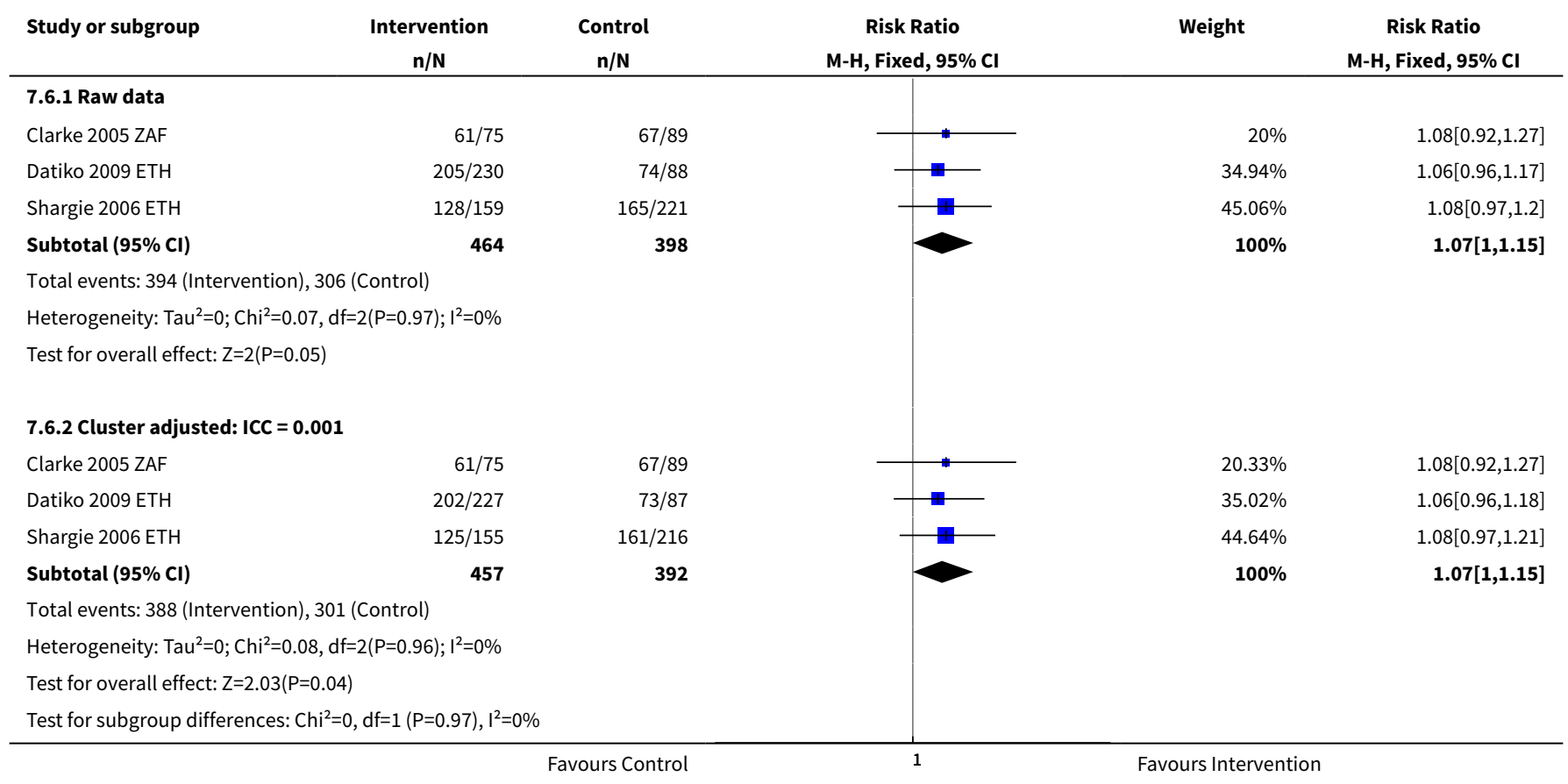


Analysis 7.7. Comparison 7 Outreach tuberculosis services versus no intervention (sensitivity analyses), Outcome 7 Tuberculosis treatment failure.

\begin{tabular}{|c|c|c|c|c|c|}
\hline Study or subgroup & $\begin{array}{c}\text { Intervention } \\
\mathbf{n} / \mathbf{N}\end{array}$ & $\begin{array}{c}\text { Control } \\
n / N\end{array}$ & $\begin{array}{c}\text { Risk Ratio } \\
\text { M-H, Random, } 95 \% \text { CI }\end{array}$ & Weight & $\begin{array}{c}\text { Risk Ratio } \\
\text { M-H, Random, 95\% Cl }\end{array}$ \\
\hline \multicolumn{6}{|l|}{ 7.7.1 Raw data } \\
\hline Clarke $2005 \mathrm{ZAF}$ & $5 / 75$ & $3 / 89$ & 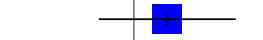 & $71.18 \%$ & $1.98[0.49,8]$ \\
\hline Datiko 2009 ETH & $2 / 230$ & $0 / 88$ & & $15.19 \%$ & $1.93[0.09,39.73]$ \\
\hline Shargie 2006 ETH & $0 / 159$ & $1 / 221$ & . & $13.63 \%$ & $0.46[0.02,11.28]$ \\
\hline Subtotal $(95 \% \mathrm{Cl})$ & 464 & 398 & & $100 \%$ & $1.62[0.5,5.26]$ \\
\hline \multicolumn{6}{|c|}{ Heterogeneity: $\operatorname{Tau}^{2}=0 ; \mathrm{Chi}^{2}=0.69, \mathrm{df}=2(\mathrm{P}=0.71) ; \mathrm{I}^{2}=0 \%$} \\
\hline \multicolumn{6}{|c|}{ Test for overall effect: $Z=0.8(P=0.43)$} \\
\hline \multicolumn{6}{|c|}{ 7.7.2 Cluster adjusted: ICC $=0.001$} \\
\hline Clarke $2005 \mathrm{ZAF}$ & $5 / 75$ & $3 / 89$ & & $71.18 \%$ & $1.98[0.49,8]$ \\
\hline Datiko 2009 ETH & $2 / 227$ & $0 / 87$ & & $15.19 \%$ & $1.93[0.09,39.8]$ \\
\hline Subtotal $(95 \% \mathrm{Cl})$ & 457 & 392 & & $100 \%$ & $1.62[0.5,5.26]$ \\
\hline \multicolumn{6}{|c|}{ Total events: 7 (Intervention), 4 (Control) } \\
\hline \multicolumn{6}{|c|}{ Heterogeneity: $\operatorname{Tau}^{2}=0 ; \mathrm{Chi}^{2}=0.68, \mathrm{df}=2(\mathrm{P}=0.71) ; \mathrm{I}^{2}=0 \%$} \\
\hline \multicolumn{6}{|c|}{ Test for overall effect: $Z=0.8(P=0.42)$} \\
\hline Test for subgroup dif & $\mathrm{df}=1(\mathrm{P}=1), \mathrm{I}^{2}=0 \%$ & & & & \\
\hline
\end{tabular}

Analysis 7.8. Comparison 7 Outreach tuberculosis services versus no intervention (sensitivity analyses), Outcome 8 Tuberculosis mortality.

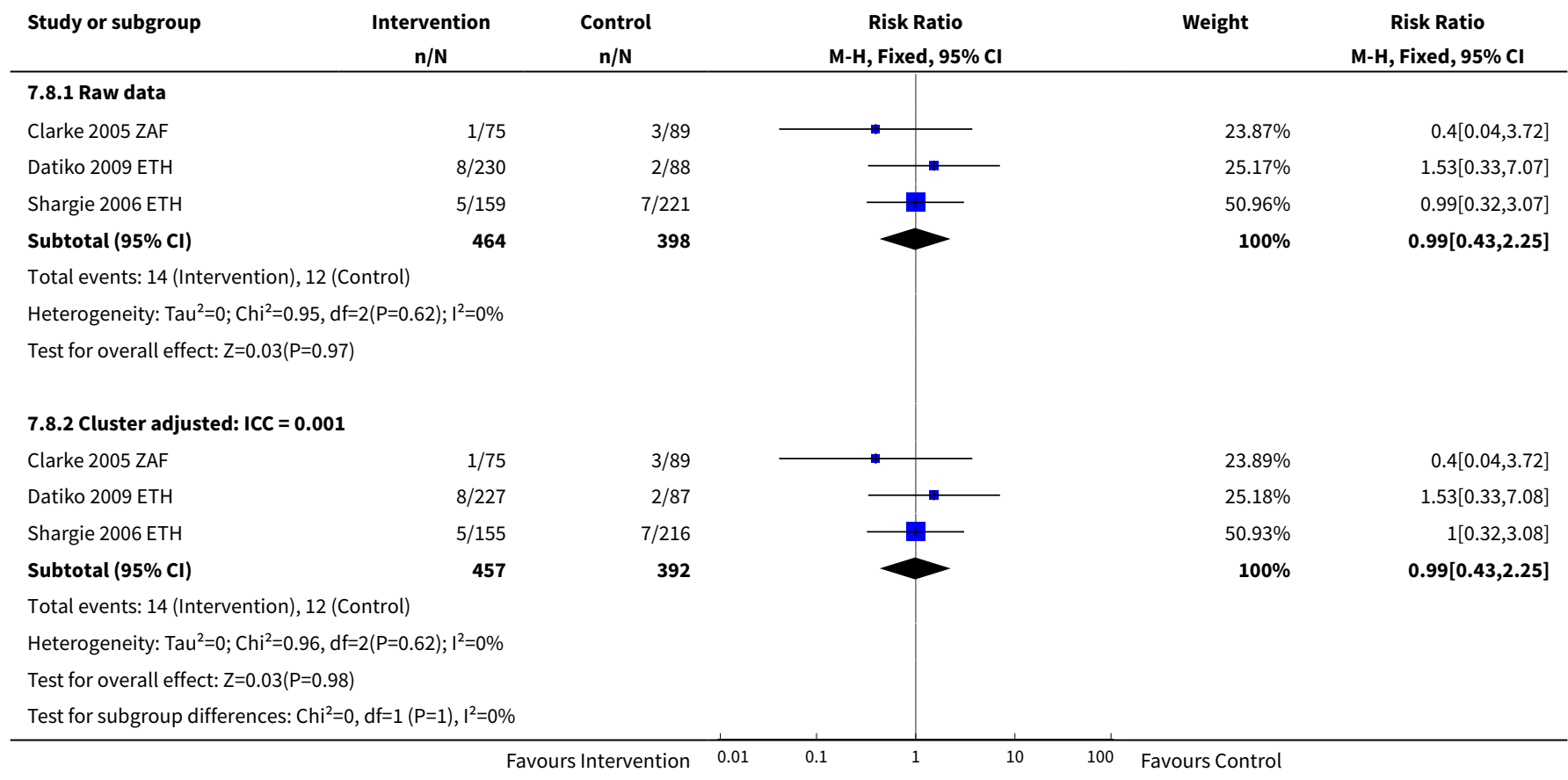


Analysis 7.9. Comparison 7 Outreach tuberculosis services versus no intervention

(sensitivity analyses), Outcome 9 Long-term tuberculosis prevalence.

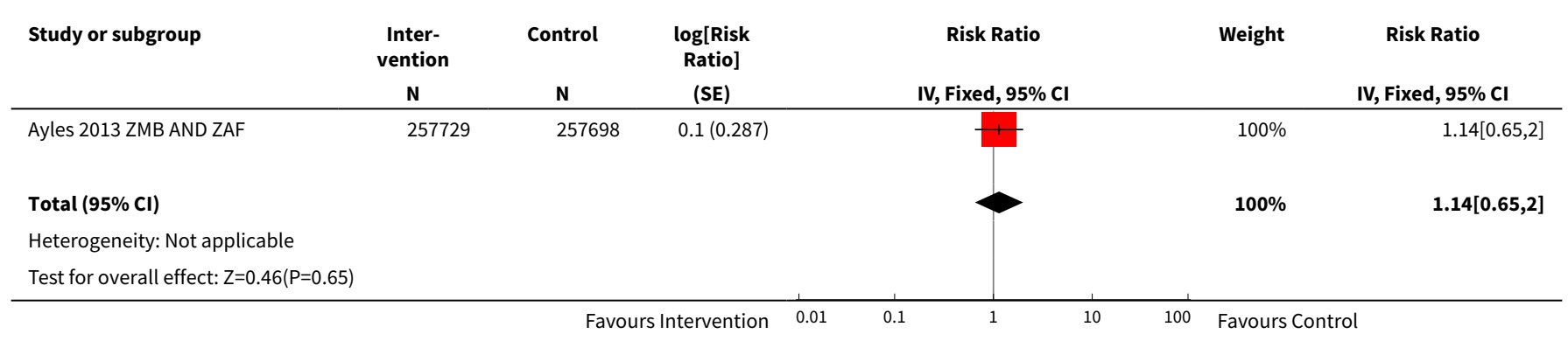




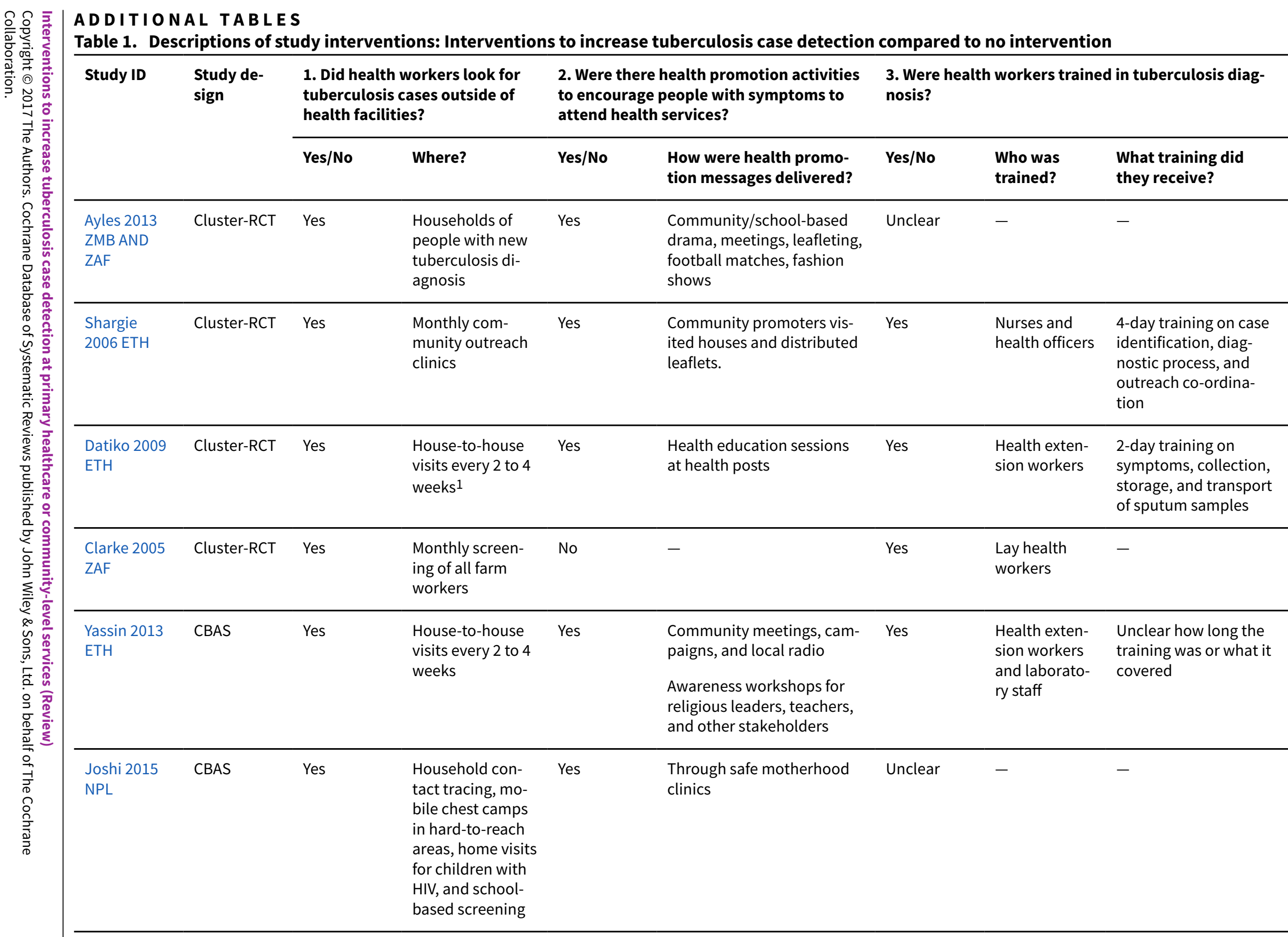




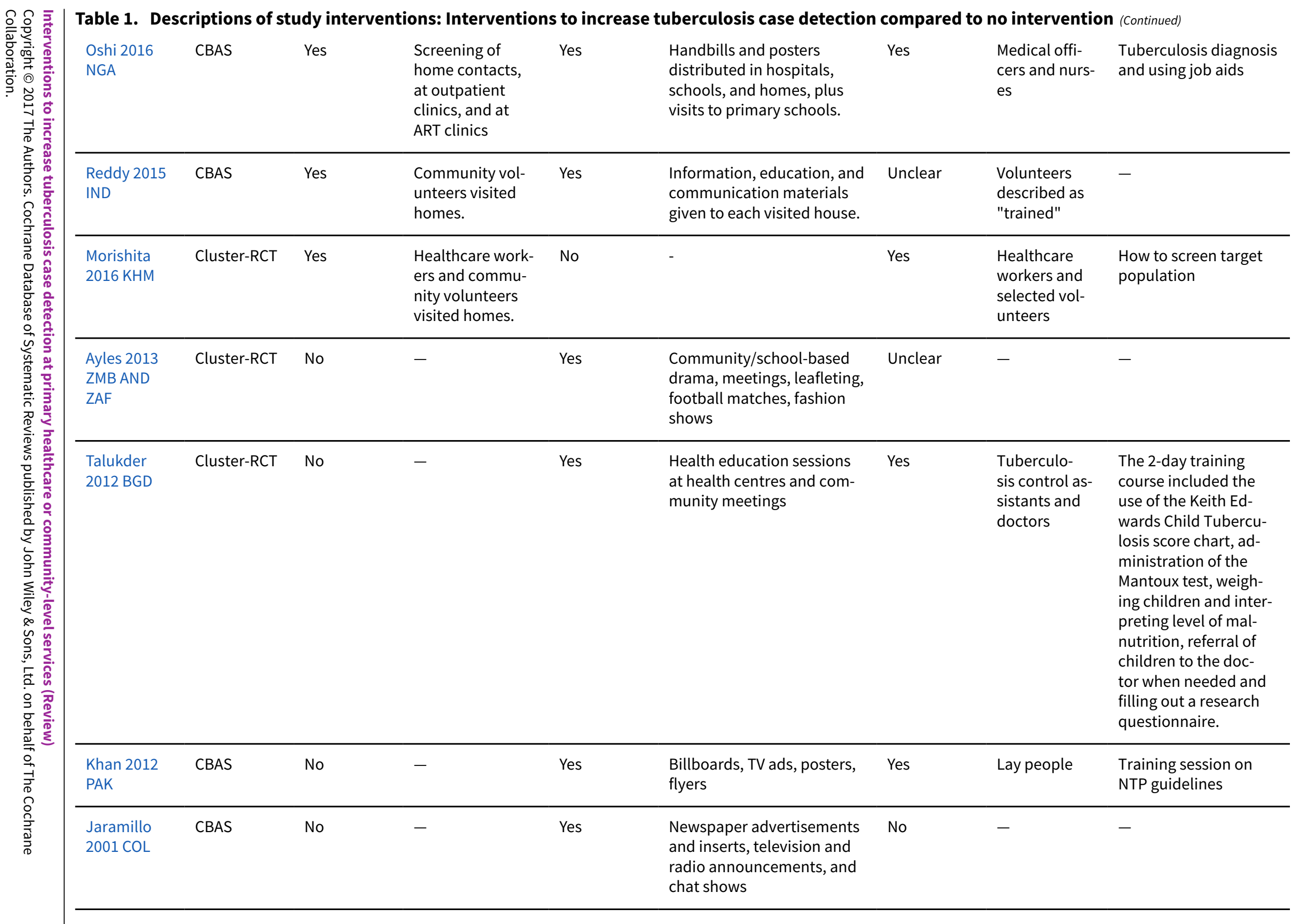




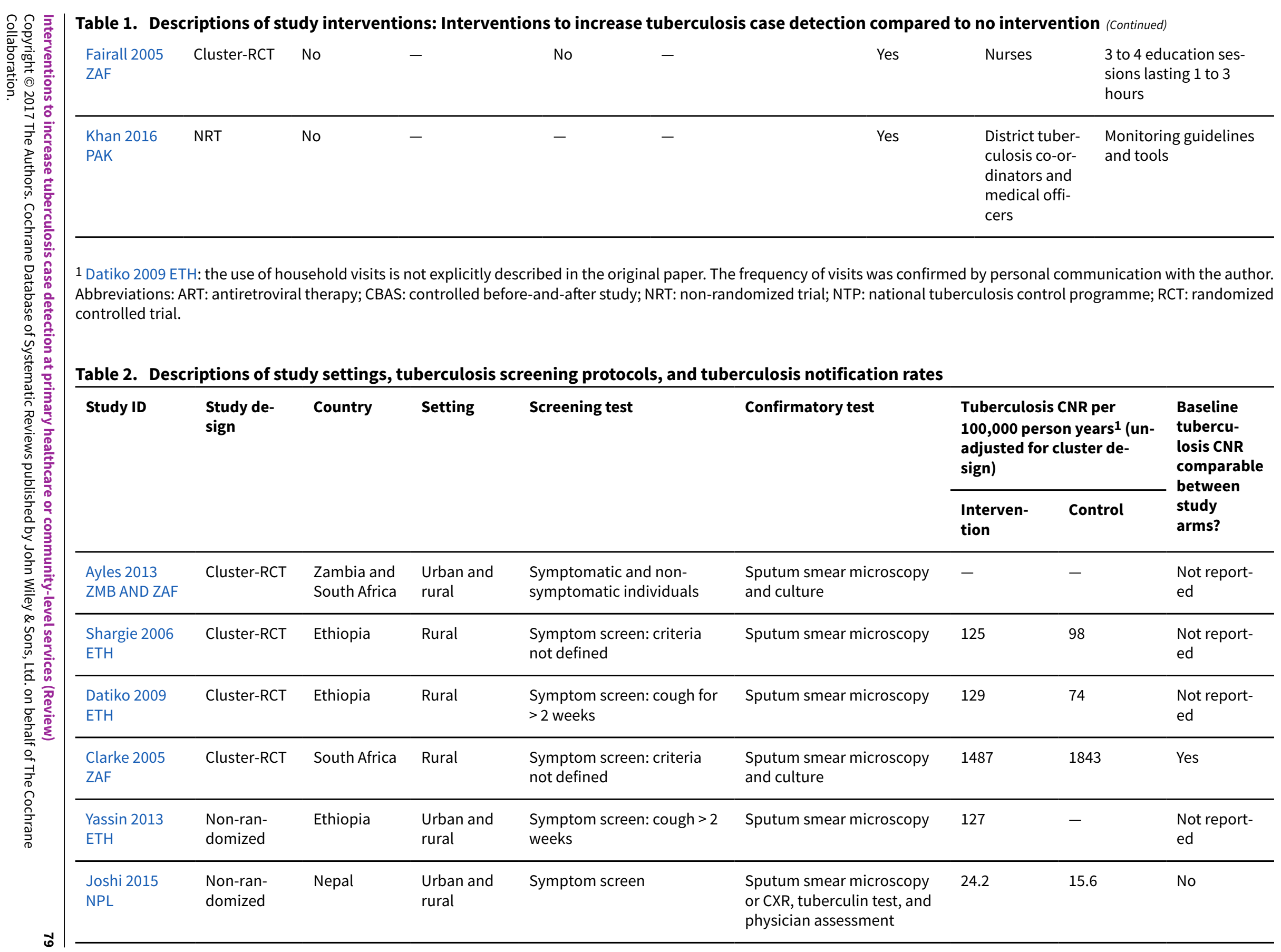

Table 2. Descriptions of study settings, tuberculosis screening protocols, and tuberculosis notification rates 


\begin{tabular}{|c|c|c|c|c|c|c|c|c|}
\hline 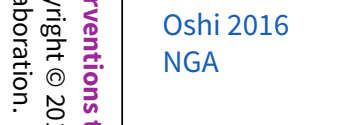 & $\begin{array}{l}\text { Non-ran- } \\
\text { domized }\end{array}$ & Nigeria & $\begin{array}{l}\text { Urban and } \\
\text { rural }\end{array}$ & Symptom screen & $\begin{array}{l}\text { Sputum smear microscopy } \\
\text { or Keith Edwards Tubercu- } \\
\text { losis score chart }\end{array}$ & - & - & $\begin{array}{l}\text { Not report- } \\
\text { ed }\end{array}$ \\
\hline $\begin{array}{l}\text { Reddy } 2015 \\
\text { IND }\end{array}$ & $\begin{array}{l}\text { Non-ran- } \\
\text { domized }\end{array}$ & India & $\begin{array}{l}\text { Urban and } \\
\text { rural }\end{array}$ & Unclear & Sputum smear microscopy & - & - & $\begin{array}{l}\text { Not report- } \\
\text { ed }\end{array}$ \\
\hline $\begin{array}{l}\text { Talukder } 2012 \\
\text { BGD }\end{array}$ & Cluster-RCT & Bangladesh & $\begin{array}{l}\text { Urban and } \\
\text { rural }\end{array}$ & None described. & $\begin{array}{l}\text { Keith Edwards Child Tuber- } \\
\text { culosis Score Chart }\end{array}$ & - & - & $\begin{array}{l}\text { Not report- } \\
\text { ed }\end{array}$ \\
\hline $\begin{array}{l}\text { Khan } 2012 \\
\text { PAK }\end{array}$ & $\begin{array}{l}\text { Non-ran- } \\
\text { domized }\end{array}$ & Pakistan & Urban & $\begin{array}{l}\text { Symptom screen: cough > } 3 \\
\text { weeks or productive cough } \\
>2 \text { weeks }\end{array}$ & $\begin{array}{l}\text { Sputum smear microscopy, } \\
\text { GeneXpert, or CXR }\end{array}$ & 343 & 41 & No \\
\hline $\begin{array}{l}\text { Jaramillo } \\
2001 \mathrm{COL}\end{array}$ & $\begin{array}{l}\text { Non-ran- } \\
\text { domized }\end{array}$ & Colombia & Urban & None described. & Sputum smear microscopy & - & - & $\begin{array}{l}\text { Not report- } \\
\text { ed }\end{array}$ \\
\hline 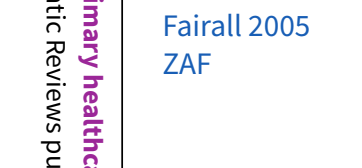 & Cluster-RCT & South Africa & $\begin{array}{l}\text { Urban and } \\
\text { rural }\end{array}$ & $\begin{array}{l}\text { Symptom screen: criteria } \\
\text { not defined }\end{array}$ & $\begin{array}{l}\text { Sputum smear microscopy } \\
\text { and culture/CXR, clinical } \\
\text { diagnosis (evidence-treat- } \\
\text { ment card) }\end{array}$ & - & - & $\begin{array}{l}\text { Not report- } \\
\text { ed }\end{array}$ \\
\hline $\begin{array}{l}\text { Corbett } 2010 \\
\text { ZWE }\end{array}$ & Cluster-RCT & Zimbabwe & Urban & $\begin{array}{l}\text { Symptom screen: cough for } \\
>2 \text { weeks }\end{array}$ & $\begin{array}{l}\text { Sputum smear microscopy } \\
\text { and culture }\end{array}$ & 427 & 380 & Yes \\
\hline $\begin{array}{l}\text { Miller } 2010 \\
\text { BRA }\end{array}$ & Cluster-RCT & Brazil & Urban & $\begin{array}{l}\text { Symptom screen: cough for } \\
>3 \text { weeks }\end{array}$ & Sputum smear $x 2$ plus CXR & 934 & 604 & Yes \\
\hline 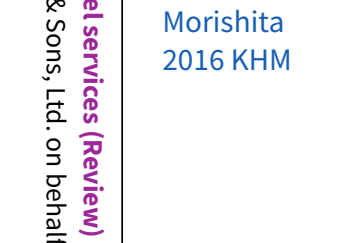 & Cluster-RCT & Cambodia & $\begin{array}{l}\text { Urban and } \\
\text { rural }\end{array}$ & $\begin{array}{l}\text { Symptoms screening: } \\
\text { cough, fever, weight loss, } \\
\text { and/or night sweats of } \\
\text { more than } 2 \text { weeks and } \\
\text { household contacts without } \\
\text { symptoms }\end{array}$ & Gene Xpert MTB/RIF & 323 & 254 & Yes \\
\hline $\begin{array}{l}\text { Moyo } 2012 \\
\text { ZAF }\end{array}$ & $\begin{array}{l}\text { Individ- } \\
\text { ual-RCT }\end{array}$ & South Africa & Urban & $\begin{array}{l}\text { Tuberculosis symptom } \\
\text { screening and tuberculosis } \\
\text { contact }\end{array}$ & $\begin{array}{l}\text { Sputum smear microscopy } \\
\text { and culture }\end{array}$ & - & - & - \\
\hline
\end{tabular}

1The tuberculosis case notification rate (CNR) was calculated by dividing the total number of tuberculosis cases by the duration of the trial (in years), then dividing by the population of the intervention area and multiplying by 100,000 .

Abbreviations: CNR: case notification rate; CXR: chest X-ray. 
Table 3. Primary tuberculosis case-finding outcome for studies of tuberculosis outreach diagnostic services

\begin{tabular}{|c|c|c|c|c|c|c|c|}
\hline Study ID & Study design & Outcome measure & Intervention & Control & $\begin{array}{l}\text { Effect esti- } \\
\text { mate } \\
(95 \% \mathrm{CI})\end{array}$ & $\begin{array}{l}\text { Adjusted for } \\
\text { cluster de- } \\
\text { sign }\end{array}$ & Comment \\
\hline $\begin{array}{l}\text { Ayles } 2013 \\
\text { ZMB AND ZAF }\end{array}$ & Cluster-RCT & - & - & - & - & NA & $\begin{array}{l}\text { Tuberculosis case detection } \\
\text { is not reported. The primary } \\
\text { outcome is long-term tuber- } \\
\text { culosis prevalence. }\end{array}$ \\
\hline $\begin{array}{l}\text { Shargie } 2006 \\
\text { ETH }\end{array}$ & Cluster-RCT & $\begin{array}{l}\text { Tuberculosis case notification rate } \\
\text { per } 100,000 \text { person years during } \\
\text { the intervention }\end{array}$ & 125 & 98 & $\begin{array}{l}\text { Difference } 27 \\
\text { (-19 to } 72)\end{array}$ & Yes & $\begin{array}{l}P=0.12 \\
I C C=0.00027\end{array}$ \\
\hline $\begin{array}{l}\text { Datiko } 2009 \\
\text { ETH }\end{array}$ & Cluster-RCT & $\begin{array}{l}\text { Tuberculosis case detection rate as } \\
\text { a percentage of the average annual } \\
\text { case detection rate }\end{array}$ & $122.2 \%$ & $69.4 \%$ & $\begin{array}{l}\text { Difference } \\
\mathbf{5 2 . 4 \%} \\
\text { (39.8 to } 65.4)\end{array}$ & Yes & $\begin{array}{l}\mathrm{P}<0.001 \\
\mathrm{ICC}=0.00052\end{array}$ \\
\hline $\begin{array}{l}\text { Clarke } 2005 \\
\text { ZAF }\end{array}$ & Cluster-RCT & $\begin{array}{l}\text { The number of clusters with high- } \\
\text { er case finding during the interven- } \\
\text { tion period }\end{array}$ & $26 / 106$ & $18 / 105$ & $\begin{array}{l}\text { Difference } \\
\mathbf{8 . 9 \%} \\
(-0.7 \text { to } 24.9)\end{array}$ & NA & $P=0.29$ \\
\hline $\begin{array}{l}\text { Yassin } 2013 \\
\text { ETH }\end{array}$ & $\begin{array}{l}\text { Non-random- } \\
\text { ized }\end{array}$ & $\begin{array}{l}\text { Tuberculosis case notification rate } \\
\text { per } 100,000 \text { person years }\end{array}$ & 127 & - & - & NA & $\begin{array}{l}\text { Only the intervention area } \\
\text { data are presented as a be- } \\
\text { fore-and-after analysis. No } \\
\text { statistical significance test- } \\
\text { ing was done. }\end{array}$ \\
\hline $\begin{array}{l}\text { Joshi } 2015 \\
\text { NPL }\end{array}$ & $\begin{array}{l}\text { Non-random- } \\
\text { ized }\end{array}$ & $\begin{array}{l}\text { Change in childhood tuberculosis } \\
\text { case notification per } 100,000 \text { com- } \\
\text { pared to previous year }\end{array}$ & $+6 \%$ & $+2.2 \%$ & $\begin{array}{l}\text { Difference } \\
\mathbf{3 . 8} \% \\
(2.7 \text { to } 5.2)\end{array}$ & NA & $P<0.001$ \\
\hline $\begin{array}{l}\text { Oshi } 2016 \\
\text { NGA }\end{array}$ & $\begin{array}{l}\text { Non-random- } \\
\text { ized }\end{array}$ & $\begin{array}{l}\text { Change in tuberculosis cases iden- } \\
\text { tified }\end{array}$ & $+31 \%$ & Not stated & Not stated & NA & $\begin{array}{l}\text { Only data from the interven- } \\
\text { tion areas are presented. }\end{array}$ \\
\hline $\begin{array}{l}\text { Reddy } 2015 \\
\text { IND }\end{array}$ & $\begin{array}{l}\text { Non-random- } \\
\text { ized }\end{array}$ & $\begin{array}{l}\text { Change in number of smear-posi- } \\
\text { tive tuberculosis cases compared } \\
\text { to previous year }\end{array}$ & $+8.8 \%$ & $-8.6 \%$ & - & NA & $\begin{array}{l}\text { Only the number of cases } \\
\text { detected is presented, with- } \\
\text { out denominators. }\end{array}$ \\
\hline
\end{tabular}


Abbreviations: Cl: confidence interval; ICC: intraclass correlation coefficient; NA: not applicable; RCT: randomized controlled trial.

Table 4. Primary tuberculosis case-finding outcome for studies of health promotion

\begin{tabular}{|c|c|c|c|c|c|c|c|}
\hline Study ID & Study design & $\begin{array}{l}\text { Outcome mea- } \\
\text { sure }\end{array}$ & Intervention & Control & $\begin{array}{l}\text { Effect estimate } \\
(95 \% \mathrm{Cl})\end{array}$ & $\begin{array}{l}\text { Adjusted for } \\
\text { cluster de- } \\
\text { sign }\end{array}$ & Comment \\
\hline $\begin{array}{l}\text { Ayles } 2013 \\
\text { ZMB AND ZAF }\end{array}$ & Cluster-RCT & - & - & - & - & NA & $\begin{array}{l}\text { Tuberculosis case detection was not re- } \\
\text { ported. The primary outcome was long- } \\
\text { term tuberculosis prevalence. }\end{array}$ \\
\hline $\begin{array}{l}\text { Talukder } 2012 \\
\text { BGD }\end{array}$ & Cluster-RCT & $\begin{array}{l}\text { Number of tu- } \\
\text { berculosis cas- } \\
\text { es diagnosed }\end{array}$ & 175 & 130 & $\begin{array}{l}\text { No significance test- } \\
\text { ing was done be- } \\
\text { tween intervention } \\
\text { and control areas. }\end{array}$ & NA & $\begin{array}{l}\text { The number of tuberculosis cases diag- } \\
\text { nosed in the intervention area was high- } \\
\text { er during the intervention compared to } \\
\text { pre-intervention ( } P=0.001 \text {. }\end{array}$ \\
\hline $\begin{array}{l}\text { Khan } 2012 \\
\text { PAK }\end{array}$ & $\begin{array}{l}\text { Non-random- } \\
\text { ized }\end{array}$ & $\begin{array}{l}\text { Tuberculosis } \\
\text { case detection } \\
\text { per } 100,000\end{array}$ & 343 & 41 & $\begin{array}{l}\text { No significance test- } \\
\text { ing was done be- } \\
\text { tween intervention } \\
\text { and control areas. }\end{array}$ & NA & $\begin{array}{l}\text { The tuberculosis case notification in the } \\
\text { intervention area increased } 2 \text {-fold dur- } \\
\text { ing the intervention }(P=0.000) \text {. }\end{array}$ \\
\hline $\begin{array}{l}\text { Jaramillo } \\
2001 \text { COL }\end{array}$ & $\begin{array}{l}\text { Non-random- } \\
\text { ized }\end{array}$ & $\begin{array}{l}\text { Number of tu- } \\
\text { berculosis cas- } \\
\text { es/number of } \\
\text { people tested }\end{array}$ & - & - & $\begin{array}{l}\text { No significance test- } \\
\text { ing was done be- } \\
\text { tween intervention } \\
\text { and control areas. }\end{array}$ & NA & $\begin{array}{l}\text { A temporal association is noted be- } \\
\text { tween the number of people being test- } \\
\text { ed and the intervention. There is not a } \\
\text { convincing corresponding increase in } \\
\text { the number of new tuberculosis diag- } \\
\text { noses. }\end{array}$ \\
\hline
\end{tabular}

Abbreviations: $\mathrm{Cl}$ : confidence interval; NA: not applicable; RCT: randomized controlled trial

Table 5. Tuberculosis case-finding outcome for studies of health staff training in tuberculosis diagnosis

\begin{tabular}{|c|c|c|c|c|c|c|c|}
\hline Study ID & Study design & Outcome measure & Intervention & Control & $\begin{array}{l}\text { Effect estimate } \\
(95 \% \mathrm{Cl})\end{array}$ & $\begin{array}{l}\text { Adjusted for } \\
\text { cluster de- } \\
\text { sign }\end{array}$ & Comment \\
\hline $\begin{array}{l}\text { Fairall } 2005 \\
\text { ZAF }\end{array}$ & Cluster-RCT & $\begin{array}{l}\text { New tuberculosis cases detected per } \\
1000 \text { patients }\end{array}$ & 57 & 34 & $\begin{array}{l}\text { Odds ratio } \mathbf{1 . 7 2} \\
\text { (1.04 to } 2.85)\end{array}$ & Yes & $\begin{array}{l}P=0.04 \\
I C C=0.007\end{array}$ \\
\hline
\end{tabular}




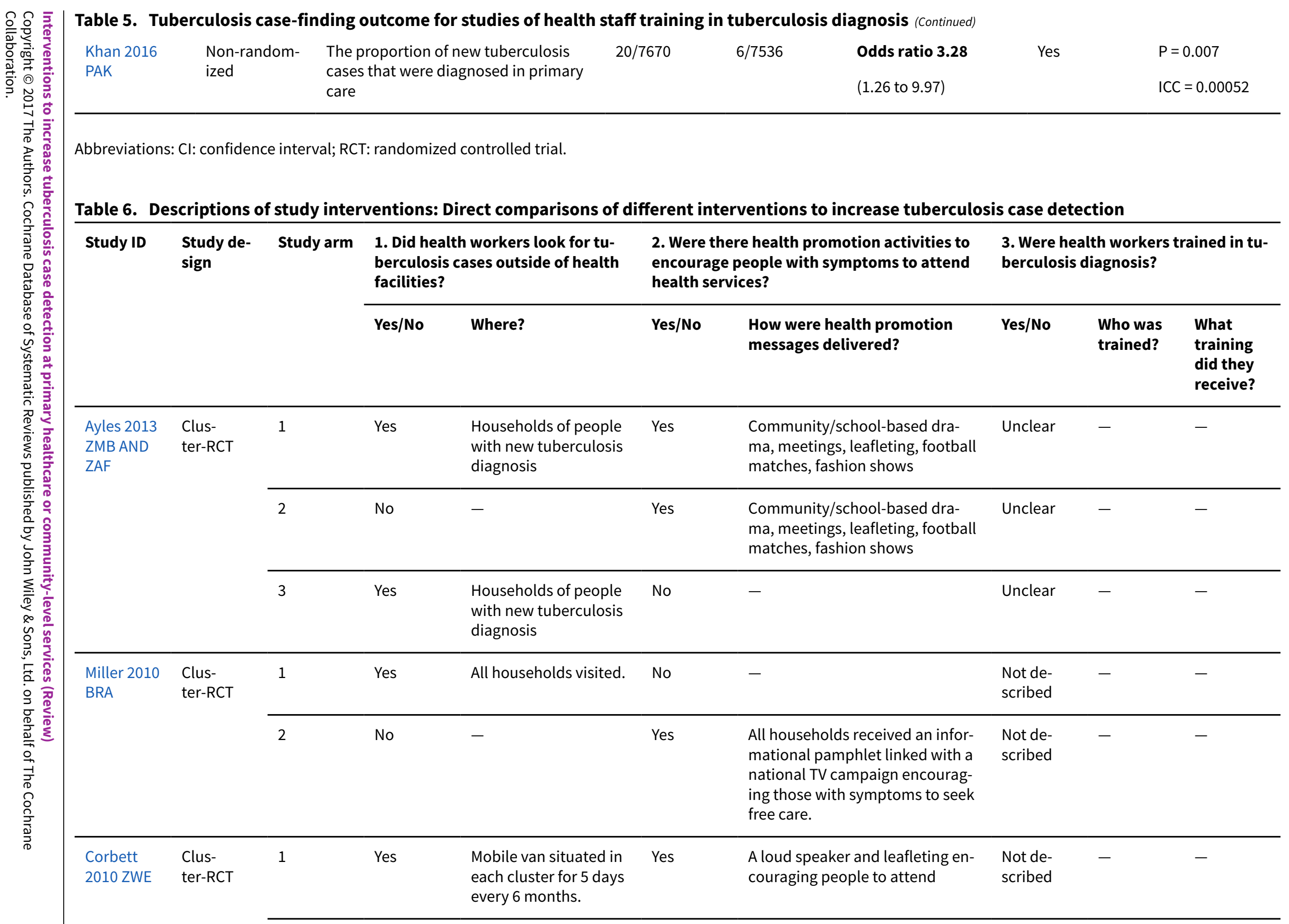




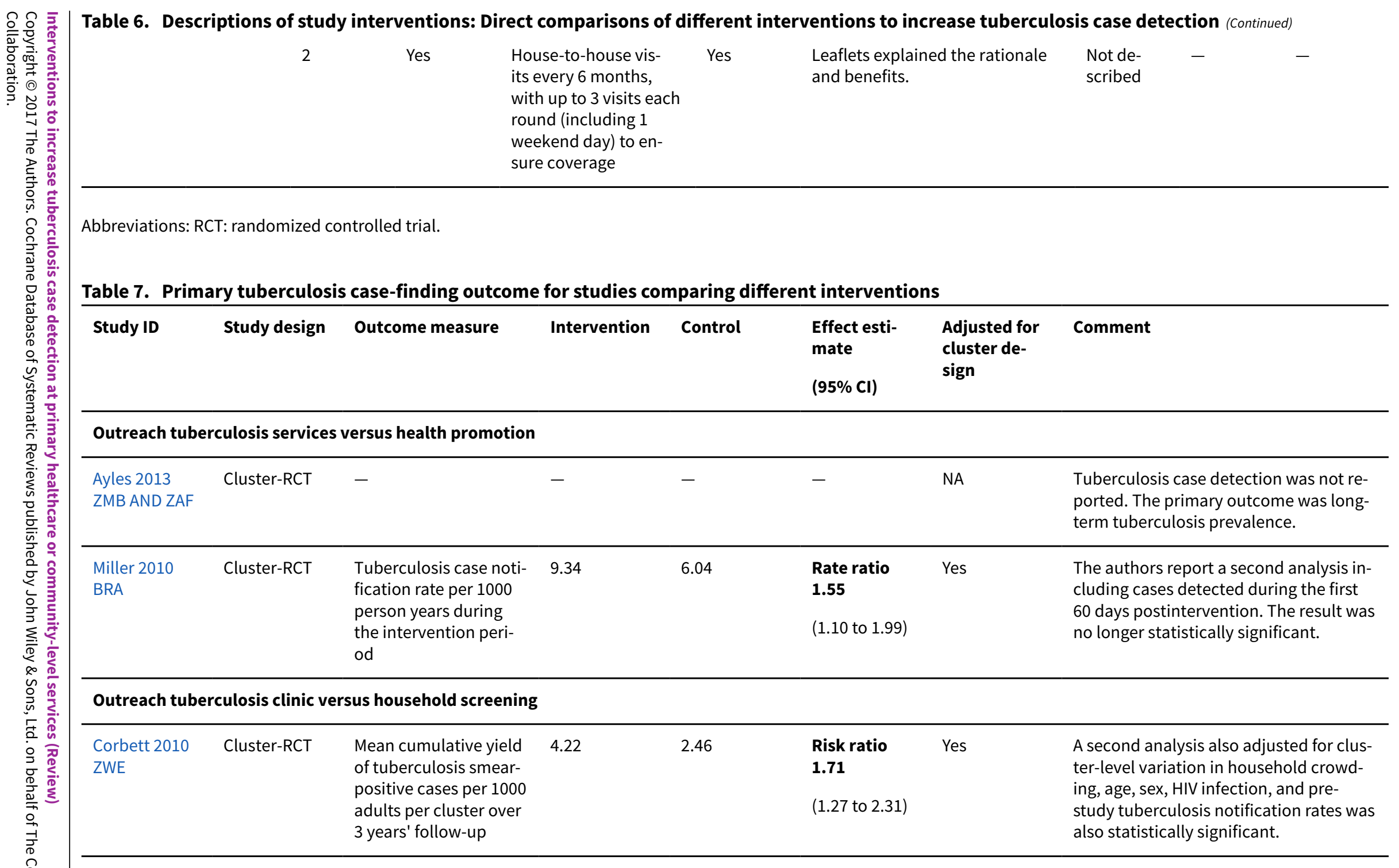

Abbreviations: $\mathrm{Cl}$ : confidence interval; NA: not applicable; RCT: randomized controlled trial. 


\section{APPENDICES}

\section{Appendix 1. Search strategy}

\begin{tabular}{|c|c|}
\hline Search set & Embase \\
\hline 1 & Tuberculosis [Emtree] \\
\hline 2 & Tuberculosis [ti, ab] \\
\hline 3 & Mycobacterium tuberculosis [Emtree] \\
\hline 4 & Case $^{\star}$ detection ti, ab \\
\hline 5 & Case $^{\star}$ finding ti, ab \\
\hline 6 & Systematic screening ${ }^{\star} \mathrm{ti}, \mathrm{ab}$ \\
\hline 7 & Case finding [Emtree] \\
\hline 8 & 1 or 2 or 3 \\
\hline 9 & 4 or 5 or 6 or 7 \\
\hline 10 & Diagnos $^{\star}$ OR detect ${ }^{\star}$ OR screen ${ }^{\star}$ OR assess $s^{\star} t i, a b$ \\
\hline 11 & 8 and 9 and 10 \\
\hline
\end{tabular}

\begin{tabular}{ll}
\hline Search set & MEDLINE \\
\hline 1 & tuberculosis [MeSH] \\
\hline 2 & tuberculosis [ti, ab ] \\
\hline 3 & Mycobacterium tuberculosis [MeSH] \\
\hline 4 & Case* detection ti, ab \\
\hline 5 & Case* finding ti, ab \\
\hline 6 & Systematic screening ${ }^{\star}$ ti, ab \\
\hline 7 & 1 or 2 or 3 \\
\hline 9 & 4 or 5 or 6 \\
\hline 10 & Diagnos* OR detect* OR screen* OR assess* ti, ab \\
\hline 11 & 7 and 8 and 9 \\
\hline
\end{tabular}




\section{The Cochrane Library}

$\# 1$ tuberculosis

\#2 MeSH descriptor: [Tuberculosis] explode all trees

\#3 MeSH descriptor: [Mycobacterium tuberculosis] explode all trees

\#4 \#1 or \#2 or \#3

\#5 "case detection" or "case finding" or "systematic screening"

\#6 \#4 and \#5

\section{Web of Science Core Collection}

You searched for: TOPIC: (tuberculosis) AND TOPIC: ((case finding) OR (case detection) OR (systematic screening)) AND TOPIC: (diagnos ${ }^{\star}$ OR detect ${ }^{\star}$ OR screen ${ }^{\star}$ OR assess) AND TOPIC: (intervention* OR program ${ }^{\star}$ OR community OR random ${ }^{\star}$ OR trial* OR before) ...MoreTOPIC: (tuberculosis) AND TOPIC: ((case finding) OR (case detection) OR (systematic screening)) AND TOPIC: (diagnos ${ }^{\star}$ OR detect $^{\star}$ OR screen* OR assess) AND TOPIC: (intervention* OR program OR community OR random OR trial* OR before)

Indexes: SCI-EXPANDED, SSCI,

\section{BIOSIS Previews}

You searched for: TOPIC: (tuberculosis OR TB) AND TOPIC: ((case finding) OR (case detection) OR (systematic screening)) AND TOPIC: ((intervention* OR program* OR community OR random* OR trial* OR before)) ...More TOPIC:(tuberculosis OR TB) AND TOPIC:((case finding) OR (case detection) OR (systematic screening)) AND TOPIC: ((intervention* OR program OR community OR random ${ }^{\star} \mathrm{OR}^{\star}$ trial ${ }^{\star}$ OR before))

Indexes: BIOSIS Previews.

\section{Scopus}

( TITLE-ABS-KEY ( tuberculosis ) AND TITLE-ABS-KEY ( ( case detection ) OR ( case finding ) OR ( systematic screening ) ) AND TITLE-ABSKEY ( intervent ${ }^{\star}$ OR program* OR initiative OR trial* OR random* OR before) ) AND SUBJAREA ( mult OR agri OR bioc OR immu OR neur OR phar OR mult OR medi OR nurs OR vete OR dent OR heal OR mult OR arts OR busi OR deci OR econ OR psyc OR soci ) AND ( LIMIT-TO ( SUBJAREA, "MEDI" ))

\section{CONTRIBUTIONS OF AUTHORS}

All review authors jointly developed the protocol and provided comments and feedback. FM, AM, and DS performed data extraction and analysis, and all authors wrote the manuscript. All authors agreed on the content of the final review and its submission for publication.

\section{DECLARATIONS OF INTEREST}

Francis A Mhimbira has no conflicts of interest to declare.

Professor Luis Cuevas has received seven awards from the TB REACH programme of the Stop TB Partnership. This programme aims to increase tuberculosis case detection in low-income countries, which often includes community-based interventions, which is the focus of the current review.

Russell Dacombe was part-funded by a European \& Developing Countries Clinical Trials Partnership grant (TB-NEAT, IP.2009.32040.009) which included support to the preparation of this review.

Abdallah Mkopi has no conflicts of interest to declare

David Sinclair: was supported as an author and editor with the Cochrane Infectious Diseases Group by the Effective Health Care Research Consortium.

\section{SOURCES OF SUPPORT}

\section{Internal sources}

- Liverpool School of Tropical Medicine, UK.

- Cochrane South Africa, South Africa.

- South African Medical Research Council, South Africa.

- European \& Developing Countries Clinical Trials Partnership, Netherlands.

Grant (TB-NEAT, IP.2009.32040.009) 


\section{External sources}

- Department for International Development (DFID), UK.

Grant: 5242

\section{DIFFERENCES BETWEEN PROTOCOLANDREVIEW}

The following are the changes between the protocol and the review.

- We changed "additional tuberculosis cases starting treatment" to "tuberculosis cases detected (all forms)".

- We changed "additional tuberculosis cases detected (microbiologically confirmed)" to "tuberculosis cases detected".

- Primary outcome: We used "tuberculosis cases detected (microbiologically confirmed)" instead of "tuberculosis cases detected (all forms)".

\section{N DEX TERMS}

\section{Medical Subject Headings (MeSH)}

${ }^{*}$ Community Health Services; *Patient Acceptance of Health Care; *Primary Health Care; Early Diagnosis; Non-Randomized Controlled Trials as Topic; Prevalence; Program Evaluation; Randomized Controlled Trials as Topic; Tuberculosis, Pulmonary [ ${ }^{\star}$ diagnosis] [drug therapy] [mortality]

\section{MeSH check words}

Humans 